\author{
Universidade de São Paulo \\ Faculdade de Educação \\ Programa de Pós-Graduação
}

\title{
A MÚSICA E A CONSTRUÇÃO DO CONHECIMENTO HISTÓRICO EM AULA
}

Tese apresentada como exigência parcial para a obtenção do título de doutor em educação pelo Programa de Pós-Graduação em Educação da Faculdade de Educação da Universidade de São Paulo (FE/USP)

Área de concentração: Educação

Área temática: Didática, Teorias de Ensino e Práticas Escolares

Aluno: Milton Joeri Fernandes Duarte

Orientadora: Profa. Dra. Kátia Maria Abud

\section{São Paulo}


Autorizo a reprodução e divulgação total ou parcial deste trabalho, por qualquer meio convencional ou eletrônico, para fins de estudo e pesquisa, desde que citada a fonte.

Catalogação na Publicação

Serviço de Biblioteca e Documentação

Faculdade de Educação da Universidade de São Paulo

\section{$375.42 \quad$ Duarte, Milton Joeri Fernandes}

D812m A música e a construção do conhecimento histórico em aula / Milton Joeri

Fernandes Duarte ; orientação Kátia Maria Abud. São Paulo : s.n., 2011.

$170 \mathrm{p}$ : il., tabs.

Tese (Doutorado - Programa de Pós-Graduação em Educação. Área de Concentração : Didática, Teorias de Ensino e Práticas Escolares) - Faculdade de Educação da Universidade de São Paulo)

1. História - Estudo e ensino 2. Linguagem musical - História 3. Construção do conhecimento - História I. Abud, Kátia Maria, orient. 
Para a minha esposa Noeli e a minha filha Maria Cecília, as principais notas musicais da melodia motivadora que compõe a trajetória deste trabalho. 
"A música é percebida única e exclusivamente em e mediante o tempo, com inteira exclusão do espaço, sem influência do conhecimento da casualidade, e portanto do entendimento" (Schopenhauer)

"Depois do silêncio, aquilo que mais aproximadamente exprime o inexprimível é a música." (Aldous Huxley)

"Não sei uma nota de música. Nem preciso." (Elvis Presley)

"Sem música para decorar, tempo é só a monotonia de prazos de entregas e contas à pagar." (Frank Zappa) 
RESUMO__ 6

ABSTRACT

AGRADECIMENTOS__ 8

INTRODUÇÃO__ 9

CAPÍTULO 1- MÚSICA E CULTURA ESCOLAR: ESCUTA INDIVIDUALIZADA, INEXPRESSÃO CORPORAL E CULTURA DO SILÊNCIO___ 30

CAPÍTULO 2- A MÚSICA COMO LINGUAGEM AFETIVA TRANSFORMADA EM CONSCIÊNCIA

CAPÍTULO 3- A MEDIAÇÃO CULTURAL E A “PAISAGEM SONORA” DA SALA DE AULA

CAPÍTULO 4- AS INFLUÊNCIAS DA LINGUAGEM MUSICAL NAS

REPRESENTAÇÕES E NA CONSCIÊNCIA HISTÓRICA DOS ALUNOS 75

CAPÍTULO 5- O CONHECIMENTO E O SABER-FAZER DO PROFESSOR NA APLICAÇÃO DA LINGUAGEM MUSICAL COMO LEGITIMADORES DE UMA PRÁTICA PEDAGÓGICA NO CAMPO ESCOLAR

CAPÍTULO 6- A MEMÓRIA E A CONSCIÊNCIA HISTÓRICA DO SABER-

FAZER DO PROFESSOR NA APLICAÇÃO DA LINGUAGEM

MUSICAL 105 CONSIDERAÇÕES FINAIS 117

APÊNDICES

ANEXOS 140

BIBLIOGRAFIA 148 PÁGINAS ELETRÔNICAS 


\section{RESUMO}

O principal objetivo desta pesquisa foi demonstrar a importância da música para a construção do conhecimento histórico de alunos e professores. A consciência histórica mediada pela linguagem musical revela uma forte carga afetiva, pois faz parte de uma memória pessoal e modelo de referência para a apreensão e assimilação das novas audições, similares ou não as anteriores, revelando assim o que podemos chamar de consciência musical dos sujeitos envolvidos. A importância da música em sala de aula encontra-se principalmente relacionada à própria natureza da linguagem musical, pois só pode ser percebida única e exclusivamente em e mediante o tempo, alimentando-se de uma memória afetiva que se transforma em uma consciência musical no presente, facilitando as narrativas, reflexões, práticas ou interpretações históricas dos alunos e da professora.

PALAVRAS-CHAVE: Conhecimento histórico, consciência histórica, linguagem musical, memória e consciência musical. 


\begin{abstract}
The main objective of this research was to demonstrate the importance of music to building historical knowledge in students and teachers. The historical awareness mediated by musical language reveals a strong affective load, because it is part of a personal memory and a reference to the apprehension and assimilation of new listening, similar or not to the ones mentioned before, revealing what we can call musical awareness of the involved subjects. The importance of music in class is mainly related to the nature of the musical language itself, as this can only be noticed in and through time, feeding itself from an affective memory that transforms itself in a musical awareness in the present, facilitating the narratives, reflexions, practices or historical interpretations of the students and the teacher.
\end{abstract}

KEY WORDS: Historical knowledge, historical awareness, musical language, memory and musical awareness. 


\section{AGRADECIMENTOS}

Gostaria de agradecer as pessoas que tornaram possível a conclusão desta pesquisa. À Profa. Dra. Kátia Maria Abud, pela sua orientação, amizade e apoio ao longo de todos esses anos. Aos professores do programa de Pós-Graduação da Faculdade de Educação da USP e, em especial, à Profa. Dra. Belmira Amélia de Barros Oliveira Bueno, pelas orientações em relação ao trabalho de campo. Aos professores Marcos Silva e Leny Magalhães Mrech pelas críticas e contribuições feitas no Exame de Qualificação. Aos funcionários, alunos e professores da E.M.E.F. Tenente José Maria Pinto Duarte e, em especial, à Profa. Marli Oliveira de Carvalho, que sem a sua colaboração e gentileza este trabalho não seria possível. À direção, funcionários e professores do Colégio Marista de São Paulo e, em especial, aos colegas de profissão que colaboraram direta e indiretamente para a conclusão deste trabalho: Profo. Murilo Resende, Profo. Ronaldo Cardoso Alves, Profa. Silvana Santos e Profa. Vanessa Fernadez Panocca. 


\section{INTRODUÇÃO}

A escolha e o desenvolvimento do tema A Música e a Construção do Conhecimento Histórico em Aula têm origem, em um primeiro momento, na organização e no desenvolvimento de um curso temático intitulado "Movimentos culturais de juventude" para alunos do Ensino Médio da rede pública do período noturno (ano letivo de 1988), cujo principal objetivo era motivá-los para as aulas, fazendo-os sentir a importância do jovem no processo histórico contemporâneo da segunda metade do século XX. O curso acabou se transformando posteriormente em um livro paradidático: "Movimentos culturais de juventude" (Coleção Polêmica), Ed. Moderna, 1990.

O segundo momento, que evidencia essa importância da música na construção do conhecimento histórico, foi durante a minha dissertação de mestrado intitulada "Representações dos movimentos político-culturais da década de 60 nos jovens de Ensino Médio", nessa mesma área temática, que teve como principal objetivo identificar e comparar as representações históricas dos movimentos político-culturais dos anos 60 com as representações utilizadas pelos alunos do Ensino Médio para entender esses movimentos. O trabalho procurou mostrar as informações e representações sobre os movimentos jovens da década de 60 presentes no conhecimento histórico dos estudantes, quando eram utilizadas músicas significativas do período como provas projetivas ${ }^{1}$ durante as entrevistas.

Portanto, incentivado pelas experiências anteriores, esta pesquisa tem como objetivo estudar o processo de construção do conhecimento histórico dos alunos e do professor através da música, inserida no contexto de uma cultura escolar, para que possamos compreender até que ponto a linguagem musical pode ou não interferir na construção do conhecimento histórico em aula.

No caso da cultura escolar, esta pesquisa estabeleceu alguns pontos de reflexão sobre a relação entre música e cultura escolar a partir das observações ligadas às atividades de campo envolvendo seus agentes no processo de aprendizagem, que, no nosso caso, seria mediado pela linguagem musical. Portanto, um importante ponto de reflexão desta pesquisa é de como

\footnotetext{
${ }^{1}$ As entrevistas gravadas em fitas cassete foram direcionadas através de um roteiro pré-estabelecido e de provas projetivas (fotos e músicas significativas dos anos 60). Com isso, o sujeito foi colocado diante de situações pouco estruturadas mediante a utilização de símbolos que não pertencem ao seu tempo, sendo obrigado a fazer comentários através de um roteiro de perguntas formulado pelo pesquisador, a que chamamos de provas projetivas (POSTIC, 1993: 52).
} 
as práticas pedagógicas mediadas pela música podem ou não interferir e transformar a cultura escolar.

Já as representações históricas construídas por alunos e professora incentivadas pela música foram estudadas de maneira diagnóstica, através de uma pesquisa de inspiração etnográfica de observação e entrevistas. Procurou-se identificar as relações estabelecidas pelos sujeitos entre a realidade atual e o passado histórico, formando, assim, a chamada consciência histórica.

Mediada pela linguagem musical, essa consciência histórica possui uma forte carga afetiva elaborada pelos alunos e pela professora, transformando-se em memória pessoal e modelo de referência para a apreensão e assimilação das novas audições, similares ou não às anteriores, revelando assim o que podemos chamar de consciência musical dos sujeitos envolvidos. Portanto, questões essenciais deverão ser respondidas por esta pesquisa, entre elas, como se forma essa consciência musical? E qual a importância dela na formação da consciência histórica e na construção do conhecimento histórico de alunos e professor?

As experiências do passado representam, no relato dos entrevistados, mais que a matéria-prima bruta de histórias produzidas para fazer sentido. Trata-se de algo que já possui, em si, a propriedade de estar dotado de sentido, de modo que a constituição consciente de sentido da narrativa histórica se refere diretamente a ela e lhe dá continuação, engendrando vários ingredientes das operações conscientes do pensamento histórico.

O passado passa a ser articulado, como estado de coisas, com as orientações presentes no agir contemporâneos dos alunos e da professora. Assim, as representações históricas dessas narrativas têm de ser pensadas como algo que emerge de determinados processos da vida prática desses sujeitos que fazem parte dos processos de constituição de sentido estabelecido pela consciência histórica.

A consciência histórica é, antes de tudo, uma mediação entre os valores morais (orientadores de comportamento) e a ação dos alunos e da professora dentro e fora do ambiente escolar. A maior parte das representações dos entrevistados, durante esta pesquisa, demonstrou a necessidade da consciência histórica para tratarem de valores morais e de argumentação moral (razão) e de como essa consciência pode ser estimulada pela linguagem musical. 


\section{A linguagem musical e suas dimensões histórico-pedagógicas}

A música não é apenas uma combinação de notas dentro de uma escala, mas também ruídos de passos e bocas, sons eletrônicos, ou ainda uma vestimenta e gestos do cotidiano de determinados indivíduos que gostam de um tipo de som. É tudo isso e mais o produto de longas e incontáveis vivências coletivas e individuais com as experiências de civilizações diversas ao longo da história. Dessa forma, a música como fenômeno cultural e social apresenta várias facetas concretas e abstratas que estimulam várias representações sobre a linguagem musical e que, necessariamente, demandam uma integração teórica e metodológica de várias áreas do conhecimento.

“(...) o antropólogo americano Alan P. Merriam formulou uma 'teoria da etnomusicologia', na qual reforçou a necessidade da integração dos métodos de pesquisa musicológicos e antropológicos. Música é definida por Merriam como um meio de interação social, produzida por especialistas (produtores) para outras pessoas (receptores); o fazer musical é um comportamento aprendido, através do qual sons são organizados, possibilitando uma forma simbólica de comunicação na interrelação entre indivíduo e grupo" (PINTO, 2001: 224).

Essa relação torna-se evidente quando falamos em ouvir e entender música, ou seja, em percepção musical. Entende-se como percepção o processo pelo qual o ser humano organiza e vivencia informações, basicamente de origem sensória. Longe de existir um consenso, música e sua percepção cognitiva são assuntos que já causaram polêmica entre representantes de diversas disciplinas. Assim, há psicólogos que acreditam em processos cognitivos como universais de natureza, pois cada ser humano dispõe de um sistema nervoso. A visão oposta que essa pesquisa procurará seguir, já enxerga na diversidade cultural a predisposição para uma preferência e seleção naturais dos padrões visuais e auditivos, fazendo de cada processo cognitivo um caso específico e culturalmente impregnado (PINTO, 2001: 236-237).

Todas essas questões sobre a essência da linguagem musical são respondidas a partir das especificidades culturais de cada povo, grupo social e indivíduos. De acordo com essa visão, é como arte e conhecimento sociocultural que a música deve ser entendida. Essa é a pretensão de desenvolvimento deste trabalho de pesquisa. 
Qualquer que seja nosso comportamento diante da música, de alguma maneira nos apropriamos dela e criamos algum tipo de representação sobre ela. Sabemos da alegria que os jovens encontram em se comunicar com outros jovens e demais pessoas, graças às suas músicas, executadas ou simplesmente ouvidas, pois vivem, acolhem e levam em conta a diversidade cultural, o que lhes parece, com frequência, ser o valor essencial na escuta e na atividade musicais. Com isso, conseguem dividir e se respeitar, pois cada um pode ter a sua parte de colaboração na música, como executor ou audiência, fazendo parte de um movimento cultural e criando uma identidade para o grupo.

Outro aspecto fundamental na relação entre História, música e o processo de aprendizagem é a articulação entre texto e contexto para que a análise histórica não seja reduzida e se limite à própria importância da música, deixando em segundo plano a sua contextualização. O grande desafio do pesquisador é mapear os sentidos embutidos numa obra musical, bem como suas formas de inserção na sociedade e na história.

O problema da recepção cultural tem sido um dos grandes desafios dos estudos culturais, e se torna ainda mais difícil no caso da história cultural da música, na medida em que o objeto se encontra distante no tempo, construído a partir de uma diacronia que implica na impossibilidade de reconstruir ou mapear a experiência cultural dos agentes que tomaram parte no processo estudado. Como mapear e compreender os "usos e apropriações" (CERTEAU, 1994: 40) que professores e alunos fazem da música é um dos principais desafios desta pesquisa.

Professores e alunos, mesmo sem conhecimento técnico, possuem dispositivos emocionais para dialogar com a música. Tais dispositivos, verdadeiras competências de caráter espontâneo ou científico, não são apenas resultado da subjetividade do ouvinte diante da experiência musical, mas também sofrem a influência de ambientes socioculturais, valores e expectativas político-ideológicas, situações específicas de audição, repertórios culturais socialmente dados. No diálogo - decodificação - a apropriação dos ouvintes não se dá só pela letra ou só pela música, mas pelo encontro, tenso e harmônico a um só tempo, dos dois parâmetros básicos e de todos os outros elementos que influenciam produção e a apropriação da canção (vestimentas, comportamento e dança). Tudo isso gera o que pretendo definir como consciência musical.

A visão clássica que separa músicos e ouvintes em dois blocos estanques e delimitados deve ser revista. Um compositor ou músico profissional, por um lado, é, em certa medida, um ouvinte, e sua escuta é fundamental para a própria criação musical. Por outro lado, os ouvintes não constituem um bloco coeso, uma massa de manipulados pela indústria cultural e nem um 
agrupamento caótico de indivíduos irredutíveis em seu gosto e sensibilidade. O ouvinte opera num espaço de relativa liberdade, influenciado por estruturas objetivas (comerciais, culturais e ideológicas) que lhe organizam um campo de escutas e experiências musicais (NAPOLITANO, 2002: 82).

$\mathrm{Na}$ verdade, agentes e instituições formadoras do gosto e das possibilidades de criação e consumo musicais formam um contexto imediato, cujo pesquisador deve articular ao contexto histórico mais amplo do período estudado com as músicas apresentadas aos alunos. Trata-se de uma maneira de problematizar a "escuta" musical do aluno em relação ao processo de construção do conhecimento histórico.

“Os sentidos enigmáticos e polissêmicos dos signos musicais favorecem os mais diversos tipos de escuta ou interpretações -verbalizadas ou não- de um público ou de intelectuais envolvidos pelos valores culturais e mentais, altamente matizados e aceitos por uma comunidade ou sociedade. A partir dessas concepções, a execução de uma mesma peça musical pode provocar múltiplas 'escuta' (conflitantes, ou não) nos decodificadores de sua mensagem, pertencentes às mais diversas sociedades, de acordo com uma perspectiva sincrônica ou diacrônica do tempo histórico” (CONTIER, 1991: 151).

Todas essas questões de ordem histórica, sociológica e antropológica não negam o nível da experiência estética subjetiva da música. Colocam uma outra ordem de reflexões ligadas às questões cognitivas do processo de construção do conhecimento histórico em sala de aula.

Levando em conta a História Cultural, a relação entre conhecimento histórico e a música se resolve no plano epistemológico, mediante aproximações e distanciamentos, entendendo-as como diferentes formas de expressar o mundo, que guardam distintas aproximações com o real. Ambas são formas de explicar o presente, inventar o passado, imaginar o futuro. Valem-se de estratégias retóricas, estetizando em narrativa os fatos dos quais se propõem falar. Também são formas de representar inquietudes e questões que mobilizam os homens em cada época de sua história, e, nessa medida, possuem um público destinatário (leitor e ouvinte), atuando como aproximações que unem o conhecimento histórico e a música.

Nesse sentido, é salutar a utilização da linguagem musical no ensino de história com o objetivo de fazer com que os alunos compreendam os motivos pelos quais as pessoas atuaram no passado de uma determinada forma, e o que pensavam sobre a maneira como o fizeram. 
Uma das principais preocupações dessa pesquisa é verificar como o professor e seus alunos utilizam modelos de explicação histórica e, ao mesmo tempo, averiguar se, no emprego de um desses tipos de noções, há possibilidade de extrair quais sentidos e influências estão por trás dessas explicações estimuladas pela linguagem musical e as representações sociais estabelecidas pelas mesmas.

\section{A pesquisa etnográfica e as questões relativas à aproximação do objeto}

Inicialmente o instrumento de pesquisa incluiu uma série de questões que buscam delinear o perfil socioeconômico de cada estudante e da professora Marli. Foram observados em sala de aula, servindo de balizamento para as análises posteriores da turma e principalmente em relação à escolha dos alunos a serem entrevistados.

Após a aplicação desse questionário (anexos I e II) e o período de observação das aulas da turma, os estudantes e o professor foram entrevistados, adotando-se algumas práticas da chamada microetnografia ou microanálise com gravações sonoras digitais como fonte primária. Distinguindo-se da etnografia em geral, o foco principal não foi mais o que estava acontecendo naquele momento, mas como aconteceu. O texto-base não foi apenas a narração, mas também a análise das reações dos entrevistados e a transcrição de partes das entrevistas consideradas essenciais para a pesquisa. A possibilidade de escutar várias vezes as gravações, discutir e confrontar diferentes interpretações tornou a análise cada vez mais refinada, até atingir uma aproximação mais precisa ao objeto pesquisado com as respectivas representações.

A pesquisa etnográfica, de maneira abrangente, é a tentativa de descrição da cultura como um sistema de símbolos construídos². O etnógrafo encontra-se, assim, diante de diferentes formas de interpretação da vida, formas de compreensão do senso comum, com significados variados atribuídos pelos participantes às suas experiências e vivências, tentando mostrar esses significados múltiplos ao leitor. Portanto, os métodos etnográficos podem permitir uma aproximação gradativa ao significado ou à compreensão dos participantes, isto é, de uma posição de estranho o pesquisador vai chegando cada vez mais perto das formas de compreensão do grupo estudado, partilhando e refletindo com eles os significados atribuídos ao objeto de pesquisa.

\footnotetext{
2 "O conceito de cultura (...) é essencialmente semiótico. Acreditando como Max Weber, que o homem é um animal amarrado a teias de significados que ele mesmo teceu, assumo a cultura como sendo essas teias e a sua análise; portanto, não com uma ciência experimental em busca de leis, mas como uma ciência interpretativa, à procura de significados" (GEERTZ, 1989: 15).
} 
A etnografia, no entender de GEERTZ (1989), seria uma "descrição densa", em que o pesquisador enfrenta de fato uma multiplicidade de estruturas conceituais complexas, muitas delas sobrepostas ou amarradas umas às outras, que são simultaneamente estranhas, irregulares e inexplícitas, e que ele tem que, de alguma maneira, primeiro apreender e depois apresentar. Fazer uma pesquisa etnográfica é como tentar ler (no sentido de construir uma leitura de um objeto) um manuscrito estranho, desbotado, cheio de elipses, metáforas, incoerências, emendas suspeitas e comentários tendenciosos, escrito não com os sinais convencionais da fala e da escrita, mas com exemplos transitórios de comportamento modelado (GEERTZ, 1989: 20).

O tipo de pesquisa de inspiração etnográfica pelo qual optei contribui para a compreensão dos fenômenos históricos e educacionais, ao menos dentro das sociedades escolarizadas, e fundamenta suas raízes teóricas na sociolingüística americana. Tem-se a tendência de denominá-la "microetnografia", pelo fato de concentrar-se na análise detalhada do registro (gravador ou vídeo) da interação que se dá nos "eventos educacionais" de qualquer tipo (EZPELETA \& ROCKWELL, 1986: 41). A contribuição desta pesquisa no campo educacional, com aspectos etnográficos, coloca em destaque aspectos da cultura escolar, como as categorizações que professores e alunos fazem do conhecimento histórico tornando-o um conhecimento escolar que interfere na consciência histórica e nas representações sociais de ambos.

As duas fases da pesquisa que estão relacionadas às atividades de campo acabaram suscitando algumas questões relativas à aproximação do objeto que, neste caso, é composto pela professora, pelos alunos e pela própria cultura escolar ${ }^{3}$ que envolve esses agentes no processo de aprendizagem. Daí a importância da realização de uma descrição metódica e minuciosa dos processos de interação social no interior dos estabelecimentos escolares e das salas de aula apreendidos como microssociedades que possuem uma cultura singular (FORQUIN, 1992: 28).

Ao analisarmos um determinado objeto no interior da cultura escolar, identificamos a formação de um novo conhecimento (como um modo de saber e não mera apropriação), fazendo com que a teoria acompanhada de certos métodos e técnicas estabeleça uma relação constitutiva da prática. Nesse caso, a pesquisa é dirigida para entender a razão do objeto, no caso alunos e professora, da forma como ele se apresenta, e não para comprovar a validade da

\footnotetext{
3 “'(...) a cultura escolar dota assim os indivíduos de um corpo comum de categorias de pensamento e cumpre por isso uma função de integração lógica ao mesmo tempo que de integração moral e social; estando os espíritos assim modelados predispostos a entreter com seus pares uma relação de cumplicidade e de comunicação imediatas" (FORQUIN, 1992: 36).
} 
teoria, ou de uma hipótese prévia. A mediação fundamental da teoria e da prática, uma se constituindo dentro da outra, vem a ser a reflexão constante, principalmente em uma pesquisa de campo, inclusive com a alteração de eventuais interpretações no curso da investigação (MARSON, 1984: 48-49).

Trata-se, nesse caso, de uma reflexão sobre o significado do objeto de pesquisa (professor e aluno) como sujeito: por quem fala tal objeto? De que história particular participou? Que ação e que pensamento estão contidos em seu significado? O que o fez perdurar como depósito da memória? Em que consiste seu ato de poder? Esse objeto não é apenas espelho da realidade, mas essencialmente representação do real, de momentos particulares da realidade; sua existência é dada no âmbito de uma prática determinada, transformando-se em um código de relação social que age no presente; e, em sendo representação, é a fala da prática e a visão de parte o real (MARSON, op. cit.: 53).

Se essa análise for exercida criticamente, e se o pesquisador dispuser de amplos recursos teóricos e informativos, a análise do objeto composto por agentes do processo pedagógico (professora e alunos) é capaz de revelar uma historicidade contraposta às versões dadas pelos argumentos da memória instituída através instituições educacionais, recuperando assim a presença dos sujeitos envolvidos no processo de construção do conhecimento histórico na prática pedagógica.

No que diz respeito à metodologia e aos conceitos aplicados nesta pesquisa de campo, procurei seguir as seguintes perspectivas:

1) que professores e alunos sejam considerados como sujeitos de um conhecimento a ser pesquisado;

2) que, na elaboração de novas formas de pesquisa, principalmente através da etnografia, se considerem professores e alunos não apenas objetos de pesquisa, mas colaboradores que facilitam uma aproximação e uma menor estranheza entre pesquisador e pesquisados;

3) que seja uma pesquisa não sobre, mas para o ensino e os professores de História, e que futuramente seja apropriada pelos mesmos;

4) e que, no campo da prática escolar, encontremos os elementos fundamentais que intervêm na seleção e na recontextualização dos currículos por parte de professores e alunos.

Em resumo, esta pesquisa de campo de inspiração etnográfica tem como principal referência a escolarização, mediada pela linguagem musical e através do ensino de História, levando em consideração o cotidiano escolar, o saber e as representações históricas dos seus principais personagens: professores e alunos. 


\section{A importância do saber do professor e as representações dos alunos}

A professora Marli, como sujeito desta pesquisa, tem sua existência como agente histórico-social firmado no âmbito de uma prática determinada condicionada pela trajetória de vida pessoal e profissional. Isso acaba produzindo um saber que lhe sustenta a representação histórica e a utilização da linguagem musical como mediação pedagógica em relação aos alunos.

Ao longo da observação e também através das repostas obtidas durante a entrevista, foi possível notar que a prática pedagógica com a utilização da linguagem musical encontrase ligada a um saber-fazer da professora construído ao longo da sua trajetória de vida social e profissional. A análise da prática e do discurso da professora evidencia, no percurso profissional, as expectativas pessoais e familiares que se cruzam com as oportunidades e os constrangimentos institucionais e sociais ao longo da sua carreira profissional.

No ambiente escolar, a ação profissional da professora é estruturada por duas séries de condicionantes: os ligados à transmissão da matéria (condicionantes de tempo, de organização sequencial dos conteúdos, das mediações utilizadas - como no caso da música -, de alcance de finalidades, de aprendizagem por parte dos alunos, de avaliação, etc.) e os condicionantes ligados à gestão das interações com os alunos (manutenção da disciplina, gestão das ações desencadeadas pelos alunos, motivação da turma, etc.).

O trabalho docente no ambiente escolar consiste em fazer essas duas séries de condicionantes convergirem, em fazê-las colaborar entre si. Nesse sentido, a transmissão da matéria e a gestão das interações não só constituem elementos do trabalho docente, mas o próprio cerne da profissão. É por isso que o estudo dos conteúdos transmitidos, a maneira como o professor os compreende, os organiza, os apresenta, utilizando-os para interagir com os alunos faz parte integrante de qualquer pesquisa sobre a sala de aula (TARDIF, 2006: 219220).

Outro ponto importante a ser destacado é o modo como os alunos interagem com os saberes disciplinares e curriculares por intermédio da ação do professor, constituindo um objeto essencial para esse tipo de pesquisa de campo, principalmente se levarmos em conta as representações históricas que os alunos possuem em relação a esses conteúdos. As representações históricas de professores e alunos, construídas pela audição de composições 
musicais, são eficazes auxiliares na construção do conhecimento histórico. Propiciam a identificação de diferentes significados dos elementos definitivos e provisórios contidos nas representações históricas ${ }^{4}$, que podem se transformar em uma ponte entre o presente e o passado histórico.

As transformações históricas ocorrem em diferentes momentos do social e o processo educativo não seria excluído e nem independente de todas essas mudanças. Elas envolvem um conjunto de relações existentes entre os significantes (imagens, palavras e sons) e os seus significados (as representações). Tratando-se das análises das representações construídas para atender às exigências educacionais, esta pesquisa procura refletir basicamente sobre duas situações: uma delas ligada à apreensão e construção do conhecimento em sala de aula, isto é, a relação de aprendizagem existente entre os professores e os alunos; e a outra, às múltiplas mercadorias produzidas pela indústria cultural, como as músicas utilizadas como material didático em sala de aula.

Se esta pesquisa tem como principal objetivo entender a importância da música para a construção do conhecimento histórico em sala de aula, obrigatoriamente tenho um propósito. Levo em conta que todas as práticas históricas dependem das representações utilizadas pelos alunos e a professora para darem sentido a sua realidade, contribuindo assim para a construção de uma "visão de mundo".

O conceito de representação social, na verdade, retoma o conceito de "representação coletiva" de autores clássicos como Mauss e Durkheim, pois a noção de "representação coletiva" deles possibilita a articulação das três modalidades de relação com o mundo social: de início, o trabalho de classificação e de recorte que produz configurações intelectuais múltiplas pelas quais a realidade é contrariamente construída pelos diferentes grupos que compõem uma sociedade; em seguida, as práticas que visam a fazer reconhecer uma identidade social, a exibir uma maneira própria de ser no mundo, a significar simbolicamente um estatuto e uma posição; enfim, as formas institucionalizadas e objetivas em virtude de quais "representantes" (instâncias coletivas ou indivíduos singulares) marcam, de modo

\footnotetext{
${ }^{4}$ As mudanças, no presente, experimentadas como carentes de interpretação, são interpretadas em articulação com os processos temporais rememorados do passado; a narrativa histórica torna presente o passado, de forma que o presente aparece como sua continuação no futuro. Com isso a expectativa do futuro vincula-se diretamente à experiência do passado: a narrativa histórica rememora o passado sempre com respeito à experiência do tempo presente e, por essa relação com o presente, articula-se diretamente com as expectativas de futuro que se formulam a partir das intenções e das diretrizes do agir humano dos estudantes e professores entrevistados. Essa íntima interdependência de passado, presente e futuro é conhecida como uma representação histórica e serve à orientação da vida humana prática atual desses sujeitos (RÜSEN, 2001: 64).
} 
visível e perpétuo, a existência do grupo, da comunidade ou da classe (CHARTIER, 1991: $183)$.

Dessa maneira, uma dupla via de análise se abre. Nesse caso, uma deve pensar a construção das identidades sociais como resultado de relação de força entre as representações impostas pelos que detêm o poder de classificar, nomear e de definição de aceitação ou resistência que cada grupo social produz de si mesmo, como os estudantes e professores. Outra perspectiva é a que considera o recorte social objetivado como a tradução do crédito conferido à representação dá de si mesmo. Logo, surge a capacidade de fazer reconhecer a existência a partir de uma demonstração de unidade, que, no caso desta pesquisa, é representada por estudantes e professores de uma determinada escola.

\section{Etapas da pesquisa}

Inicialmente, a pesquisa se apoiou em leitura, resenhas e levantamento de categorias de análise em dois grupos de textos: 1) estudos sobre a música no processo de aprendizagem e sua relação com a História; 2) textos sobre as representações e a construção do conhecimento histórico de professores e alunos em sala de aula.

A segunda fase esteve vinculada à pesquisa de campo: observações das aulas de uma turma de $5^{\text {a }}$ série da escola pública da rede municipal de São Paulo (setembro a dezembro de 2007). Nesse local, a professora mantinha um projeto que envolvia a linguagem musical nas aulas de História.

Já a terceira fase foi composta por oito entrevistas com os alunos (junho de 2008) e com a professora (maio de 2009) que compõem uma amostragem qualitativa dos estudantes observados e da professora construindo a leitura de um objeto que valoriza o discurso e a experiência pessoal do entrevistado durante as aulas que foram observadas. As entrevistas com alunos foram selecionadas de acordo com os seguintes critérios: gênero (masculino ou feminino), faixa etária, processo ensino-aprendizagem (maior e menor rendimento, indiferença e comprometimento em relação ao curso em sala de aula), num trabalho de inspiração etnográfica. O roteiro das entrevistas (anexo IV) com os alunos foi elaborado a partir das observações das aulas e da utilização de pequenos textos didáticos (anexo IV) que serviram de estímulo para que os entrevistados estabelecessem relações entre as aulas e as músicas trabalhadas em sala de aula com a professora. Com isso, tentei estabelecer uma diversidade qualitativa dos sujeitos que formaram uma amostra qualitativa do universo do estudante e do professor, facilitando, assim, as associações e relações que propiciam uma 
análise da representação histórica desse aluno em relação aos conteúdos desenvolvidos em sala de aula.

A última fase foi composta pela análise dos dados coletados durante o período de observação e entrevistas. Isso para que, posteriormente, fosse possível utilizar esses dados nas respostas às questões colocadas anteriormente, resultado desse percurso de observações, análises e reflexões.

O trabalho desenvolvido, na segunda fase da pesquisa, foi o resultado de onze visitas semanais, entre setembro e dezembro de 2007, a uma escola de Ensino Fundamental da rede municipal de ensino de São Paulo localizada no Pacaembu, bairro residencial de classe média alta, situado na zona oeste da cidade. O perfil sócio-econômico dos alunos que frequentam essa escola não corresponde ao padrão social do bairro, pois são de classe média baixa ou pobres, sendo que a maioria nesta unidade escolar não morava na região e sim em bairros periféricos de São Paulo e Grande São Paulo, porque a escola se encontra próxima do local de trabalho dos pais. Uma boa parte dos alunos que não residem na região, enquanto não estão na escola, permanecem nos Centros de Juventude (CJs) das paróquias das imediações. Já aqueles que moram próximos à escola são filhos de funcionários das casas e condomínios de luxo do bairro.

De proporção média, a escola tem aproximadamente 800 alunos e funciona em três períodos (distribuídos entre 7h:00 h e 23h:05). Possui onze salas de aula (distribuídas em dois andares), além de salas de leitura, de informática (com aproximadamente vinte computadores) e de vídeo, um pequeno pátio e cozinha proporcional. Todos os corredores e salas possuem grades. Completam esse cenário, duas quadras poliesportivas cercadas por alambrados e uma pequena área de estacionamento. Destaca-se também a organização das salas de informática e de leitura, amplas e com boa quantidade de computadores e livros, aos quais todos os alunos tinham acesso.

O coordenador Cláudio tem grande experiência como professor de ensino fundamental ciclo I ( $1^{\mathrm{a}}$ à $4^{\mathrm{a}}$ série $)$ e, há dois, ascendeu ao novo cargo após terminar o mestrado em pedagogia na Faculdade de Educação da Universidade de São Paulo. Receptivo, apresentou-se e conduziu-me até a sua sala para registrar os meus dados pessoais e os objetivos da minha pesquisa no livro de estágio da escola, chamando a minha atenção o grande número de registros. Esse tipo de atitude foi confirmado pela professora que acompanhei durante a pesquisa: ressaltou o fato de a escola aceitar com naturalidade a presença de estagiários, exigindo apenas como regra no máximo dois estagiários por aula, para não comprometer o trabalho do professor com os alunos. 
Considerada modelo de ensino para a Coordenadoria de Educação Pirituba, essa escola sempre fez parte de projetos pioneiros da Secretaria Municipal de Educação em parceria com a PUC e a USP. Além disso, é muito procurada por estagiários e pesquisadores devido à localização central.

A escola foi selecionada como campo de pesquisa devido à presença da professora Marli que privilegia o uso da música nas aulas de História. O trabalho da professora é singular, pois a maioria dos professores utiliza essa estratégia de forma pontual, o que, como descreverei, não ocorre com a professora Marli. Fiquei sabendo da sua prática pedagógica através de um folder com a programação dos cursos de especialização do Sindicato dos Professores de São Paulo (Sinpro- SP), onde ela ministraria um curso no segundo semestre de 2007 com o título "Cantando a história com respeito às diferenças". Telefonei para o sindicato, do qual sou filiado, deixando o meu telefone e e-mail para que a professora entrasse em contato, algo que aconteceu dois dias depois. Pelo telefone trocamos algumas informações, e a professora demonstrou grande interesse na pesquisa e no meu trabalho em sala de aula. Assim acordamos um horário de trabalho (quartas - feiras entre às 15:00 e 16:30), quando eu poderia observar o intervalo e a sua quarta aula na $5^{a}$ série $B$, que tinha em sua carga horária semanal três aulas de História.

A partir das descrições e observações feitas ao longo desse exercício etnográfico, acredito que três pontos deveriam merecer análise e reflexões aprofundadas: como a escola se configura em um campo político e legitimador de práticas pedagógicas; como essas práticas pedagógicas, no caso, baseadas na linguagem musical se encontram inseridas na cultura escolar; e finalmente como essa linguagem musical se relaciona a prática do ensino de história em sala de aula, procurando entender de que forma a linguagem musical contribui na construção do conhecimento histórico.

A terceira fase da pesquisa foi composta por oito entrevistas com os alunos (junho de 2008) e uma entrevista com a professora Marli (maio de 2009). A amostragem qualitativa dos estudantes observados construiu uma leitura de um objeto que valorizou o discurso e a experiência pessoal do entrevistado durante as aulas que foram observadas durante o segundo semestre de 2007. Para que isso ocorresse efetivamente, foi estabelecido um roteiro (anexo IV) baseado em quatro pequenos textos relacionados aos temas históricos desenvolvidos pela professora através da linguagem musical (anexo IV).

Os oito estudantes entrevistados foram selecionados de acordo com os seguintes critérios: gênero, como foi citado anteriormente, adotando-se algumas práticas da chamada microetnografia ou microanálise com gravações sonoras digitais como fonte primária. 
Distinguindo-se da etnografia em geral, o foco principal não é mais o que está acontecendo naquele momento, mas como está acontecendo. O texto-base não será apenas a narração, mas também a análise das reações dos entrevistados e a transcrição de partes das entrevistas consideradas essenciais para a pesquisa. A possibilidade de escutar várias vezes as gravações, discutir e confrontar diferentes interpretações tornou a análise cada vez mais refinada, até atingir uma aproximação mais precisa ao objeto pesquisado com suas representações.

Nesse caso, as representações sociais determinam tanto o caráter do estímulo, como a resposta que ele incita. Conhecê-las e explicar o que elas são e o que elas significam são o primeiro passo em toda análise de uma situação ou de uma relação social que envolve um objeto, constituindo-se assim um meio de predizer a evolução das interações grupais, que nesse caso envolve professores e alunos. (MOSCOVICI, 2003: 100).

Os resultados dessas entrevistas gravadas digitalmente estabeleceram um perfil qualitativo dos discentes em relação às aulas de história e à utilização das músicas, levando em consideração os seguintes aspectos: identificação dos temas através dos textos; a relação entre os textos e as músicas ouvidas em sala de aula; a relação entre os textos e outras músicas sugeridas pelos alunos; e a relação entre os textos, as músicas e outras linguagens trabalhadas em sala de aula. Também faz parte desse perfil qualitativo canções, para que possamos analisar a importância da utilização da linguagem musical em uma tabulação das representações dos alunos entrevistados em relação aos textos e às sala de aula na construção do conhecimento histórico (anexo V).

Quanto à entrevista da professora (maio de 2009), foi feita praticamente dois anos depois da pesquisa de campo e um ano após as entrevistas com os alunos. Isso fez com que os resultados obtidos anteriormente em relação aos questionários, aplicados em novembro de 2007 (anexo III) e às entrevistas com os alunos, ocorridas em junho de 2008 (anexo V), interferissem na elaboração do roteiro final da entrevista da docente (anexo VI). Como no caso dos alunos, adotaram-se as mesmas práticas da microetnografia ou microanálise com gravação sonora digital como fonte primária para a elaboração de um perfil qualitativo da professora, levando em consideração os seguintes pontos em relação à trajetória de vida da profissional: a influência musical na infância, na adolescência, na escola, na época de faculdade e no início da carreira do magistério, procurando evidenciar as referências musicais definitivas e provisórias da docente em relação à linguagem musical, que podem fazer parte da consciência musical e histórica da professora.

Esse perfil qualitativo é complementado por uma tabulação das falas da professora em relação às canções, para que possamos analisar a importância da linguagem musical dentro e 
fora da sala de aula na construção do conhecimento histórico no ponto de vista do docente, levando em consideração os seguintes aspectos: a construção da aula utilizando a linguagem musical; a relação entre música e conteúdo; outras músicas que poderiam ser utilizadas na $5^{\text {a }}$ série; o "aprender" História através da linguagem musical; a utilização esporádica da música na sala de aula pelos professores; a relação entre a música e as demais linguagens na sala de aula; a música e a cultura escolar e os resultados profissionais da professora com a sua prática pedagógica. (anexo VII).

Alguns pontos importantes que foram discutidos ao longo dos capítulos. Com o fim das entrevistas, o processo de análise e reflexão sobre as observações e os dados obtidos durante as fases anteriores já descritas, levou em consideração alguns pontos relevantes para esta pesquisa.

\section{Música e cultura escolar}

O primeiro ponto importante desenvolvido ao longo do primeiro capítulo é estabelecer alguns pontos de reflexão sobre a relação entre música e cultura escolar a partir das observações ligadas às atividades de campo envolvendo seus agentes no processo de aprendizagem, mediado pela linguagem musical. A relação entre música e cultura escolar será discutida através de três aspectos: as músicas veiculadas durante a hora do intervalo; a música e a inexpressão corporal da chamada "aula pública"; e como esse projeto pedagógico coletivo não faz parte da cultura escolar da comunidade. Essas reflexões procuram responder à seguinte questão: como as práticas pedagógicas mediadas pela música interferem e transformam a cultura escolar?

A prática e o discurso dos alunos e da professora revelam que, na comunicação cotidiana contemporânea, com meios de comunicação cada vez mais individualizados, nós e nossos alunos estamos correndo o risco de ficarmos mais fechados em nós mesmos, e a escola acaba reafirmando essa maneira de ser. A música inserida isoladamente sem um projeto pedagógico efetivo, apenas legitima ainda mais esse aspecto individualista da cultura escolar contemporânea, mesmo nos seus momentos coletivos de alegria, como nas festas, shows, festivais, ou qualquer outro tipo de evento na escola que envolva música.

Mesmo estabelecendo uma prática musical, dentro e fora da sala de aula, a escola continuou funcionando como repressora e disciplinadora dos corpos dos sujeitos, algo evidenciado pela inexpressão corporal dos alunos e a preservação da cultura do silêncio. 


\section{Gosto musical, representação, memória e consciência}

Se as práticas pedagógicas mediadas pela música interferem na cultura escolar, ela também é influenciada pelos gostos musicais dos alunos e da professora, algo que discuto ao longo do capítulo segundo. O gosto musical, no contexto familiar se dá essencialmente de forma afetiva, pois, nessa esfera, o processo de mediação cultural dos jovens encontra e participa de relações, cuja ligação afetiva (sentimentos e emoções) interligava-se também com a dimensão sonoro-musical.

O gosto musical se afirma, principalmente, nas esferas do cotidiano familiar e do lazer e da escola, onde ouvir música, principalmente em relação às duas primeiras esferas, é ouvir emotivamente, pois a música é utilizada para que a mesma desperte ou reforce algo já latente em nós mesmos em busca de uma identidade com o outro. $\mathrm{Na}$ escola, pelo contrário, a audição musical é apresentada, na maioria das vezes, como uma atividade formal com frequência, duração, objetivos e conteúdos pré-determinados. Mas quando o gosto musical, mesmo na escola, transforma-se em uma representação afetiva da mediação elaborada pelo aluno em relação ao mundo que o cerca, e que, devido ao seu caráter eminentemente afetivo transforma-se em memória pessoal e modelo de referência para a apreensão e assimilação das novas audições dos jovens, similares ou não as anteriores, revela o que podemos chamar de consciência musical.

Na pirâmide hierárquica estabelecida por SCHOPENHAUER (1974), a música encontra-se acima das demais artes. A música não expõe apenas uma ideia ou leva à abstração de algumas imagens, que identifiquei adiante de "paisagens sonoras". A música é muito especial, pois é a linguagem em si mesma. A arte dos sons não reproduz uma intuição estética; ela é a mensagem direta e imediata do âmago das coisas. Para o autor de "O mundo como vontade e representação", as representações estimuladas pela linguagem musical são construídas através de uma memória que se utiliza essencialmente do tempo e é revelada, em grande parte, pelo gosto musical de cada um de nós. Portanto, como seria essa memória musical?

Basicamente seria composta por dois elementos interdependentes: a identificação e a afetividade. A memória de identificação seria a capacidade que temos, na maioria dos casos, de identificar músicas que ouvimos antes, processo semelhante à memória que temos de rostos, fotografias, sabores e cheiros, com certo grau de variação individual, mas todas, ao 
escutarem uma canção, estabelecem padrões de identificação a partir de experiências anteriores que são balizadas pela afetividade que, por sua vez, faz parte da memória do sujeito.

A memória musical existe e, como os outros tipos de memória, encontra-se enraizadas em diferentes contextos. A rememoração pessoal de uma música estabelece uma sincronia com a existência social atual de cada pessoa emergindo aquela forma que chamamos de lembrança. Para HALBWACHS (1995), a lembrança é a intersecção de muitas correntes do "pensamento coletivo". Algo que se torna mais fácil se tais fatos estiverem ligados a uma determinada música que nos faz relembrar o contexto e as emoções do passado. A construção dessas imagens, quando estimuladas pela afetividade da linguagem da música, forma uma memória que se transforma em consciência musical.

Por meio de imagens, sentimentos e pensamentos resultantes dos diversos ambientes sociais marcantes em nossa vida, significativamente por determinada trilha sonora que compõe história de cada um, essa consciência musical e individual vai balizar o nosso gosto e a nossa audição até o final de nossas vidas. Assim a consciência musical tem uma função prática que confere à realidade direção temporal, orientação que pode guiar intencionalmente a ação através da mediação da linguagem musical, auxiliando na construção da memória histórica e, consequentemente, na formação da consciência histórica dos alunos e da professora.

\section{As relações da música com a linguagem pictórica e escrita}

A música como fenômeno de mediação cultural estabelece uma pluralidade de memórias e projetos culturais individuais ou coletivos. Qualquer que seja o comportamento dos alunos e da professora diante da música, de alguma maneira se apropriam da canção por meio de um processo de percepção estética de apreciação musical.

Essa apropriação acaba gerando representações históricas dos alunos e da professora estimuladas pela linguagem musical, reveladoras de determinados aspectos da música como fenômeno de mediação cultural, como as relações das canções com a linguagem pictórica e escrita. Esse aspecto será discutido ao longo do capítulo terceiro. Importante também é o ouvir emotivo dos alunos afim de que desperte ou reforce algo já neles latente, provocando uma empatia entre a professora e os estudantes. Mas questiona-se até que ponto essa afetividade proporcionada pela música se transforma em empatia histórica. Trata-se de uma questão que só pode ser respondida com uma análise mais aprofundada das representações contidas nas oito entrevistas com os alunos. 
Nos momentos de audição coletiva que não foram direcionadas pela professora, observei que a música foi também utilizada como fundo acústico, procurando criar atmosferas ou ambientes sonoros, inclusive no preenchimento de espaços deixados pela ausência de conversação ou interação entre os alunos no decorrer da aula. A formação desse fundo sonoro pode ser caracterizada como "paisagem sonora", conceito inicialmente construído pelo musicólogo canadense Murraya Schafer, que vai facilitar, por exemplo, a relação entre a linguagem musical e pictórica (PINTO, 2001:248).

Os desenhos como atividade complementar à linguagem musical foram encarados com naturalidade pelos alunos, pois a música acabou formando várias "paisagens sonoras" que expressas a partir da linguagem pictórica, além de serem exemplos de representação que relacionam a letra do livro didático à canção ouvida em sala de aula. Utilizo o termo imagem sonora como toda informação sonoro-ambiental que compõe a paisagem musical e toda informação sonora acrescida ao ambiente torna-se, naquele momento, parte integrante da paisagem sonora; descrevê-las é como olhar a nossa volta e traduzir os sons que ouvimos através de uma representação gráfica. Algo que aparece destacado durante as entrevistas.

Apesar da importância da linguagem pictórica relacionada à música, o que mais chamou a atenção é que a maioria das atividades pedagógicas descritas privilegiava a linguagem escrita. A utilização do texto legitimou, de certa forma, a prática pedagógica com a linguagem musical, pois o texto permite levar mais longe o deslocamento da veracidade à verossimilhança, pondo em discussão os efeitos de real e de verdade que uma narrativa histórica pode produzir, tomando o lugar do que teria acontecido um dia. Ao trabalhar com a linguagem musical como documento, a professora se deparou, forçosamente, com a necessidade de pensar o estatuto do texto da letra da canção, do livro didático e da avaliação escrita dos alunos.

Além da empatia, do conceito de "paisagem musical" e a relação da música com o desenho e o texto, outra questão que abordei no capítulo terceiro foi a escolha do repertório, que não está apenas relacionada ao gosto e a trajetória de vida e profissional da professora, sobre o que falarei mais adiante, mas também a uma certa tradição cultural da MPB (Música Popular Brasileira), consolidada nos anos 80 e 90, e que ainda se mantém nos dias de hoje.

A análise da linguagem musical em sala de aula também se tornou um caminho para refletir como os alunos interagem com os saberes disciplinares e curriculares por intermédio da ação do professor. Essa interação se constitui em objeto essencial para este tipo de pesquisa de campo, principalmente se levarmos em conta as representações históricas que os alunos possuem em relação a tais conteúdos. 
As oito entrevistas com os alunos, analisadas ao longo do capítulo quarto, estabeleceram um importante cruzamento entre a linguagem escrita e a musical para o entendimento e a fixação do tema. Não cabe aqui discutirmos se essas representações apresentadas pelos alunos são válidas ou não, do ponto de vista da ciência histórica. Não se deve negar, porém, a importância da relação do texto escrito com a linguagem musical na formação da chamada consciência histórica, pois os alunos conseguiram estabelecer uma relação com um passado recente - composto pelas aulas da professora Marli, o texto do livro didático, a canção na sala de aula, os desenhos, as gravuras e as cenas de uma minissérie com um presente, que naquele momento da entrevista, um ano mais tarde, foi representado pelo texto-estímulo apresentado pelo entrevistador e as aulas de História na $6^{\mathrm{a}}$ série, com outros conteúdos, sem música na sala de aula e com outra professora.

Os alunos, durante as entrevistas, construíram representações que evidenciavam a forma linguística dentro da qual a consciência histórica realizou a sua função orientadora, que é a narrativa. Nesse caso, constitui a narrativa, especificamente, a consciência histórica, na medida em que recorre às lembranças para interpretar as experiências do tempo. A lembrança é, para a constituição da consciência histórica, por conseguinte, a relação determinante com a experiência do tempo. Algo que fica destacado quando o tema histórico se torna objeto de comparação ao longo do tempo, seja por meio da fala da professora, ou da lembrança da canção executada.

\section{A prática docente e o saber-fazer da música em sala de aula relacionados à vida social e profissional da professora}

Já as observações e as narrativas em relação à professora, desenvolvidas ao longo do capítulo quinto, revelam forte necessidade natural da docente de legitimar externa e internamente à comunidade escolar a sua prática pedagógica e o seu trabalho com a linguagem musical. Com isso visava à busca não só do ganho de capital cultural como do fortalecimento político no campo da escola, pois lá se encontrava há apenas dois anos, como também pretendia entrar na esfera acadêmica, já que, a partir da sua prática docente, pretendia desenvolver um projeto de pós-graduação.

Apesar da utilização da linguagem musical, os projetos e as aulas da professora tiveram como principal referência o livro didático. Ao ser utilizado pela professora em sua prática docente, o livro possibilitou leituras e contribuiu para a produção de narrativas na busca da compreensão, pelos alunos, dos temas em estudo. O livro se tornou uma referência 
das representações dos alunos, nas entrevistas, a partir de diferentes apropriações, apesar de destacarem a utilização de outras linguagens na sala de aula, como o desenho, o cinema e, principalmente, a música.

Outro aspecto importante em relação à prática da professora foi a sua preocupação constante com a disciplina, destacando-se estratégias para minimizar alguns problemas, procurando trabalhar com situações que aumentassem a auto-estima dos alunos, como discussão de textos e filmes fora da sala de aula que levassem o aluno a refletir sobre a sua prática e importância dentro da escola. Para a professora Marli, os temas comportamento e disciplina dos alunos estabeleceram uma forte representação da sua prática pedagógica, fazendo com que a linguagem musical, fosse vista como facilitadora das funções básicas da escola de construir e manter certos padrões de conduta social. Portanto a representação de competência da professora não está apenas em planejar estratégias e tarefas próprias, permeadas pela linguagem musical, reconhecidas pela comunidade escolar; mas também tem a ver muito mais com a capacidade de a docente prever, reagir e dar soluções às situações pelas quais transcorre o seu saber e fazer profissional num campo institucionalizado representado pela escola.

No campo escolar, a prática profissional da professora é estruturada por duas séries de condicionantes: os s ligados à transmissão da matéria (condicionantes de tempo, de organização sequencial dos conteúdos, das mediações utilizadas - como no caso da música -, de alcance de finalidades, de aprendizagem por parte dos alunos, de avaliação, etc.) e os ligados à gestão das interações com os alunos (manutenção da disciplina, gestão das ações desencadeadas pelos alunos, motivação da turma, etc.). Portanto, o trabalho docente no ambiente escolar consiste em fazer essas duas séries de condicionantes convergirem, em fazêlas colaborar entre si.

De caráter temporal, esses condicionantes - que fazem parte dos saberes formados pela ação da professora, o que lhe engloba a história de vida e a carreira profissional -, formam uma memória e uma consciência musical e histórica. Notei que, ao longo da observação e também através das repostas obtidas durante a entrevista, a prática pedagógica da professora mediada pela linguagem musical encontra-se ligada a um saber-fazer da construído por ela ao longo da sua trajetória de vida social e profissional.

A análise do discurso da professora evidencia algumas linhas de força dos seus percursos profissionais que levam a uma identidade como docente, processo que procuro analisar ao longo do capítulo sexto. Nesse processo de formação e identidade profissional, as expectativas pessoais e familiares se cruzam com as oportunidades e os constrangimentos 
institucionais e sociais da profissão. As tensas primeiras experiências como professora contribuem para modelar a identidade profissional até o desenvolvimento de diferentes linhas estruturantes do progressivo amadurecimento. Isso acaba evidenciado nas relações com os alunos, com os colegas, com o conhecimento e com a própria profissão.

As trajetórias pessoais e profissionais misturam se e estabelecem uma construção de identidades que passa sempre por um processo complexo pelo qual cada profissional se apropria do sentido da sua história pessoal e profissional. Trata-se, no entanto, de um processo que necessita de tempo. Tudo para construir e refazer identidades, para acomodar inovações, para assimilar mudanças. Esse processo identitário pelo qual passa a professora faz parte de uma historicidade inerente à construção da consciência musical e histórica dela, expressa-se e imprime-se nos saberes profissionais, e, mais especificamente, nos saberes experienciais adquiridos no início da carreira, que são, parcialmente, não só reativação, mas também transformação dos saberes adquiridos nos processos anteriores de socialização (familiar, escolar e universitária).

A história de vida da professora Marli é um exemplo único de gerir e organizar as energias interiores e exteriores. Nessa história de formação e desenvolvimento profissional, identifiquei processos parciais, grandes linhas de força de um processo mais global. Esses processos parciais não são linhas paralelas, mas reforçam-se e integram-se. Por vezes, começam como reações a circunstâncias provocadoras, ou são desencadeados por crises e situações dissonantes vividos em vias labirínticas, que não são vividas como rupturas com o passado, mas como novas aberturas que encadeiam as dimensões temporais que formam uma consciência musical e histórica que chegam à sala de aula.

A grande variedade de relações entre identidade pessoal e profissional estabelece uma atividade de autocriação e de transformação vividas entre a tensão e a harmonia, a distância e a proximidade, a integração e a desintegração. A professora é o elemento central, procura sempre a possibilidade de unificação, mas às vezes é atingida por múltiplas contradições e ambiguidades que, afinal, acabam auxiliando-a na construção da sua consciência musical e histórica, transformam-se em referencial para a prática pedagógica dela em sala de aula.

Em resumo, todas as reflexões propostas por esta pesquisa têm como principal referência a escolarização. Porém, mediada pela linguagem musical e através do ensino de história, leva em consideração o cotidiano escolar, o saber e as representações históricas dos seus principais personagens: professores e alunos. 


\section{CAPÍTULO 1- MÚSICA E CULTURA ESCOLAR: ESCUTA INDIVIDUALIZADA, INEXPRESSÃO CORPORAL E CULTURA DO SILÊENCIO}

O objetivo deste capítulo é estabelecer alguns pontos de reflexão sobre a relação entre música e cultura escolar a partir das observações ligadas às atividades de campo envolvendo seus agentes no processo de aprendizagem, mediado pela linguagem musical. Daí a importância da realização de uma descrição metódica e minuciosa, neste caso, dos processos de interação social no interior dos estabelecimentos escolares e das salas de aula apreendidos como microssociedades que possuem uma cultura singular (FORQUIN, 1992: 28).

A cultura escolar, aqui analisada, seria um sistema que dotaria os indivíduos de um corpo comum de categorias de pensamento. Cumpre, por isso, uma função de integração lógica, ao mesmo tempo, que de integração moral e social. Os espíritos assim modelados estão, pois, predispostos a entreter com seus pares uma relação de cumplicidade e de comunicação imediatas (FORQUIN, op. cit.: 36).

A relação entre música e cultura escolar será discutida em três aspectos: a veiculação das músicas durante a hora do intervalo; a música e a inexpressão corporal da chamada "aula pública" ; e o não fazer parte da cultura escolar da comunidade este projeto pedagógico coletivo. Essas reflexões procurarão responder a seguinte questão: como as práticas pedagógicas mediadas pela música interferem e transformam a cultura escolar?

\section{1- O som da hora do intervalo}

Durante a terceira visita à escola, a professora me apresentou à aluna Danila $\left(8^{\mathrm{a}} \mathrm{A}\right)$, uma das responsáveis pelo "som" da hora do intervalo. Assim, quando cheguei para a quarta visita, procurei a referida aluna, que me fez conhecer outros dois colegas da oitava série Fernando e Eric - responsáveis pela execução das músicas durante o intervalo. Esse espaço musical ainda só funciona no período da tarde e é monitorado pela auxiliar de direção Cristiane (ex-professora de Educação Artística que ocupa a função situada entre o assistente de direção e os inspetores da escola).

A semana, na ocasião, era dividida em um ritmo para cada dia: black: rap romântico internacional e rap nacional ( $2^{\mathrm{a}}$ feira); samba / pagode ( $3^{\mathrm{a}}$ feira); funk carioca e axé ( $4^{\mathrm{a}}$ feira); 
música eletrônica ( $5^{\mathrm{a}}$ feira); e novamente black ( $6^{\mathrm{a}}$ feira). Esses ritmos foram escolhidos entre os alunos do período da tarde no início do ano letivo, o que não impedia que outros ritmos pudessem ser executados na ausência de $c d s$ do ritmo do dia. Sem a disponibilidade dos $c d s$, sintoniza-se o rádio, na maior parte das vezes, na rádio Metropolitana $(98,5 \mathrm{MHz})$, que executa música negra internacional e pop nacional.

Geralmente os alunos da $7^{\mathrm{a}}$ e da $8^{\mathrm{a}}$ séries levavam os $c d s$, com maior frequiência durante o primeiro semestre. Esse espaço para audição de músicas não se encontra vinculado a nenhum projeto pedagógico e a execução das mesmas passa a ser encarada como som ambiente para a maior parte dos alunos, cuja maioria não presta atenção e nem se empolga com a execução delas.

Como os alunos escutam suas músicas (apêndice III - tabela 7)

\begin{tabular}{|c|c|}
\hline Aparelho portátil - walkman (fita cassete, $c$ player, ipod ou celular) & $75 \%$ \\
\hline Aparelho de som (fita cassete, $c d$, vinil ou mp3) & $53 \%$ \\
\hline Computador & $69 \%$ \\
\hline Rádio - Rádio do carro & $62 \%$ \\
\hline Televisão (vídeo ou $d v d$ ) & $50 \%$ \\
\hline Não especificou & $3 \%$ \\
\hline
\end{tabular}

Deve-se citar ainda um grupo de mais ou menos $20 \%$ dos alunos que utilizavam algum tipo de aparelho portátil com fones de ouvido (discman, ipod ou celulares). Essa tendência também se tornou evidente quando $75 \%$ dos alunos entrevistados da $5^{\text {a }}$ série - observada durante a pesquisa - declararam ouvirem suas músicas em algum tipo desses aparelhos portáteis citados.

Contato com os estilos musicais e artistas preferidos (apêndice III - tabela 6)

\begin{tabular}{|c|c|}
\hline Cinema & $3 \%$ \\
\hline Colegas & $37 \%$ \\
\hline Escola & $31 \%$ \\
\hline Família & $41 \%$ \\
\hline Internet & $50 \%$ \\
\hline Rádio & $62 \%$ \\
\hline Televisão & $50 \%$ \\
\hline Vídeo - DVD & $31 \%$ \\
\hline
\end{tabular}

Apesar dessa individualização da escuta, ao acolherem uma determinada obra musical em moda naquele momento, os alunos que participavam da constituição do repertório da rádio viviam o prazer, mesmo que de forma pontual, de superar algumas diferenças que os 
separavam e os obstáculos que os opunham. Ocorria, assim, um momento de troca e divulgação de informações culturais entre eles, mesmo que a recepção destas informações fosse feita de forma individualizada. Muitos alunos apontaram os colegas (37\%) e a escola (31\%) como responsáveis pelos contatos iniciais com os estilos musicais e artistas preferidos.

Em relação à questão da música na escola, a professora Marli fez as seguintes observações durante a sua entrevista (apêndice VIII - quadro 24):

- "Na escola continua a rádio e a escuta individualizada (mp3, mp4 e celulares)".

- "A rádio serve para socializar os gostos dos alunos, às vezes peço para eles levarem as suas musicas para a sala de aula".

- “Às vezes eles levam musicas que se referem às musicas e aos artistas trabalhados em sala de aula, que muitas vezes eles escutam e baixam do computador, com o mp 3 não existe mais a cultura do disco".

- "As músicas que os alunos trazem não têm quase letra e sim ritmos e batidas eletrônicas que vêm do funk".

A fala da professora evidencia que a escuta se torna cada vez mais individualizada por causa dos meios digitais, o que também tornaria a música contemporânea cada vez mais marcada por ritmos e batidas eletrônicas. A rádio na escola e a solicitação para que os alunos trouxessem músicas para a sala de aula seriam uma forma de se opor a essa individualização a partir da socialização da escuta, procurando retomar a cultura da escuta coletiva, como na época do disco de vinil.

A prática e o discurso da professora revelam que, na comunicação cotidiana contemporânea, com meios de comunicação cada vez mais individualizados ${ }^{5}$, nós e nossos alunos estamos correndo o risco de ficarmos mais fechados em nós mesmos, e a escola reafirma essa maneira de ser. A música inserida isoladamente sem um projeto pedagógico efetivo, apenas legitima ainda mais esse aspecto individualista da cultura escolar contemporânea, mesmo nos momentos coletivos de alegria, como em festas, shows, festivais, ou qualquer outro tipo de evento na escola que envolva música.

\footnotetext{
5 "É isso que distingue a 'individualização' de outrora da forma que ela assumiu agora, em nossos tempos de modernidade 'liquida'. As colocações individuais na sociedade e os lugares aos quais os indivíduos podem ganhar acesso e nos quais podem desejar se estabelecer estão se derretendo com rapidez e dificilmente podem servir como alvos para "projetos de vida" (BAUMAN, 2008:185).
} 
“(...) É por isso que a alegria da comunicação musical pode e deve evitar o perigo da perda de si mesma numa vertigem comum, num transe coletivo no qual gostaríamos de deixar de ser nós mesmos, sem dúvida na esperança de escapar às dificuldades pessoais que não nos sentimos capazes de superar" (SNYDERS, 1997: 92).

Cabe à escola fazer o aluno perceber em quais condições a comunicação musical pode escapar do risco de se transformar de linguagem individualizada em movimento simultâneo de conjunto e retorno a si mesmo, entusiasmo de um grupo e reflexão individual. Os alunos podem aprender a viver um sentimento de compartilhar experiências sonoras do indivíduo com o grupo que resulte num aprendizado do aluno e da turma: cada ouvinte interpreta a emoção da experiência musical do seu próprio jeito e, ao mesmo tempo, participa das reações dos colegas, a tal ponto que se torne possível a formação de uma cultura musical escolar marcada pela pluralidade.

\section{“Aula pública": música e inexpressão corporal}

A nona semana de observação foi dedicada à segunda "aula pública", que é um momento de apresentação coletiva dos trabalhos dos alunos para todas as turmas da escola do período da tarde. A professora também ressaltou o fato de esse evento ter sido introduzido naquele ano com o tema "Meio ambiente".

O tema da "aula pública" era a "Cultura afro-brasileira" em comemoração ao dia da Consciência Negra. As classes organizaram a apresentação nas três primeiras aulas do dia. Durante a organização da apresentação do evento, a aparelhagem de som do pátio executava músicas influenciadas por ritmos negros: samba, axé, rap e reggae.

Após o intervalo, as turmas deveriam retornar para as suas salas, depois cada uma deveria passar e observar a sala de exposições (sala seis no primeiro andar). Em seguida, cada aluno deveria pegar a sua cadeira e se dirigir ao pátio da escola onde aconteceriam as apresentações da "aula pública”. A exposição e a as apresentações foram também resultados da visita ao Museu Afro Brasil, localizado no Parque do Ibirapuera, no mês setembro. A sala de exposições era composta por painéis de cartolina que destacavam religião, arte, culinária e, principalmente, a escravidão negra no Brasil. Os painéis relativos à arte e à culinária africana eram das quintas séries. Também observei quatro maquetes: duas de engenho de açúcar e duas de navio negreiro, essas duas últimas eram as que acabavam despertando maior curiosidade 
dos alunos. Segundo a professora Marli, os trabalhos haviam sido concluídos em sala de aula na semana anterior.

Após cada sala passar pela exposição, os alunos se acomodaram no pátio com as respectivas cadeiras e houve o início da chamada "aula pública”. O palco era decorado com painéis alusivos à cultura africana complementados pela projeção de imagens da África Negra com datashow em uma tela ao lado do palco. A abertura e a apresentação do evento foram feitas pelo coordenador pedagógico Cláudio - de ascendência negra - vestido com roupa jamaicana e típica de festa da nobreza nagô. O coordenador contou com a colaboração do aluno negro Eric ( $\left.8^{\mathrm{a}} \mathrm{A}\right)$ na leitura do texto de abertura, que também estava vestindo uma roupa típica emprestada pelo coordenador Cláudio Essa leitura foi precedida por uma música de abertura, um reggae do grupo Cidade Negra, intitulado “Ancestrais” (2004), falando sobre a identidade do negro hoje através do seu passado de sofrimento e discriminação.

A apresentação seguiu com vários jograis de alunos de todas as séries recitando diversos temas: a visita ao museu Afro Brasil, a escravidão negra, Zumbi dos Palmares, a arte e a religião africana (apenas a tribal), as semelhanças naturais e sócio-culturais entre a África Negra e o Brasil. Um esquete sobre a escravidão com a participação do coordenador Cláudio como "capitão do mato" antecedeu o jogral da oitava série. Em geral, projeções de imagens com datashow acompanhavam a apresentação dos jograis.

A professora Marli chegou após uns trinta minutos do início das apresentações, pois tinha consulta médica. Todas as vezes que alunos da quinta série se apresentavam, ela me explicva e ressaltava os aspectos positivos dos trabalhos apresentados. Caberia a professora Marli a apresentação coletiva dos alunos das quintas e sextas séries da música "Pacato Cidadão" (1994) do grupo Skank, que fala da passividade do cidadão diante dos problemas gerados pela civilização. Durante a execução dessas séries, os alunos das demais séries se agitaram, levantaram ou ficaram em pé sobre as cadeiras, mas poucos cantaram.

Após a apresentação, a professora me confidenciou que gostaria de que a apresentação encerrasse o evento, pois, para ela, a apresentação teria mais entusiasmo e participação de todos, iria fazê-la sentir-se uma pop star. Na realidade, os alunos ficaram mais dispersos e não prestaram atenção em mais nada. Esse comportamento constante ocorreu principalmente durante os jograis. Por isso, houve várias intervenções tanto do coordenador através do microfone quanto dos professores na platéia para que os alunos fizessem silêncio. 
"As festas, que são grandes momentos de comunicação, e os concertos, tomados verdadeiras manifestações de massa, exprimem e assim exaltam os sentimentos coletivos, dando existência concreta à aspiração pelo coletivo" (SNYDERS, 1997: 88).

Os eventos pedagógicos coletivos mediados pela música constituem um momento privilegiado para que os alunos se coloquem de forma uníssona com os outros. Trata-se de um momento de escuta recíproca, com as habituais ressonâncias e ruídos que em geral não são bem assimilados pela cultura escolar baseada no silêncio, mas que provocam momentaneamente uma identidade para o corpo discente.

Apesar das reclamações em relação ao barulho, a apresentação continuou com os jograis e outras músicas, como foi o caso de um jogral da $8^{\mathrm{a}} \mathrm{B}$ sobre escravidão que encerrou com uma projeção de imagens sobre o tema e a canção "Retirantes" (1976) de Dorival Caymmi, tema de abertura da novela "Escrava Isaura" produzida pela TV Globo. Outra apresentação musical foi a de dois alunos da $8^{a}$ A que cantaram o rap "Negro Drama" (2002) dos Racionais $M C$ 's, utilizando apenas a base rítmica original da música. Essa canção fala do racismo e da discriminação em relação aos negros da periferia. A professora Marli, ao me indagar se a música era dos dois alunos, evidenciou desconhecimento da autoria.

Antes do final do evento, o coordenador Cláudio agradeceu a todos pelo empenho e pela a participação. Destacou que os trabalhos não apresentados naquele evento seriam posteriormente exibidos na mostra cultural da escola, intitulada "São Paulo espaço e memória", a ser realizada no primeiro sábado de dezembro. Com isso, reforçou o convite aos alunos e respectivas famílias para que comparecessem ao evento.

A "aula pública" foi encerrada com a apresentação de quatro alunas $\left(5^{\mathrm{a}}, 6^{\mathrm{a}}\right.$, e $7^{\mathrm{a}}$ séries) dançando um samba instrumental, coreografado pela professora de Educação Artística. Enquanto isso, os alunos se retiravam rapidamente do pátio com as cadeiras, pois faltavam cinco minutos para bater o sinal da saída. Cabe ressaltar que o evento também foi acompanhado pela diretora da escola e fotografado pela professora Suelen, de Geografia.

Apesar do encerramento da aula pública com uma coreografia, constatei a ausência de expressão corporal e a dissociação do corpo em relação à prática musical. Ta lvez a utilização mais constante da expressão corporal pudesse facilitar ainda mais a compreensão e o significado das músicas trabalhadas durante o evento.

A memória e a compreensão musical assentam num mapa cerebral fortemente marcado pelas representações de um corpo que interage com a música de forma muito generalizada e diversificada. Isso foi comprovado pelos resultados de várias pesquisas na área 
da pedagogia, da psicologia e da neurociência ao longo do último século.

"O movimento corporal, seja ele o resultante da execução instrumental ou a mímica em estreita relação com o caráter expressivo e as várias seções da música, constitui como elemento fundamental do conhecimento musical que vai muito além do que pode ser verbalmente articulado" (GODINHO, 2006: 92).

A visão tradicional sobre o papel desempenhado pelo corpo na experiência musical tem oscilado entre a pouca importância que lhe é atribuída ou o valor utilitário e subserviente que o relega para uma função de suporte ${ }^{6}$. Apesar do esforço de alguns teóricos e educadores em valorizar o movimento e a expressão corporal na aprendizagem musical, essa defesa tem, no entanto, acentuado uma implícita separação entre corpo e mente. Segundo GODINHO, (2006: 375), o corpo apresenta-se como indispensável na execução musical, mas, embora vista como promotora da melhoria da competência musical, esta relação é interpretada por meio de processos de transferência de saberes ou capacidades de diferentes naturezas

Não cabe aqui identificar as relações entre o movimento corporal e a compreensão musical, entre o corpo e a mente musical. No entanto, chama-se a atenção para a importância que o corpo desempenha no desenvolvimento da compreensão musical, quer por meio do movimento de dança ou expressão corporal, quer por meio da movimentação associada à produção sonora através de instrumentos que deve se fazer mais presente nos projetos pedagógicos, algo que também não é destacado pela professora em relação à sua prática pedagógica.

Considerando as observações e reflexões com relação ao espaço escolar, ao mesmo tempo em que a escola funciona como repressora e disciplinadora dos corpos dos sujeitos, através de seus rituais e normas, pode também configurar-se como um dos importantes instrumentos de transformação. Isso se ultrapassar essa concepção instrumentalizadora do movimento da qual resulta condicionamento ou imobilismo dos alunos, que, muitas vezes, reagem com indisciplina.

Tradicionalmente, a escola mantém o corpo sob controle no cotidiano, pois as diversas estratégias metodológicas regularmente apontam para o imobilismo, para a construção do conhecimento priorizado no aspecto cognitivo, pouco atento às expressões corporais e aos

\footnotetext{
${ }^{6}$ Foucault evidencia a descoberta do corpo como objeto e alvo de poder, no século XVIII. Para ele, "o momento histórico das disciplinas é o momento em que nasce uma arte no corpo humano, que visa não unicamente o aumento de suas habilidades, nem tampouco aprofundar sua sujeição, mas a formação de uma relação que, no mesmo mecanismo, o torna tanto mais obediente quanto é mais útil, e inversamente" (FOUCAULT, 1987:127).
} 
movimentos construídos pelos alunos, que traduzem um conjunto acumulado de conhecimento, cultura e história. Assim, a escola, enquanto instituição social, auxilia na manutenção da hierarquia de poder, reforçando estruturas sociais pouco focadas em mudanças.

Após o término do evento, indaguei a professora Marli sobre o entusiasmo e o envolvimento do coordenador Cláudio em relação às apresentações. Ela disse que ele era ligado a um grupo religioso afro e também fazia parte de um grupo de estudo sobre cultura africana ligado à Universidade de São Paulo. A professora entusiasmada também ressaltou o fato de esse evento ter sido introduzido naquele ano. Ela se colocou como uma das pessoas que ajudaram a introduzir eventos públicos na escola desde 2005 - o primeiro havia sido uma apresentação sobre identidade nacional -, incentivando o coordenador pedagógico Cláudio a inserir esse tipo de prática pedagógica coletiva. Segundo a professora, até então "a escola era muito calada. A partir de então e ainda paulatinamente, os alunos estavam se acostumando a esse tipo de prática pedagógica coletiva", procurando justificar, em parte, o comportamento dispersivo dos alunos durante as apresentações.

Ainda em relação a esse evento, a professora, durante a entrevista, fez as seguintes observações (anexo VI - tabela 24):

- "O coordenador Cláudio saiu da escola no ano passado (2008) e o projeto da 'aula pública', que foi trazido por mim e ampliado pelo coordenador em 2007, terminou."

- “Com o fim do projeto a 'aula pública' permaneceu uma ação isolada, quando apresento as músicas com os alunos no pátio, nos vinte minutos finais da última aula, em uma data pré-determinada pela direção da escola".

O papel da professora Marli e do coordenador Cláudio durante a "aula pública" provoca um mergulho na análise da trajetória de vida dos docentes envolvidos. Procuro encontrar, à luz dos conceitos de capital cultural e habitus de BOURDIEU (2001:74-75), a compreensão para os comportamentos dos professores durante essa prática pedagógica.

Para ele, o capital cultural sob a forma de estado incorporado pressupõe um trabalho de inculcação e assimilação. É um ter que se tornou ser, uma propriedade que se fez corpo e tornou-se parte integrante da pessoa, um habitus. O capital cultural constrói um ethos, sistema de valores implícitos e profundamente interiorizados, que contribui para definir, entre outras, as atitudes face ao capital cultural e à instituição escolar. 
O habitus é produto de toda a experiência biográfica do indivíduo e funciona como um sistema de esquemas geradores de estratégias que podem, objetivamente, servir aos interesses de seus autores. No caso da professora Marli isso pode ser caracterizado pelo fato de a comunidade escoar reconhecê-la como uma docente competente e identificada com práticas pedagógicas ligadas à música, enquanto o coordenador Cláudio também era reconhecido como um educador que fazia parte de grupos culturais e religiosos de cultura africana. Portanto, o capital cultural dos dois, considerado como um conjunto de recursos ligados à posse de uma rede durável de relações, garante que os agentes se reconheçam como pares e possam fazer parte de um determinado grupo caracterizado, nesse caso, pela comunidade escolar.

A ação pedagógica, dessa forma, reside no poder de comandar a prática tanto ao nível inconsciente -por meio dos esquemas constitutivos do habitus cultivado - como ao nível consciente, através da obediência aos modelos explícitos. Portanto, para BOURDIEU (apud Miceli, 2003: XL - XLI), o habitus como sistema de disposições para a prática é um fundamento objetivo de condutas regulares, da regularidade das condutas e, se é possível prever as práticas é porque o mesmo faz com que os agentes que o possuem comportem-se de determinada maneira em determinadas circunstâncias.

Sendo produto da incorporação da necessidade objetiva que pode se tornar virtude, o habitus produz estratégias que se mostram objetivamente ajustadas à situação, algo que, pelas minhas observações, não aconteceu durante as apresentações da "aula pública", principalmente quando não havia música, pois, como já comentei, a tendência era que os alunos ficassem cada vez mais dispersos e não prestassem atenção em mais nada. Esse comportamento constante, principalmente durante os jograis, provocando várias intervenções do coordenador devido à desconcentração dos alunos.

\section{O fim da "aula pública" e a cultura do silêncio}

A prática da "aula pública" e da cultura do silêncio não se perpetuaram em um habitus da comunidade escolar em elementos constitutivos da cultura da escola por alguns motivos. Em primeiro lugar, porque o capital cultural dos dois principais docentes envolvidos do projeto se manteve apenas no estado objetivado (capital cultural sob a forma de bens culturais que pode ser transmitido para outra pessoa, tais como: livros, painéis de cartolina, maquetes, aparelho de som, datashow etc.) e no estado institucionalizado (capital cultural consolidado através dos títulos, certificados escolares e da prática institucionalizada dos dois docentes 
envolvidos no projeto pedagógico), faltando a base para a constituição de um habitus escolar que é o estado incorporado.

O estado incorporado é o capital cultural que se apresenta ligado ao corpo, o que pressupõe a incorporação por meio de um trabalho de inculcação e assimilação. Esse trabalho de aquisição do capital cultural leva um longo tempo e supõe um esforço do aluno e do docente sobre si mesmo. Aquele que adquire esse tipo de capital paga com o próprio esforço e com aquilo que tem de mais pessoal: seu tempo. A incorporação do capital cultural demanda tempo, daí não poder ser transmitido por doação, hereditariedade, compra ou troca de bens materiais. A inculcação e a assimilação do capital cultural só podem acontecer, segundo BOURDIEU (2001:74-75), através do investimento pessoal do receptor que, no nosso caso, seriam os alunos e demais docentes envolvidos no projeto "aula pública".

Um segundo ponto importante, que contempla a resposta para o fim desse projeto na escola encontra-se nas próprias observações da professora Marli em relação ao projeto e a música no âmbito da cultura escolar (apêndice VIII - quadro 24):

- "A escola era muito calada e os alunos estão se acostumando a esse tipo de prática pedagógica coletiva”.

- "A música ainda é vista como barulho na escola, o que, algumas vezes, motiva reclamações dos outros professores".

- "A cultura escolar ainda é vista como a cultura do silêncio, o professor e a sua aula expositiva com os alunos escutando sentados em silêncio".

As observações da professora evidenciam que a cultura do silêncio ainda é um elemento importante no contexto do capital cultural e do habitus da escola e que o projeto pedagógico não conseguiu romper. O habitus, enquanto sistema de disposições para a prática, fundamenta de forma objetiva as condutas regulares da comunidade escolar. É, pois, a regularidade das condutas determinadas pelos habitus que faz com que os agentes (alunos, docentes e funcionários) se comportem de uma determinada maneira, em determinadas circunstâncias, o que possibilita prever as práticas. Contudo, a tendência para agir de uma maneira regular não se origina nem se embasa numa regra específica ou, de forma explícita, numa lei, mas nas condutas geradas pelo habitus que se fundamenta em práticas isoladas, individualizadas e na manutenção do silêncio. 
Quanto mais instável e nova for a situação, mais a prática tenderá a ser codificada. Assim, em situações carregadas de agitação e ruído em potencial ${ }^{7}$, como no caso da "aula pública descrita", as condutas regidas pelas improvações do habitus são substituídas por condutas formalizadas e reguladas, que devem seguir um ritual metodicamente instituído e ao mesmo tempo codificado. A codificação permite acabar com o fluido, o vago, as fronteiras mal traçadas. Ela possibilita, através de cortes nítidos, que os limites sejam bem definidos. A codificação está, dessa forma, intimamente ligada à disciplina e à normalização das práticas. Algo que pode ser exemplificado pela declaração da professora Marli (anexo VI - tabela 24):

“Com o fim do projeto, a 'aula pública' permaneceu como uma ação isolada, quando apresento as músicas com os alunos no pátio, nos vinte minutos finais da última aula, em uma data pré-determinada pela direção da escola”.

Apesar da continuidade da prática musical da professora Marli, o silêncio continuou sendo a condição absoluta na dinâmica da escola. Essa modalidade segue ainda os parâmetros de educação tradicional baseada na hierarquização e na individualidade, em que, de uma forma explícita ou implícita, ainda se constitui um modelo de educação almejada ou aclamada por essa comunidade e que lhe fundamente a cultura escolar.

Acredito que três pontos analisados fizeram parte da cultura escolar dessa escola: a escuta individualizada, a inexpressão corporal e a preservação da cultura do silêncio. Demonstraram que as práticas pedagógicas individuais ou coletivas mediadas pela música são válidas como elementos motivadores para uma nova postura da comunidade em relação ao processo de ensino-aprendizagem e interferem positivamente na cultura escolar, mas isso não assegura a transformação, pois a utilização da linguagem musical apenas estabeleceu estratégias e perspectivas de transformação, mas não garantiu de forma objetiva as condutas regulares da comunidade escolar que alterariam o habitus da cultura escolar, que só poderia ocorrer através do envolvimento da maioria dos agentes envolvidos no processo de aprendizagem, pressupondo um trabalho de inculcação, assimilação, a partir de tempo e esforço da maioria da comunidade escolar.

\footnotetext{
7 "O ruído é mais rústico que o som, tecnicamente falando, pois é vibração sem ordem. O som é vibração organizada e mostra características definidas, que podem ser trabalhadas em conjunto com outros sons, gerando uma melodia, por exemplo (...) O ruído é feito de vibrações desorganizadas, em que cada aspecto do espectro vibratório não se realiza plenamente, em que as interferências entre as ondas vibratórias se acavalam e perturbam, sem estabelecer relação harmoniosa" (QUEIROZ, 2000:36).
} 


\section{CAPÍtULO 2- A MÚSICA COMO LINGUAGEM AFETIVA TRANSFORMADA EM CONSCIÊNCIA}

Como demonstrei no capítulo anterior, as práticas pedagógicas mediadas pela música podem transformar a cultura escolar, que também é influenciada pelos gostos musicais dos alunos e da professora. Por sua vez, são identificados, na pesquisa, a partir da aplicação de questionários sobre o perfil discente e docente em relação às atividades musicais.

Foram aplicados 32 questionários para os alunos de uma sala de $5^{\mathrm{a}}$ série com idades que variavam entre 11 (75\%) e 13 anos (apêndice III - tabela 1). Os dados fornecidos por esse instrumento de pesquisa auxiliam na análise das observações em relação à memória e a consciência dos alunos mediadas pela linguagem musical, que são influenciadas por outros fatores como: a cultura de consumo e a identidade cultural em relação ao mundo contemporâneo, através da estetização da vida cotidiana; o desenvolvimento das tecnologias digitais e a escuta individualizada; a mediação afetiva da música na família e no cotidiano e o gosto musical como representação afetiva da realidade que se transforma em consciência musical.

\section{Música, cultura de consumo e estilo de vida}

A variedade apresentada pela tabulação de dados em relação aos tipos de músicas e artistas citados pelos alunos (apêndice III - tabela 3) mostra como a indústria cultural realiza a sua função de criar necessidades artificiais de consumo e formar vínculos sociais em torno deste mesmo consumo ao promover momentos de relaxamento e descanso em oposição ao mundo do trabalho e da escola, reforçando imagens estereotipadas e conservadoras, de fácil acesso a todos. Ao reprimir e recalcar a imaginação oferecendo cultura sem esforço, a indústria cultural trata a música como mercadoria.

Em seus textos "Sobre a música popular" (1947) e "O fetichismo na música e a regressão da audição” (1963), ADORNO apresenta uma análise minuciosa da música como produto da indústria cultural e das razões de sua influência sobre os ouvintes. Segundo o filósofo, o traço distintivo desta música é a estandardização, ou seja, a padronização que vigora como regra geral de produção e de audição da música. Os padrões musicais populares, ainda segundo ADORNO, desenvolveram-se originalmente pela competição. Portanto, 
quando surge um sucesso, aparecem centenas de músicas imitando o hit inicial (Adorno, 1986: 121). Isso explicaria porque os ritmos como funk, black, pagode/samba e axé foram citados com maior frequência pelos alunos nos questionários aplicados, pois eram os ritmos musicais mais executados pelos meios de comunicação.

Tipos de música e artistas preferidos (apêndice III - tabela 3)

\begin{tabular}{|c|c|c|}
\hline Axé & $19 \%$ & Babado Novo - Claudia Leite (3) e Ivete Sangalo (3). \\
\hline Black & $34 \%$ & $\begin{array}{c}\text { Akon (4), Rihanna (3), Nelly Furtdo (2), } 50 \text { Cent (1), Justin } \\
\text { Timberlake (1). }\end{array}$ \\
\hline Clássica / Erudita & $0 \%$ & \\
\hline Forró & $9 \%$ & Bonde do Forró (1) e Camisa Suada (1). \\
\hline Funk & $59 \%$ & $\begin{array}{c}\text { Menor do Chapa (4), Claudinho \& Bochecha (3), Mc Katia (3), } \\
\text { Mc Naldinho (2), Mc Perlla (2), DJ Malboro (1), Mc Leozinho } \\
\text { (1), Mc Magrela (1), Mc Rose (1), Mc Sabrina (1), Mc Sapão } \\
\text { (1), MC's B1 \& B2 (1). }\end{array}$ \\
\hline Gospel / Religiosa & $16 \%$ & Ana Paula Valadão (1), Cristina Mel (1), Kleber Lucas (1). \\
\hline MPB & $22 \%$ & $\begin{array}{c}\text { Guilherme Arantes (4), Alceu Valença (1), Ana Carolina (1), } \\
\text { Elis Regina (1), Fagner (1), Vanessa da Mata (1). }\end{array}$ \\
\hline Pagode / Samba & $25 \%$ & $\begin{array}{l}\text { Exaltasamba (4), Jeito Moleque (4), Inimigos da HP (2), Jorge } \\
\text { Aragão (1), Sorriso Maroto (1), Zeca Pagodinho (1). }\end{array}$ \\
\hline Pop / Rock & $53 \%$ & $\begin{array}{c}\text { Legião Urbana (2), Nx Zero (2), Pitty (2), Backstreet Boy (1), } \\
\text { Black Sabbath (1), Fresno (1), Ira (1), Latino (1), Lulu Santos } \\
\text { (1), Queen (1), Raul Seixas (1), Sandy \& Junior (1), Simple } \\
\text { Plan(1), Strike (1), Vanessa Camargo (1). }\end{array}$ \\
\hline Rap & $16 \%$ & $\begin{array}{l}\text { Racionais Mc’s (5), Ao Cubo (3), Expressão Ativa (3), Facção } \\
\text { Central (2), Sabotagem (1). }\end{array}$ \\
\hline Sertanejo & $9 \%$ & $\begin{array}{c}\text { Daniel (1), Grupo Tradição (1), Rick \& Renner (1), Rio Negro } \\
\text { \& Solimões (1), Victor \& Leo (1). }\end{array}$ \\
\hline
\end{tabular}

No entanto, essa tese não se aplicaria aos outros ritmos citados pelos alunos. O pop/rock, a MPB e o rap, por exemplo, ritmos e estilos dos quais a maioria dos artistas citados não possuía hits nos meios de comunicação no momento da aplicação dos questionários. Esse fato evidencia que a forte influência dos meios de comunicação é limitada por outros fatores como a família, os colegas e a escola.

Contato com os estilos musicais e artistas preferidos (apêndice III - tabela 6).

\begin{tabular}{|c|c|}
\hline Cinema & $3 \%$ \\
\hline Colegas & $37 \%$ \\
\hline Escola & $31 \%$ \\
\hline Família & $41 \%$ \\
\hline Internet & $50 \%$ \\
\hline Rádio & $62 \%$ \\
\hline Televisão & $50 \%$ \\
\hline Vídeo - DVD & $31 \%$ \\
\hline
\end{tabular}


ADORNO (1983:165) classificou os hábitos de audição contemporâneos de regressivos, pois não haveria autonomia individual na relação com a música popular, que foi aceita sem resistência . Na música, até os improvisos seguem uma norma. Como não é preciso fazer esforço para ouvir as músicas padronizadas, é a distração que orienta os hábitos de audição. Ocorre uma pseudo-individuação sociológica (e não técnica) até das peças musicais ao se enfatizar os tipos de música e os conjuntos que tocam, o que configura uma técnica de rotulação que providencia marcas comerciais de identificação para diferenciar o que não é diferente16. As próprias letras das músicas não passariam de slogans comerciais.

Como, em decorrência da estandardização (exigida pelo mercado), as músicas são semelhantes entre si e, devido ao fato de serem mercadorias (sem vínculo real com os indivíduos além do comércio), a Indústria Cultural lança mão de alguns artifícios para dar relevância às canções e incentivar-lhe o consumo, conferindo um caráter fetichista à música, que passa a ser gostada como se possuísse existência própria e criando a ilusão de identificação com o ouvinte. A promoção é um deles: a repetição incessante de um hit nas rádios e na TV quebra a resistência ao musicalmente idêntico e as reações habituais tornam-se automatizada. Não só as músicas são promovidas desse modo, mas as personalidades e os estilos também. A repetição dá ao hit importância psicológica, força a recordação, impõe o material musical, complementando a estandardização. Assim, qualquer música pode ser um sucesso, desde que tenha o apoio das agências de divulgação e promoção, tenha um detalhe diferente das outras e a mesma estrutura dominante.

Mas existe uma característica desse processo que levou ADORNO (1986:144-145) a crer que a aceitação da música não se dá de forma totalmente passiva: a ambivalência dos hábitos de audição. O "gostar" de determinado hit ou de certo artista está sempre a um passo de degenerar em fúria e despeito ao mesmo. Aquilo que é moda agora, amanhã corre o risco de ser ridicularizado. Como a mercadoria musical é aceita e venerada devido à imposição que é feita pelas agências de promoção, e porque os ouvintes no fundo sentem que estão sendo enganados pela indústria cultural, assim que essa pressão se arrefece, o despeito pode surgir. Esse é um sinal de que os ouvintes precisam transformar as ordens externas em ordens internas, pois teriam que se forçar a aceitar.

Daí a importância da reflexão sobre a indústria cultural e o papel da música popular. Quanto mais estivermos conscientes desse contexto, talvez maiores as oportunidades de libertação do prazer controlado. Se a aceitação necessita da vontade é porque há ainda alguma viva, que sob certas circunstâncias, pode ser forte o suficiente para livrar os indivíduos das influências impostas, mesmo porque esses hits, também são registros históricos de uma época, 
que estabelecem um referencial de memória na vida de cada indivíduo e que, com o passar do tempo, podem gerar uma futura reflexão sobre o padrão de consumo musical em relação aos modismos impostos pela indústria cultural. Algo que pode ser exemplificado pelos tipos de ritmos e artistas citados pela professora Marli.

Tipos de música e artistas preferidos (apêndice VIII - quadro 4)

\begin{tabular}{|c|c|}
\hline Axé & \\
\hline Black & Mozart. \\
\hline $\begin{array}{c}\text { Clássica / } \\
\text { Erudita }\end{array}$ & Luiz Gonzaga. \\
\hline Forró & \\
\hline Funk & \\
\hline Gospel / & \\
\hline Religiosa & Maetano Veloso, Chico Buarque, Zizi Possi, Gal Costa, Maria Bethânia e \\
\hline MPB & Marisa Monte. \\
\hline Pagode / Samba & Mey Matogrosso e Secos \& Molhados, Legião Urbana, Raul Seixas, Rita Lee, \\
\hline Pop / Rock & \\
\hline Rap & \\
\hline Sertanejo & \\
\hline Outros & \\
\hline
\end{tabular}

Vários artistas citados pela professora fizeram sucesso comercial nas décadas de 60 (The Beatles, Chico Buarque, etc.), 70 (Secos \& Molhados, Raul Seixas, etc) e 80 (Titãs, Legião Urbana, etc.). Transformaram-se em registros pessoais de uma época, estabelecendo um referencial de memória na vida da professora, que, com o passar do tempo, gerou uma futura reflexão sobre o padrão de consumo musical em relação aos modismos impostos pela indústria cultural nos dias de hoje, bem como uma valorização de artistas que foram sucesso de gerações anteriores (Luiz Gonzaga, Tonico \& Tinoco, Inezita Barroso e Nelson Gonçalves).

Os dados da pesquisa não confirmam uma avaliação apenas negativa dos prazeres do consumo, herdada da teoria da cultura de massa explicada por ADORNO (1986). Abre a perspectiva sobre três ideias sobre a música como bem de consumo (FEATHEERSTONE, 1995: 31). A primeira é a de que a música como cultura de consumo tem como premissa 
apenas a expansão da produção capitalista de mercadorias. Isso deu origem a uma vasta acumulação de cultura material na forma de bens e locais de compra e consumo. Resultou ainda na proeminência cada vez maior do lazer e das atividades de consumo nas sociedades ocidentais contemporâneas, fenômenos que, embora sejam bem-vistos por alguns, na medida em que têm resultado em maior igualitarismo e liberdade individual, são considerados por outros como alimentadores da capacidade de manipulação ideológica e controle sedutor da população, através da massificação promovida pelos meios de comunicação de massa, prevenindo, qualquer alternativa "melhor" de organização das relações sociais.

Em segundo lugar, o gosto, propensão e aptidão à apropriação material e/ou simbólica de uma determinada categoria de objetos ou práticas relacionadas a eles que, no nosso caso, se refere à música é o que gera o princípio do estilo de vida. Conjunto unitário de preferências distintivas que exprimem uma lógica de vida de cada aluno formando subespaços simbólicos resulta em variações da distância com o mundo (pressões materiais e urgências temporais), que depende, ao mesmo tempo, da urgência objetiva da situação no momento considerado e da disposição para tomar suas distâncias em relação a essa situação (ORTIZ, 1983: 83-84). E é justamente essa distância e a mediação com o mundo feita através da música, que se encontra associado ao estilo de vida dos alunos, um dos aspectos importantes desta pesquisa.

Essa concepção mais estritamente sociológica é exemplificada por BOURDIEU (2001). A relação entre a satisfação proporcionada pelos bens e seu acesso socialmente estruturado é um jogo de soma zero, no qual a satisfação e o status dependem da exibição e da conservação das diferenças, destacando o fato de que as pessoas usam as mercadorias de forma a criar vínculos ou estabelecer distinções sociais ${ }^{8}$.

Finalmente, vem a questão dos prazeres emocionais dos bens de consumo. Os sonhos e os desejos celebrados no imaginário cultural consumidos em locais específicos, produzem diversos tipos de excitação física e prazeres estéticos construindo assim determinadas representações que farão parte do imaginário juvenil.

Esta pesquisa argumenta que é importante focalizar a questão da proeminência cada vez maior da cultura de consumo, e não simplesmente considerar que o consumo deriva inequivocamente da produção. A fase atual, de oferta excessiva e bens simbólicos nas

\footnotetext{
8 “Às diferentes posições no espaço social correspondem estilos de vida, sistemas de desvios diferenciais que são a retradução simbólica de diferenças. objetivamente inscritas nas condições de existência. As práticas e as propriedades constituem uma expressão sistemática das condições de existência (aquilo que, chamamos estilo de vida) porque são o produto do mesmo operador prático, o habitus, sistema de disposições duráveis e transponíveis que exprime, sob a forma de preferências sistemáticas, as necessidades objetivas das quais ele é o produto (...)" (ORTIZ, 1983:82).
} 
sociedades ocidentais contemporâneas, e as tendências para desclassificação e desordem cultural (que alguns rotulam de pós-modernismo) estão, portanto, colocando em evidência as questões culturais e têm implicações mais amplas em nossa conceituação do relacionamento entre cultura, economia e sociedade.

Esses fenômenos têm resultado ainda num interesse cada vez maior por conceituar questões de desejo e prazer. As satisfações emocionais e estéticas são derivadas das experiências de consumo, revelando um estilo de vida, não simplesmente em termos de alguma lógica de manipulação psicológica, ou apenas da confirmação de uma avaliação negativa dos prazeres do consumo da teoria da cultura de massa.

\section{Escuta individualizada, família e mediação afetiva}

A globalização e a estetização da vida cotidiana encontram-se presentes na realidade, no pensamento e no imaginário de todos, atingindo coisas, pessoas, ideias, sociedades, nações, culturas e civilizações. Esses processos possibilitam troca de experiências artísticas, musicais, tecnológicas, culturais e estéticas, facultando mudanças ligadas à tecnologia.

A eletrônica, a informática e a telecomunicação invadiram atividades e relações de todo o mundo, modernizando formas de imaginar (mais do que de sentir) e modos de agir (mais do que de pensar). Inauguraram-se novas formas narrativas baseadas na montagem, na bricolagem, na colagem, no simulacro e no vídeo que temos de levar em consideração ao analisarmos as representações dos alunos durante as entrevistas. Como a globalização articula ausência de fronteiras, a diversidade de cultura, particularmente no campo da arte e da música, acaba por assumir relevante papel, transformando o imaginário de todos nós, abrindo perspectivas para a interpretação do presente, releitura do passado, projeção e criação do futuro, que fazem parte das representações que evidenciam a consciência musical e histórica dos alunos.

Em termos de consumo e utilização das músicas, também sofreram enorme impacto com o acesso às novas tecnologias, particularmente pela velocidade com que as novas ferramentas transformaram em técnica o contato com as canções. De tal modo que hoje é impossível imaginar o universo musical, sem a internet, computadores, softwares para fazer downloads de músicas, ipods ou celulares, pois a maioria dos alunos entrevistados escuta as músicas dentro e fora da escola utilizando-se dessas tecnologias. 
Como os alunos escutam músicas (apêndice III - tabela 7).

\begin{tabular}{|c|c|}
\hline Aparelho portátil - walkman (fita cassete, cd player, ipod ou celular) & $75 \%$ \\
\hline Aparelho de som (fita cassete, $c d$, vinil ou mp3) & $53 \%$ \\
\hline Computador & $69 \%$ \\
\hline Rádio - Rádio do carro & $62 \%$ \\
\hline Televisão (vídeo ou $d v d$ ) & $50 \%$ \\
\hline Não especificou & $3 \%$ \\
\hline
\end{tabular}

Como os alunos escutam música na escola (apêndice III - tabela 9)

\begin{tabular}{|c|c|}
\hline Aparelho portátil - walkman (fita cassete, $c d$ player, ipod ou celular) & $53 \%$ \\
\hline Aparelho de som (fita cassete, $c d$, vinil ou mp3) & $94 \%$ \\
\hline Computador & $28 \%$ \\
\hline Rádio & $6 \%$ \\
\hline Televisão (vídeo ou $d v d$ ) & $6 \%$ \\
\hline
\end{tabular}

A maioria dos alunos entrevistados, mesmo que não seja de forma exclusiva, utilizamse de uma tecnologia (aparelho portátil ou computador), dentro e fora da escola, o que estimula a individualização da escuta. Esse processo pode se transformar em um obstáculo para a introdução de qualquer prática de audição coletiva se o professor não estiver atento em relação a essa questão, pois pode dificultar a mediação entre alunos e o professor, o que não ocorre com a professora Marli, que tem consciência desse processo, procurando minimizar os efeitos da individualização por meio da valorização da rádio da escola, permitindo que os alunos trouxessem as músicas para a sala de aula, tornado a audição coletiva uma prática mais habitua. Isso se evidencia quando os alunos citam os aparelhos de som da escola como uma forma de escuta dentro e fora da sala de aula.

No contexto familiar, apesar da escuta individualizada, a mediação através da música se dá essencialmente de forma afetiva. Nesses processos de mediação cultural, os jovens encontram e participam de relações cuja ligação afetiva (sentimentos e emoções) interligavase também com a dimensão sonoro-musical do canto e da dança. $\mathrm{O}$ processo de constituir-se enquanto sujeito - que se iniciava -, estava permeado pela música, própria da família e da comunidade onde estão inseridos, em momentos específicos de tempo e espaço.

Desse modo, a música tornou-se parte integral da sua cultura. Nesse processo inicial de aprendizagem da cultura musical, os jovens, pela mediação de outros significados, começaram a formar uma bagagem com vivências musicais junto do ambiente familiar. Apropriaram-se delas como constitutivas de sua subjetividade. Aprenderam, segundo WAZLAWICK, 2006:5), a cultivar a música como algo importante, porque era uma realidade emocional vivida no grupo familiar onde se encontravam . 


\section{Contato com os estilos musicais e artistas preferidos (apêndice III - tabela 6)}

\begin{tabular}{|c|c|}
\hline Cinema & $3 \%$ \\
\hline Colegas & $37 \%$ \\
\hline Escola & $31 \%$ \\
\hline Família & $41 \%$ \\
\hline Internet & $50 \%$ \\
\hline Rádio & $62 \%$ \\
\hline Televisão & $50 \%$ \\
\hline Vídeo - DVD & $31 \%$ \\
\hline
\end{tabular}

Como os alunos tiveram contato anterior com as músicas e artistas apresentados pela professora durante o curso (apêndice III - tabela 13)

\begin{tabular}{|c|c|}
\hline Família & $23 \%$ \\
\hline Rádio do carro & $23 \%$ \\
\hline Não especificou & $54 \%$ \\
\hline
\end{tabular}

Apesar da escuta dos alunos tornar-se cada vez mais individualizada, ainda se nota a importância das famílias em relação ao contato inicial com os artistas e estilos musicais preferidos. É importante salientar como esses alunos tiveram contato anterior com as músicas e artistas apresentados pela professora durante o curso.

Posteriormente, a relação com esse estilo musical se modifica, assim como as emoções a respeito dessa vivência. Outra multiplicidade de sentidos, ao longo do tempo, leva à construção de novos significados que farão os alunos visualizarem crescimentos, transformações enquanto pessoas e nas suas relações com a música, quando a escola passa a ter um importante papel nesse processo. Apesar de um visível afastamento da construção e do significado em relação à música apreendida no contexto familiar, ela ainda é referência, pois faz parte de um momento histórico que se transforma enquanto eles se transformam quanto pessoas, o que possibilita uma mudança de significação para a música.

Na infância, a música se faz presente em brincadeiras, jogos, apresentações, dança, canto, ou seja, no inventar do imaginário infantil. O que podemos imaginar é que o próprio som fascina a criança em primeiro lugar. Segundo RUDD (1991:170), há experiências ricas, emocionais, e às vezes máximas, que a análise formal da música não permite capturar . $\mathrm{O}$ sentir é parte inerente da atividade musical, integrando pensamento, imaginação e afetividade. A percepção da forma pela qual a música revela sentimentos e emoções se transforma em referência da memória de cada um desde os primeiros anos de vida.

A partir da entrada na adolescência, faixa etária analisada nesta pesquisa (apêndice III - tabela 1), o jovem começa a apresentar uma oscilação entre dois núcleos de significado: o 
que os outros (família e amigos) cultivavam na música e o que ele quer e considera que seria a sua identidade própria na música, algo que passa a ser mediado pelos meios de comunicação e a cultura escolar. Trata-se de uma vivência contraditória e dialética com esses núcleos de significado em meio à constituição da sua identidade através da música, que também se encontra relacionada à forma como esse jovem ouve as músicas.

Essa questão afetiva em relação à linguagem musical também se torna evidente no caso da professora Marli, quando ela fala das influências musicais na infância, na adolescência e na escola básica.

Influência musical na infância e adolescência (apêndice VIII - quadro 11)

\begin{tabular}{|c|}
\hline Cresceu ouvindo o rádio e cantando o repertório da jovem guarda \\
\hline O pai ouvia Adoniran Barbosa interpretado pelos Demônios da Garoa (trabalhou em sala de aula) \\
\hline A mãe ouvia Nelson Gonçalves \\
\hline $\begin{array}{c}\text { Na casa da avó materna havia uma vitrola que propiciava a transformação dos encontros familiares em } \\
\text { bailes (Luiz Gonzaga, Clara Nunes e Martinho da Vila - já trabalhou uma canção deste último em sala } \\
\text { de aula) }\end{array}$ \\
\hline Programa de rádio “Barros de Alencar" ( "música brega ") \\
\hline Nos anos 70: Raul Seixas, Rita Lee e Secos \& Molhados (maior influência da televisão) \\
\hline Rádio Difusora AM (final dos anos 70) e Radio Cidade FM (início dos anos 80) \\
\hline
\end{tabular}

Influência musical na escola (apêndice VIII - quadro 12)

\begin{tabular}{|c|}
\hline Músicas cantadas em datas comemorativas (anos 70) \\
\hline Aulas de Inglês: The Platers, Elvis Presley e Frank Sinatra \\
\hline Letras utilizadas nas aulas de Português sem a música (ginásio e colegial) \\
\hline
\end{tabular}

A afetividade da professora em relação à música também é ressaltada no relato da sua experiência no livro "Cantando a História":

"Lembro-me bem de que em meados dos anos de 1960, ainda na idade pré-escolar, encantei-me com as músicas da Jovem Guarda que então eu ouvia no rádio de minha casa $\boldsymbol{e}$ cantava pelos quatro cantos para alegria de meus familiares.

Já na escola primária, evidenciou-se meu gosto pelas canções ensinadas pelas minhas professoras, que, além de ensinar valores conceitos e conteúdos, me proporcionavam uma enorme alegria em cantá-las em altos brados pelos pátios das escolas onde estudei. 
Dentre os muitos mestres que tive na trajetória da vida escolar, destaco aqui a presença da professora Valdirene Aparecida Xavier Barroquello, que me ensinou 'O Inglês com música', em suas aulas inesqueciveis, nos idos dos anos de 1970, na 'E.E. Dom Pedro I' localizada em São Miguel Paulista, bairro da zona leste de São Paulo.

Na adolescência, tive vários momentos marcados elo som das músicas da época.

Por meio das canções experienciei um mundo de sentimentos, pensamentos e sonhos descortinar-se diante de meus olhos.

Assim foi o início de tudo..." (CARVALHO, Marli Oliveira de. Cantando a História:um método dialógico de construção dos saberes históricos na escola. São Paulo: Ed. Do Autor, 2008. P. 12.)

Essa memória afetiva em relação à linguagem musical influencia não só nas preferências de ritmos e músicas da professora como adulto (apêndice VIII - quadro 4), como também lhe influencia a prática pedagógica quando, por exemplo, cita Adoniran Barbosa e Martinho da Vila (apêndice VIII - quadro 11), como autores de canções com as quais trabalhou em sala de aula e fazem parte da sua infância e adolescência no âmbito familiar.

Já no âmbito escolar, a professora lembra as letras das canções nas aulas de Inglês e Português (apêndice VIII - quadro 12), transformando a prática pedagógica das suas antigas professoras em uma referência do seu trabalho em sala, principalmente quando a professora Marli fala da construção da sua aula utilizando a linguagem musical e a relação da mesma com o conteúdo.

A construção da aula utilizando a linguagem musical (apêndice VIII - quadro 16)

- "Procuro e trabalho canções que se relacionam com o conteúdo".

A relação entre música e conteúdo (apêndice VIII - quadro 17)

- "Aula expositiva explorando o vocabulário da letra da canção".

- "Releitura da letra identificando determinados versos e relacionando-os ao conteúdo". 


\section{A função emocional da música no cotidiano e o ouvir música na escola}

Há muitas, quase infinitas maneiras de ouvir música. Entretanto, pelo menos três delas poderiam ser chamadas de dominante, segundo MORAES (2000): ouvir com o corpo, ouvir emotivamente e ouvir intelectualmente.

A primeira delas, o ouvir com o corpo, é empregar no ato de escuta não apenas os ouvidos, mas a pele toda, que também vibra ao contato com o dado sonoro: é sentir em estado bruto, misturar o pulsar do som com as batidas do coração, é um quase não pensar e viver o estimulo sonoro de forma instintiva. Nesse estágio, não há necessidade da presença de palavras, como mediadora, para falar da relação indivíduo-música.

A segunda maneira de ouvir música se dá em outro plano: sai-se da sensação bruta e entra-se no campo dos sentimentos, da emotividade. Quando uma pessoa confessa que, chorou ao ouvir uma canção - é sinal que ela está no domínio do ouvir emotivo. Nesta segunda forma de audição sobram os adjetivos para definir e retratar os efeitos de uma determinada canção: "linda", "triste", "maravilhosa", "música de enterro"... Ouvir emotivamente, no fundo, não deixa de ser ouvir mais a si mesmo do que propriamente a música. Nesse caso, utilizamos a música a fim de que ela desperte ou reforce algo já latente em nós mesmos.

Já ouvir música intelectualmente é dar-se conta de que ela tem, como base, estrutura e forma. Estrutura seria a maneira de organizar os elementos tendo em vista o conjunto geral dessa ordenação; forma seria exatamente esse aspecto geral - soma de estruturações particulares, locais - tomado em si mesmo. Referir-se à música a partir dessa perspectiva seria atentar para a materialidade da linguagem musical; o que ela comporta, como os elementos se estruturam, qual a forma alcançada nesse processo. Desvendar o funcionamento da linguagem musical, assim, pode provocar um tipo muito especial de emoção, talvez a chamada emoção estética, que quase não tem mais nada a ver, conforme MORAES, (1983:63) com aquela outra emoção que fazia o ouvinte chorar diante de uma canção.

De acordo com essa classificação, podemos afirmar que, nas esferas do cotidiano familiar, do lazer e da escola a segunda forma é preponderante, pois ouvir música emotivamente é ouvir mais a si mesmo do que a própria música. É se utilizar da música para que ela desperte ou reforce algo já latente em nós mesmos em busca de uma identidade com o outro. 
“(...) O adolescente que se tranca em seu quarto, ouve sua música alta, balança a cabeça para frente e para trás acompanhando a batida dos tempos está assertivamente declarando seu gosto. Mais: está dizendo que pertence a um grupo ideal que compartilha daquele gosto (e da forma de vestir-se e de falar) e que nisto ele se distingue daqueles que ocupam o território mais além da porta do quarto. A música em sua maior ou menor elaboração está ali configurando, por assim dizer, um som específico, um gênero. Do mesmo modo como os tambores de guerra, a sirene da polícia, o sino da igreja, em suas configurações, reclamam territórios e poder, a música do adolescente também o faz.” (DOTTORI, 2006: 146).

A função emocional da música é realçada por estudiosos da psicologia, quando afirmam que a razão pela qual a maioria de nós participa em atividades musicais, sejam elas, ouvir, cantar, tocar ou dirigir, é que a música tem a capacidade de suscitar emoções profundas e significativas. Se os fatores emocionais são fundamentais para a existência da música, a questão principal para a investigação psicológica em música é o modo como a música é capaz de influenciar as pessoas. $\mathrm{O}$ que, no caso desta pesquisa, se transforma em como os jovens adquirem consciência musical e de como ela auxilia na formação da consciência histórica dos alunos.

A música é acessível à maioria das crianças e dos jovens, em contextos variados, e ouvir música é uma das suas principais atividades de lazer, pelo menos nas sociedades ocidentais. Ouvem música em lugares públicos e por meio da mídia, sozinhos ou em companhia da família e dos amigos. Segundo PALHEIROS, (2006: 305) (apêndice III tabelas 6 e 7), cantam em coros, tocam em grupos nas comunidades locais e frequentam aulas de instrumento. Criam a própria música em grupos de amigos, imitam os cantores preferidos e discutem música com os seus pares. Embora muitos jovens não participem da interpretação ou produção musical, em situações informais ou formais, a grande maioria deles ouve música regularmente: por vezes, ao vivo, mas, sobretudo, música gravada.

Apesar das múltiplas funções da música na vida dos jovens, ocorre em diversos contextos. As diferentes maneiras de ouvir e utilizar a música podem estar relacionadas com as funções dela e podem depender de características pessoais do ouvinte (idade e formação musical), da situação (intenção de ouvir, atenção) e do contexto (físico, social, cultural, educativo). Portanto, somos obrigados a considerar as diferenças entre a casa (fora da escola) e a escola (aulas de música e com músicas) como contextos em que as crianças ouvem música habitualmente. Em casa, as crianças geralmente decidem por que, quando, quantas vezes e durante quanto tempo ouvem música. Também escolhem onde, como e com quem ouvem 
(habitualmente, família e amigos); selecionam estilos, intérpretes e peças preferidos. Embora algumas situações informais de ouvir música sejam condicionadas por fatores que escapam ao controle dos jovens (por exemplo, música de fundo em lugares públicos), na maioria dos casos, ouvir música depende dos próprios ouvintes.

Na escola, pelo contrário, a audição musical é apresentada, na maioria das vezes, como uma atividade formal com frequência, duração, objetivos e conteúdos pré-determinados, como no caso da escola. Os jovens ouvem música com os colegas de turma, que não escolheram, e o professor, na maioria das vezes, define que estilos e canções são incluídos na programação. Essas diferenças contextuais implicam que os jovens poderão desenvolver diferentes atitudes relativamente à audição em cada contexto: ouvir música em casa pode ser uma atividade mais significativa, porque possui funções que são mais valorizadas pelos alunos do que as funções de ouvir música na escola.

Enquanto estilo de ouvir música implica características mais estáveis dos ouvintes quanto ao seu gosto, o modo de ouvir música sugere mudança de situações, pois um ouvinte pode experimentar diferentes modos de ouvir música. São aqui propostos quatro modos de ouvir música, mental e fisicamente passivos ou ativos, implicando diversos graus de envolvimento. Os jovens podem usar diferentes modos, em diferentes contextos (ouvir sentadas nas aulas; ouvir e cantar, em casa, sozinhas ou com amigos) ou durante a mesma música, dependendo da sua atenção e da sua intenção de ouvir. Essa visão dinâmica pressupõe que os modos variam conforme o contexto, a música e as expectativas do ouvinte, formando um habitus musical, o que sugere uma disposição para ouvir com um determinado tipo de enfoque, esperando experimentar certas emoções.

Alguns autores, ligados à psicologia, entre eles PALHEIROS (2006: 324-325) estabelecem quatro modos de ouvir música que seriam os seguintes: como "música de fundo"; como acompanhamento de atividades, como atividade principal ou como audição e interpretação das músicas. O primeiro modo, ou seja, ouvir "música de fundo", ocorre quando as pessoas fazem outras atividades, sem que prestem a atenção a elas. A música é ouvida, mas não ativa nem intencionalmente. Geralmente, os jovens não estão conscientes da música: não pretendem ouvi-la e nem prestam atenção.

Ouvir como acompanhamento de atividades faz com que as funções da música variem conforme os ouvintes e a natureza da tarefa. Os jovens selecionam música, para acompanhar atividades extramusicais, entre elas, ler e jogar no computador. Podem prestar atenção à música, mas geralmente estão concentrados nessas atividades. Verificou-se que a música é usada mais como atividade secundária pelos adolescentes que não estão envolvidos 
diretamente com ela.

Ouvir como atividade principal implica em os jovens ouvirem música intencionalmente. Embora possam usar a música para relaxar e possam variar o seu grau de atenção, em geral concentram-se mentalmente na música. Ouvem com a atenção focada e o envolvimento emocional pode ter funções emocionais e cognitivas, como o prazer estético, que será o principal foco de análise nesta pesquisa quando envolve as aulas de História.

Os jovens ouvem atentamente a música e respondem fisicamente quando se trata de ouvir e interpretar: cantar e dançar uma canção implica conhecer bem os seus elementos. Essa interpretação, individual ou em grupo, pode ser uma expressão de prazer, uma maneira de as crianças aumentarem a participação na música, ou ainda um modo de exprimirem identificação com os cantores preferidos, ou com os seus pares.

Dessa forma, os quatro níveis de audição são importantes para o entendimento dessa atividade dos jovens, pois interferem no envolvimento emocional, na cognição e no prazer estético. Como veremos a seguir, encontram-se em maior o menor grau nas atividades musicais da escola pesquisada.

\section{O gosto e a consciência musical}

Identificar esses quatro níveis de audição revela outro aspecto importante da pesquisa sobre as relações entre ouvir música em casa e na escola e que podem ser bastante influenciadas pela idade do aluno. As teorias psicológicas tentam explicar as transformações desenvolvimentais que ocorrem entre a infância tardia e a adolescência precoce, realçando a importância relativa das relações com a família e com o grupo de pares no processo de socialização e formação da identidade. Um conjunto crescente de resultados de investigação tem evidenciado o papel da audição musical no desenvolvimento da identidade pessoal e social, na formação de relações interpessoais e na regulação do humor e da emoção.

As investigações também têm se debruçado sobre as mudanças no significado de ouvir música, ocorridas com a idade, procurando investigar como e por que os jovens ouvem música e identificando nove estilos de audição em participantes entre os 11 e os 20 anos de idade, relacionados com componentes emocionais, cognitivas e físicas. Os autores, entre eles PALHEIROS (2006: 310), verificam desenvolvimentos significativos na audição e apreciação de música na adolescência tardia: a frequência dos estilos de audição aumentava, e alguns estilos mudavam com a idade. Há diferenças identificáveis no grau de tolerância dos estilos preferidos. A literatura sugere que a "abertura de ouvido", ou seja, a tolerância relativamente a 
uma série de estilos diferentes aumenta na infância, diminui no início da adolescência (universo dos alunos observados nesta pesquisa), que volta a aumentar na adolescência tardia, e diminui mais uma vez na idade adulta.

A utilização da linguagem musical no interior da escola ainda é muita restrita no Brasil, apesar de os Parâmetros Curriculares Nacionais falarem da importância da linguagem musical $^{9}$, e o governo brasileiro tornar o ensino de música obrigatório a partir de $2008^{10}$, é natural, que o contato, a assimilação e a aprendizagem da linguagem musical da maioria dos alunos ocorra fora da escola, sendo que a maior parte (76\%) não exerce qualquer atividade relacionada à prática musical (anexo I - tabela 8).

Portanto, fora da escola, a atividade musical está relacionada ao ato de ouvir música de forma emocional e sem envolver a dimensão técnica e intelectual da linguagem musical. O que tornaria natural a utilização da música por professores e alunos de uma forma afetiva na escola, sem necessariamente apresentarem conhecimentos técnicos prévios em relação à música. Isso também evidencia por que ritmo e letra chamaram a atenção indistintamente dos alunos (94\%) durante as aulas de História, apesar de a professora destacar a letra, o apelo emocional ditado pelo ritmo das canções acabou recebendo a mesma atenção dos alunos durante as execuções das músicas (anexo I - tabela 15).

A nova estética experimental proposta por BERLYNE (1970) sugere que as propriedades dos estímulos artísticos, como a complexidade e a familiaridade, produzem prazer a partir da manipulação do nível de excitação do observador. As pessoas geralmente preferem estímulos que produzam um nível intermediário de excitação. No caso da música, elas gostam das que sejam moderadamente familiares e que tenham complexidade média. Vários estudos sobre as preferências musicais do dia-a-dia parecem confirmar essa teoria. NORTH \& HARGREAVES (apud PARELHEIROS, 2006:330) sugerem ainda outro fator importante na determinação das preferências musicais: a adequação da música a uma determinada situação de audição .

\footnotetext{
9 “Aprender a sentir, expressar e pensar a realidade sonora ao redor do ser humano, que constantemente se modifica nessa rede em que se encontra, auxilia o jovem e o adulto em fase de escolarização básica a desenvolver capacidades, habilidades e competências em música. Construindo sua competência artística nessa linguagem, sabendo comunicar-se e expressar-se musicalmente, o aluno poderá, ao conectar o imaginário e a fantasia ao processo de criação, interpretação e fruição, desenvolver o poético, a dimensão sensível que a música traz ao ser humano" (Parâmetros Curriculares Nacionais - Arte: 80).

${ }^{10}$ Lei $\mathrm{N}^{\mathrm{o}} 11.769$, de 18 de agosto de 2008, que altera a Lei $\mathrm{n}^{\mathrm{o}}$ 9.394, de 20 de dezembro de 1996, Lei de Diretrizes e Bases da Educação, para dispor sobre a obrigatoriedade do ensino da música na educação básica.
} 
Nesse caso, os gostos ligados aos gêneros musicais (anexo I - tabela 3) além de suscitarem, em primeiro lugar, uma busca de identidade por parte dos jovens entrevistados, também se encontram profundamente ligados a algum uso ou função social de uma parcela da sociedade em um dado momento de sua história. Em segundo lugar, é na escolha de algum dentre os gêneros possíveis que se funda e se exerce o gosto. Terceiro, se o gosto é político, pode certamente ser discutido. Como, por exemplo, estabelecer ligações entre os ritmos negros black e rap com os temas violência, racismo e injustiça social sem a interferência da professora (anexo I - tabela 16). A recusa dos alunos em fazê-la (48\% dos entrevistados) já é uma tomada de posição política, trata-se de uma demarcação do território. O gosto pode ser limitação; percebê-lo é o primeiro passo para aprender a compor com as demais pessoas ${ }^{11}$.

As preferências musicais podem ser influenciadas por uma diversidade de fatores inter-relacionados: características da música, corno elementos musicais, estilo e interpretação (instrumentos, intérpretes), complexidade e familiaridade (repetição), caráter emocional (emoções da música e estados emocionais que a música pode suscitar); características pessoais, cor, idade, sexo, nacionalidade, estatuto socioeconômico, personalidade, formação musical; e fatores extramusicais, como o contexto social (situação de audição), agentes de socialização (família, amigos, professores, e a mídia), efeitos de grupo (por exemplo, conformidade e prestígio), e aculturação (meio musical). Portanto, nesse caso, o gosto musical transforma-se em uma representação afetiva da mediação elaborada pelo aluno em relação ao mundo que o cerca, e que, devido ao seu caráter eminentemente afetivo transforma-se em memória pessoal e modelo de referência para a apreensão e assimilação das novas audições dos jovens, similares ou não as anteriores, revelando assim o que podemos chamar de consciência musical.

\section{A música como a arte suprema da representação humana}

Segundo SCHOPENHAUER (1974:23; 78-9), quando instituída, a obra de arte é uma espécie de empréstimo que o artista nos faz de seus olhos. Assim, por meio de uma pintura, estátua, poesia, edifício, jardim e principalmente a música, temos acesso à sua visão e, igualmente, à essência do mundo. A arte é a exposição de representações independentes do princípio de razão; já a realidade é a exposição de representações submetidas ao princípio de

\footnotetext{
11“'O gosto, o bom gosto, é basicamente uma categoria aristocrática: nós o temos, pois 'é o sentimento interior mais natural, corrigido ou confirmado pelas regras' (La Viéville, 1704); para um autor dos seiscentos como La Viéville, os outros, menos bem nascidos, por mais que se esforcem, nunca o adquirem" (DOTTORI, 2006: 147).
} 
razão. Na pirâmide hierárquica estabelecida pelo autor, a música, magnânima, está acima das demais artes. Não expõe apenas uma ideia ou leva à abstração de algumas imagens, que identificarei adiante de "paisagens sonoras". É especialíssima: fala diretamente a linguagem da coisa-em-si. A arte dos sons não reproduz uma intuição estética; é a mensagem direta e imediata do âmago das coisas. A música é a mais grandiosa, a mais majestosa das artes, é uma rainha poderosíssima. Por intermédio de sua linguagem, entendida claramente em qualquer canto do planeta, atinge o mais abismal de nossa subjetividade. Os sons não precisam de tradução, são compreendidos certeira e imediatamente. Quando as emoções são despertas pela arte dos sons, esta é sentida à flor da pele. Essas emoções não afirmam a vontade; ao contrário, na audição musical há completa negação do querer; o experimentado em tais ocasiões é puro, abstrato, espiritual, sem o nervo sensitivo. A música não expressa esta ou aquela alegria, esta ou aquela aflição, este ou aquele sofrimento, mas as emoções mesmas, o fundamental, o inalterável delas. Se nas outras formas de exposição artística encontramos a ideia exposta, na música, diferentemente, encontramos, sem intermediações, a mensagem direta da coisa-em-si . A fantasia se encarrega de sonhar durante a audição musical; interpreta os sons, a melodia, a harmonia, o ritmo e nos transporta para mundos perfeitos, para regiões encantadoras. Figuramos o invisível, o espiritual, e construímos um mundo irretocável e “paisagens sonoras”. Há, assim, um paralelo entre música e ideia.

O papel de arte suprema e majestosa conferido pelo autor à arte musical é reforçado quando o filósofo chama a atenção para o fato de cenas, ações, acontecimentos serem extremamente vivificados quando, ao fundo, toca uma música apropriada, esclarecedora do conteúdo do evento, comentário verdadeiro do acontecido, como nas cenas de filmes e novelas, dependendo da emoção a ser transmitida, mas principalmente acaba fazendo parte dos momentos significativos de cada pessoa. Para SCHOPENHAUER (1974), a linguagem musical corresponde à essência da verdade, pois a música fala a linguagem direta e imediata da vontade (intuição imediata cognoscível), pois, ao ouvirmos uma agradável composição, o mistério das coisas é revelado.

Para o filósofo, poderia não haver fenômenos, aparências, representações submetidas ao princípio de razão, mas haveria o íntimo cósmico, independente do referido princípio, a vontade $^{12}$, cuja música expressaria o seu âmago e a sua representação estaria no gosto musical

\footnotetext{
12 “(...). Esta vontade é em si, i. e., fora da representação, cuja forma é sempre pelo menos sujeito e objeto, nos separamos como indivíduo conhecido e conhecedor. Suprimido o conhecedor, o mundo como representação, nada resta além de simples vontade, ímpeto cego. (...)”(SCHOPENHAUER, 1974: 20).
} 
de cada um de nós.

A representação, ainda segundo SCHOPENHAUER (1974), pressupõe o envolvimento simultâneo das noções de sujeito e objeto, o que significa dizer que, ao se pensar no sujeito, logo se nota que tal noção envolve também a de objeto. E vice-versa, quando se pensa no objeto, automaticamente já temos de pensar no sujeito. Não é possível pensar em um sem ao mesmo tempo pensar no outro: ambos os conceitos estão ligados analiticamente, vale dizer, basta analisar um isoladamente para se encontrar o outro contido nele. Estamos diante de um amálgama teórico que nenhum corte, nenhum raciocínio lógico consegue separar. Onde começa o sujeito termina o objeto; e onde começa o objeto termina o sujeito. Ser-objeto significa ser conhecido por um sujeito. Ser-sujeito significa ter um objeto, que no caso da relação entre música e sujeito se dá, principalmente, através da memória.

Para o filósofo, a representação é uma complexa atividade fisiológica no cérebro de um animal ao fim da qual se tem a consciência de uma imagem. Portanto, a representação do mundo material, exterior, é tudo aquilo que aparece como figura para o entendimento, ou seja, algo colocado diante de nós que pode ser objeto, fenômeno, intuição, aparência.

A representação nela mesma não revela a sua essência íntima, o seu núcleo, daí poder-se dizer que é ilusória, enganosa. Em termos estritamente empíricos, é pelos sentidos que os primeiros dados fornecidos pela experiência conduzem à representação. Porém, antes de termos a posse final da imagem, é necessário previamente todo um elaborado processo mental para construí-la. Em tal processo, o sujeito é ativo, é uma espécie de artesão que possui a priori três formas puras de conhecimento, todas inatas, presentes nele desde o nascimento e que possibilitam a apreensão do mundo circundante. Essas formas são o tempo, o espaço e a causalidade, espécie de "óculos intelectuais" para se conhecer as coisas, vê-las tais quais aparecem, ou seja, de um exato jeito e não de outro e que vão compor a memória do sujeito.

“(...) a música é percebida, ou seja, única e exclusivamente em e mediante o tempo, com inteira exclusão do espaço, sem influência do conhecimento da casualidade, e portanto do entendimento; pois os tons criam a impressão estética como simples efeitos,e sem retorno à sua causa inicial, como no caso da intuição.”(SCHOPENHAUER,1974: 87).

Esse empirismo temporal do sujeito, estimulado pela linguagem musical será de fundamental importância na construção da consciência temporal do homem finito, da qual faz parte a consciência musical e histórica. Nesse caso, a música estimula representações comuns 
fundamentadas no conhecimento, que são mais fluidas, pragmáticas, passíveis de teste de acerto ou erro, o que deixa certa liberdade para a linguagem, a experiência e até mesmo para as faculdades críticas dos indivíduos (MOSCOVICI, 2005: 189).

As representações sociais, no caso desta pesquisa, devem ser vistas como uma maneira específica de compreender e comunicar o que nós já sabemos. Ocupam, com efeito, uma posição curiosa, em algum ponto entre conceitos, que têm como seu objetivo abstrair sentido do mundo e introduzir nele ordem e percepções, que reproduzam o mundo de uma forma significativa (MOSCOVICI, 2005: 46), principalmente através da linguagem musical.

\section{Memória, consciência musical e conhecimento histórico}

Como destaquei, retomando algumas ideias de SCHOPENHAUER (1974), as representações estimuladas pela linguagem musical são construídas através de uma memória que se utiliza essencialmente do tempo e é revelada, em grande, parte pelo gosto musical de cada um de nós. Portanto, fica a indagação de como seria essa memória musical.

Trata-se de uma memória composta basicamente por dois elementos interdependentes: a identificação e a afetividade. A memória de identificação seria a capacidade que temos, na maioria dos casos, de identificar músicas que ouvimos antes, processo semelhante à memória que temos de rostos, fotografias, sabores e cheiros, com um certo grau de variação individual, mostrando-nos que certas pessoas possuem um grau de maior facilidade de identificação sonora do que outras (LEVITINI, 2010: 246), mas todas, ao escutarem uma canção, estabelecem padrões de identificação a partir de experiências anteriores que são balizadas pela afetividade que, por sua vez, faz parte da memória do sujeito.

A memória musical existe, e como os outros tipos de memória encontram-se enraizadas em diferentes contextos. A rememoração pessoal de uma música estabelece uma sincronia com a existência social atual de cada pessoa emergindo aquela forma que chamamos de lembrança. A lembrança é a intersecção de muitas correntes do "pensamento coletivo". É por isso que, segundo HALBWACHS, 2006: 14-15), sentimos dificuldade para lembrar acontecimentos que só dizem respeito a nós mesmos, sem termos uma referência de contexto social, algo que se torna mais fácil se tais fatos estiverem ligados a uma determinada música que nos faz relembrar o contexto e as emoções do passado.

A nossa memória individual se aproveita da memória dos outros, pois precisa concordar em alguns pontos com as memórias dos que convivem conosco para que a 
lembrança que nos faz recordar venha a ser reconstruída sobre uma base comum.Para HALBWACHS (2006: 51), é preciso que essa reconstrução funcione a partir de dados ou de noções comuns de passado, que tenha um mesmo referencial de tempo para as pessoas de uma mesma sociedade, ou um pequeno grupo social, como no caso dos alunos e da professora desta pesquisa. Somente assim podemos compreender que uma lembrança seja ao mesmo tempo reconhecida e reconstruída, transformando-se assim em memória.

Na memória de um grupo, destacam-se as lembranças dos eventos e das experiências que dizem respeito à maioria de seus membros e que resultam de sua própria vida ou de suas relações com os grupos mais próximos, os que estiverem mais frequentemente em contato com eles. Dessa forma, para que a memória dos outros venha assim reforçar e completar a nossa é preciso que as lembranças desses grupos não deixem de ter alguma relação com os acontecimentos que constituem o passado de cada indivíduo, conforme HALBWACHS (2006:98). Isso fica evidenciado na pesquisa, porque os alunos e a professora trabalham a sua memória afetiva em função das influências musicais na família e na escola, pois a linguagem musical é um forte elo entre a memória do grupo de origem e a memória individual dos entrevistados.

HALBWACHS (2006) não estuda a memória como tal, mas os quadros sociais da memória. Portanto, lembrar não é reviver, mas refazer, reconstruir, repensar, com imagens e idéias de hoje, as experiências do passado. A lembrança fixada pela memória é uma imagem construída pelos elementos que estão à nossa disposição, no conjunto de representações que povoam nossa consciência no presente. A construção dessas imagens, quando estimulada tanto pela afetividade como pelas "paisagens sonoras" da linguagem musical, forma uma memória musical que se transforma em uma consciência musical.

Essa consciência individual é formada por imagens, sentimentos e pensamentos que resultam dos diversos ambientes sociais de que fizemos e fazemos parte em nossa vida e que são marcados significativamente por uma determinada trilha sonora que compõem a história de cada um e que vai balizar o nosso gosto e a nossa audição até o final de nossas vidas. Assim, a consciência musical tem uma função prática que confere à realidade uma direção temporal, uma orientação que pode guiar intencionalmente a ação através da mediação da linguagem musical auxiliando na construção da memória histórica.

Essa orientação temporal é formada, segundo RÜSEN (1992:29), por duas esferas: a vida prática (aspecto externo ao indivíduo), temporalidade marcada pela atividade humana; e a subjetividade interna dos atores, dimensão temporal da subjetividade humana. Algo que toma uma forma mais concreta através da identidade histórica, em que a personalidade humana expande a 
extensão temporal além dos limites da própria existência criando, assim, uma consciência histórica que pode ser exemplificada pelas representações dos estudantes e da professora em relação às músicas executadas na escola. As representações construídas pelos alunos evidenciam a forma linguística dentro da qual a consciência histórica realiza sua função de orientação, que é a narração. A narrativa constitui especificamente a consciência histórica na medida em que recorre às lembranças para interpretar as experiências do tempo. A lembrança é, para a constituição da consciência histórica, por conseguinte, a relação determinante com a experiência do tempo.

Esse tipo de relação com a experiência é o que está, afinal, na base da distinção entre a narrativa historiográfica e a ficcional. Esse recurso à lembrança deve ser pensado de forma que se trate sempre da experiência do tempo, cuja realidade atual deve ser controlada pela ação, mas que também admita ser interpretada mediante mobilização da lembrança de experiências de mudanças temporais passadas dos alunos e da professora através da linguagem musical. O passado é, então, conforme RÜSEN (2000:62), como uma floresta para dentro da qual os entrevistados, pela narrativa histórica, lançam suas indagações, a fim de compreenderem, mediante o que dela ecoa, o que lhes é presente sob a forma de experiência do tempo (mais precisamente: o que mexe com eles) e poderem esperar e projetar um futuro com sentido (Rüsen, 2001: 62). Algo estimulado pela linguagem musical, pois a música é percebida, segundo SCHOPENHAUER (1974:87), ou seja, única e exclusivamente em e mediante o tempo. Com isso, o passado passa a ser articulado, de forma mais natural, como estado de coisas, com as orientações presentes no agir contemporâneos dos entrevistados, assim como as determinações de sentido em relação aos conteúdos desenvolvidos em sala de aula.

As representações históricas dos alunos e da professora estimuladas pela linguagem musical têm de ser pensadas como algo que emerge de determinados processos da vida humana prática. A questão que se põe nos processos de constituição de sentido pela consciência histórica não diz respeito, sobretudo ou exclusivamente ao passado, mas à interdependência entre passado, presente e futuro, pois só nessa interdependência os homens conseguem orientar sua vida, seus atos, no tempo. Como representação de ação que se estende pelo passado, presente e futuro, a própria história faz parte dos atos, pois os atos da vida prática desses jovens pressupõem um mínimo de orientação no tempo, como ficou evidenciado pelas representações elaboradas pelos alunos. Trata-se aqui de uma eficácia do passado no presente que não se refere à orientação intencional da vida prática atual. $\mathrm{O}$ passado é eficaz, por conseguinte, como conjunto silencioso do agir, seja de modo implícito e natural, como, por exemplo, na "vida institucional" (escola), seja nos bastidores dos processos decisórios da "vida cotidiana" (influenciados por colegas, família e meios de comunicação). 


\section{CAPÍTULO 3- A MEDIAÇÃO CULTURAL E A "PAISAGEM SONORA" DA SALA DE AULA}

As representações históricas dos alunos e da professora estimuladas pela linguagem musical têm de ser pensadas como algo que emerge de determinados processos da vida humana, entre os quais, a prática do ensino de História em sala de aula, levando em consideração determinados aspectos da música como fenômeno de mediação cultural e suas relações com a linguagem pictórica e escrita.

Já no primeiro dia de observação, a professora fez questão, junto com a sala, de exemplificar como havia trabalhado com os alunos desde o início do ano retomando o conteúdo ministrado (pré-história brasileira e civilizações hidráulicas: Egito e Mesopotâmia), cantando respectivamente com os alunos as músicas "Curumim chama cunhatã que eu vou cantar (todo dia era dia de índio)" (Jorge Ben Jor e Tim Maia) de 1981 e "Planeta água" (Guilherme Arantes) de 1981, momento no qual alunos e professora demonstraram grande empolgação, que também seria demonstrada nas audições posteriores, como aconteceu na sétima aula de observação. Ela teve início com a apresentação da letra e da música "São Paulo, São Paulo” (1982) do grupo Premeditando o Breque ou Premêe, que faria parte da mostra cultural da escola "São Paulo espaço e memória". A professora falou um pouco sobre o grupo que compôs a música e depois leu e explicou a letra da música destacando as palavras que formariam um vocabulário a ser pesquisado pelos alunos até a próxima aula. Enquanto a professora explicava, alguns alunos se manifestavam sobre o fato de conhecerem alguns dos bairros citados pela música.

A canção foi ouvida em três audições: na primeira audição todos apenas ouviram a música; na segunda, todos cantaram ouvindo a música; e na última, todos cantaram com maior ênfase e encerraram a música gritando “yeah!”, depois todos aplaudiram e gritaram. Após a audição, os alunos copiaram a letra da canção para os seus respectivos cadernos.

\section{A música como fenômeno de mediação cultural e criadora de "paisagens sonoras" na sala de aula}

A empolgação dos alunos durante as audições pode ser explicada pela alegria que a música lhes possibilita ao se comunicarem com os colegas e com o professor, através da 
mediação propiciada pela linguagem musical, pois vivem a diversidade, acolhem a diversidade na escuta da música. Segundo SNYDERS (1997:92-93), a linguagem musical é uma via específica que pode abrir uma ampla comunicação entre pessoas diferentes através de uma emoção estética, quer ela seja vivida diretamente como harmonia afetiva das diferenças, quer como convergência, como no caso das audições observadas durante a pesquisa.

Nesses momentos notamos a função da música de aumentar ou diminuir o estado de excitação dos ouvintes, conforme propuseram NORTH \& HARGRAVES, citados em ILARI (2006: 197). Os indivíduos podem escolher gêneros musicais diferentes dependendo do contexto social em que se inserem. Ritmo e andamento musicais parecem ter uma função importante. Em geral, música rápida serve para aumentar o estado de excitação do indivíduo, enquanto música lenta tem uma função de relaxamento ${ }^{13}$. Como já discuti no capítulo anterior, ouvir música emotivamente, no fundo, não deixa de ser ouvir mais a si mesmo do que propriamente a música. É utilizar a linguagem musical para que ela desperte ou reforce algo já latente nos alunos, provocando uma empatia entre eles e a professora.

Outro ponto importante em relação às audições de sala de aula foi o papel da música como fenômeno de mediação cultural da qual imana uma pluralidade de memórias e projetos culturais individuais ou coletivos, pois qualquer que seja nosso comportamento diante da música, de alguma maneira nos apropriamos dela através de um processo de percepção estética de apreciação musical, pois enquanto a música toca, os alunos criam, por um lado, expectativas intrínsecas à forma e ao estilo musical, aprendendo a reagir ao significado musical e criando representações como reação ao evento musical na sala de aula. Por outro lado, a descrição verbal dessas experiências de apreciação musical, que serão destacadas nas entrevistas com os alunos e a professora, deve ser categorizada como reflexão sobre a ação, o que significa transformação da experiência auditiva por meio do uso cognitivo da linguagem discursiva (ÁLVARES, 2006: 442). Apesar de ser crucial para o relato da avaliação da experiência musical, a descrição verbal difere substancialmente da apreciação musical em si, cuja principal referência estará na análise das representações sobre essas experiências no âmbito escolar através das entrevistas com os alunos.

$\mathrm{Na}$ última aula da semana, geralmente às sextas-feiras, a professora sempre levava o aparelho de som portátil da escola para a sala, para que os alunos pudessem ouvir os $c d s$ que

\footnotetext{
13 “A partir desses princípios, é fácil ver como a música gera emoção. A música cria previsões e depois as satisfaz. Ela pode reter suas resoluções, assim aumentando as previsões e, depois, satisfazer as previsões com um grande jorro de resoluções. Quando a música se empenha em violar expectativas que ela própria cria, nós a chamamos de 'expressiva'. Os músicos sopram 'sentimentos' numa peça introduzindo minúsculos desvios no timing e na altura. E os compositores introduzem expressão em suas composições violando intencionalmente as previsões que criaram". (JOURDAIN, 1998: 393).
} 
traziam de suas casas. Na oitava semana, por exemplo, os alunos inicialmente foram reunidos em grupos de até quatro para escolherem gravuras de revistas guardadas na escola que retratassem a música "São Paulo, São Paulo" para, na aula vindoura, confeccionarem cartazes em cartolina e com legendas, que fariam parte da mostra cultural da escola "São Paulo espaço e memória”. Enquanto os alunos escolhiam as gravuras escutariam música, pois seria a última aula daquela semana, já que eles teriam uma avaliação unificada externa aplicada pela Secretaria Municipal de Educação chamada "Prova São Paulo" na sexta-feira (dia de ouvir $c d s$ ).

$\mathrm{O}$ aluno Lucio trouxe um $c d$ com as músicas do grupo de rock Ira que geralmente escuta com o pai, com preferência pela música "Dias de luta” (1986). Após os alunos escutarem mais duas músicas, a professora trocou por um $c d$ da Legião Urbana e colocou a música "Índios" (1986), disco que também foi trazido pelo mesmo aluno, mas foi a canção "Será" (1985) que chamou a atenção dos alunos, cantada por uma parte da classe. Durante a execução das músicas, a professora passava entre os grupos para observar o andamento dos trabalhos, momento em que os alunos mostraram imagens que lhes chamava a atenção e que poderiam ser utilizadas nos cartazes.

Já na última semana de observação (décima primeira semana), havia apenas a presença de quinze alunos na sala, pois se tratava da penúltima aula do ano, primeira semana de dezembro. O número elevado de alunos faltosos foi explicado pela professora pelo fato de a maioria dos professores terem fechado as médias e faltas, após a mostra cultural do último sábado. Mesmo com poucos alunos, a professora discutiu as principais características da civilização romana através de um resumo xerografado. Depois pediu que os alunos fizessem um resumo do texto do livro didático sobre a fundação de Roma, assunto discutido na aula anterior.

Enquanto os alunos faziam a atividade, era executado um $c d$ com sucessos dos anos 70 e 80 da mãe da aluna Joice, pois a professora havia prometido que, na última semana de aula, levaria o aparelho de som em todas as aulas. Entre as músicas executadas, a maioria conhecia a canção "Stayin' Alive" dos Bee Gees, trilha sonora do filme "Os embalos de sábado à noite” (1977), uma das músicas de maior sucesso da discothèque ou disco music da segunda metade dos anos 70 .

Nesses dois momentos de audição coletiva que não foram direcionados pela professora, observei que a música foi utilizada como fundo acústico a fim de criar atmosferas ou ambientes sonoros, inclusive no preenchimento de lacunas deixadas pela ausência de conversação ou interação entre os alunos no decorrer da aula. A formação desse fundo sonoro 
pode ser caracterizado como o que HURON, citado por ILARI (2006), denominou "paisagem sonora".

Perceber e pensar a música como parte de uma paisagem sonora mais abrangente é um assunto relativamente novo na história da etnomusicologia. Foi o compositor e musicólogo canadense Schafer quem forjou a noção de soundscape como o meio ambiente sonoro do homem. Na verdade, trata-se da contraparte acústica da paisagem que circunda os seres humanos. Deve-se distinguir entre dois tipos de paisagens sonoras: uma natural e outra cultural. O soundscape natural envolve sonoridades que provêm de atividades ou ações físicas de fenômenos naturais. Já soundscapes culturais resultam de todo tipo de atividades humanas, como as observadas entre os alunos e a professora. Marcam, em especial, o potencial comunicativo, emocional e expressivo do som. Chegar-se à música através do soundscape é um trajeto complexo. Seria demasiado simplista assumir que a música fosse apenas "destilada" do soundscape, justamente por também ocorrer o processo inverso, ou seja, segundo PINTO (2001:248), a música tem a propriedade de influenciar e mesmo de caracterizar "paisagens sonoras"

Uma paisagem sonora é tão diversificada quanto são diversos os ambientes que a produzem. No caso da sala de aula observada, estará sempre impregnando a primeira impressão que se tem em campo e que se manifesta, infalivelmente, independente se há ou não discernimento prévio daquilo que o acontecimento sonoro significa. No caso específico dessas duas audições, notamos que as músicas que compunham a paisagem sonora para as atividades pedagógicas eram sucessos da década de 70 e 80, referências musicais dos pais dos alunos e também da professora, criando conexões entre a história de vida de cada aluno com o ambiente doméstico e a sala de aula. Mesmo porque, essas canções não representavam o gosto musical da maioria dos alunos da sala que se identificavam, em sua maioria, com artistas do funk (59\%) e da chamada música Black norte-americana (34\%), bem como alguns artistas do Pop / Rock nacional e internacional da última década (53\%), com algumas citações de artistas mais antigos como: Legião Urbana, Black Sabbath, Ira, Lulu Santos, Queen, Raul Seixas e Sandy \& Junior já evidenciam reflexos da influência da família e da professora no gosto musical dos alunos (anexo III - tabela 3).

Quando se fala em ouvir e entender música, mesmo como fundo acústico que cria uma "paisagem sonora", fala-se da "percepção" musical. Entende-se como percepção o processo através do qual o ser humano organiza e vivencia informações basicamente de origem sensória. Longe de existir um consenso, música e sua percepção cognitiva é assunto que já causou polêmica entre representantes de diversas áreas de conhecimento. 
Assim, há autores como PINTO (2001: 236-237) que acreditam em processos cognitivos como universais de natureza, pois cada ser humano dispõe de um sistema nervoso. A visão oposta, que se trabalha nesta pesquisa, já enxerga na diversidade cultural a predisposição para uma preferência e seleção naturais dos padrões visuais e auditivos, fazendo de cada processo cognitivo um caso específico e culturalmente impregnado.

Com base em dados empíricos, a pesquisa musical pode ajudar a detalhar diferenças cognitivas no processo de percepção sonora, que, no nosso caso, se remete à construção do conhecimento histórico em sala de aula e que também pode estar ligado a outros tipos de linguagem, como a escrita e o desenho.

\section{A relação entre "paisagens sonoras" e a linguagem pictórica}

Na segunda semana, a professora apresentou o conteúdo sobre a cidade- Estado de Atenas, discutindo um texto do livro didático ${ }^{14}$ "A educação do jovem ateniense". Chamou a atenção para os três princípios básicos da educação ateniense: leitura, ginástica e música, caracterizando e ressaltando a importância da última para os gregos, já que era instrumental, acalmava e harmonizava a vida dos alunos na Grécia Antiga. Após a leitura coletiva (um parágrafo para cada aluno) e as intervenções explicativas da professora, foram destacadas várias palavras do texto para que os alunos fizessem uma pesquisa obrigatória de vocabulário em casa valendo nota de participação. A professora solicitou uma pesquisa obrigatória sobre a cultura grega antiga e atual em relação à culinária e à música grega, como também sobre a música "Mulheres de Atenas" (1976) e o seu autor Chico Buarque de Holanda (facultativa), para ser inserida na elaboração de vários painéis sobre a cultura grega.

O trabalho dos painéis valeria nota no final do terceiro bimestre e, dependendo da qualidade apresentada, poderia dispensar o aluno da prova. Segundo a professora, a sala de leitura seria o principal espaço para essa pesquisa, pois lá os alunos encontrariam o material para a pesquisa (livros e revistas) e sua execução (cartolinas, colas, canetas, lápis, folha de almaço etc.)

Após os alunos terem feitos as suas pesquisas, receberem a letra e cantarem junto com a professora a canção "Mulheres de Atenas" nas aulas anteriores, na terceira semana observei os alunos fazendo uma atividade individual em relação à canção, na qual retratavam uma

\footnotetext{
${ }^{14}$ COTRIM, Gilberto. Saber e fazer a história, $5^{\text {a }}$ Série. São Paulo: Saraiva, 2002.
} 
parte da mesma por meio de um desenho no qual colocavam uma legenda, levando em conta principalmente a criatividade. Essa atividade complementava a avaliação sobre cultura grega iniciada na semana anterior, enquanto os alunos desenvolviam a atividade escutando a música de Chico Buarque ao fundo, a professora os fotografava trabalhando em sala de aula. Portanto, a linguagem musical era complementada por outra forma de expressão que foi o desenho. Duas semanas depois, a professora mostrou-me os desenhos dos alunos, que, em maioria, retratavam principalmente a questão dos cuidados com a beleza feminina, alimentação com destaque para o leite e o vinho, a religiosidade grega com alguns símbolos cristãos, além da condição de submissão dos escravos. Por serem exemplos de representação ${ }^{15}$ que relacionam o texto do livro didático à canção ouvida em sala de aula, a utilização dos desenhos como atividade complementar à linguagem musical foi encarada com naturalidade pelos alunos, pois a música acabou formando várias "paisagens sonoras" que foram expressas através da linguagem pictórica. Assim como podemos traduzir em palavras um determinado ambiente, podemos traduzi-lo também em desenhos sonoros que são a descrição da paisagem musical desses ambientes. Toda paisagem musical possui recortes, ou seja, elementos distintos que a compõe. Chamamos esses recortes de imagens sonoras, isto é, acontecimentos auditivos que formam a paisagem sonora ambiental, remetendo-nos a visões pictóricas e a sinais visuais. Utilizo o termo imagem sonora como toda informação sonoro-ambiental que compõe a paisagem musical e toda informação sonora que é acrescida ao ambiente, torna-se, naquele momento, parte integrante da paisagem sonora; descrevê-las é como olhar a nossa volta e traduzir os sons que ouvimos através de uma representação gráfica ou da memória de uma série televisiva. Algo destacado por alguns alunos durante as entrevistas.

\footnotetext{
15 "Tal como os discursos, as imagens têm o real como referente, não sendo a sua mímesis. As imagens podem, contudo, ser reconhecíveis ou estranhas, na medida em que se propõem reproduzir o real, de forma realista, a representá-lo de maneira cifrada ou simbólica, decompô-lo e transformá-lo, deformando-o. (...) Imagens, sejam gráficas ou pictóricas, são reapresentações do mundo elaboradas para serem vistas. Como diz AUMONT, elas não são produzidas senão com esse fim”. (PESAVENTO, 2003: 85).
} 
Relação entre os textos, as músicas e outras linguagens trabalhadas em sala de aula (apêndice V - tabela 4)

\begin{tabular}{|c|c|c|}
\hline Textos, músicas e outras linguagens & Sim & Não \\
\hline Texto 1 - Comunidades Tribais e a minissérie "A muralha" & 1 & 7 \\
\hline $\begin{array}{l}\text { Texto } 2 \text { - Civilizações do Oriente Próximo (Egito e Mesopotâmia) e elaboração de } \\
\text { desenhos }\end{array}$ & 1 & 7 \\
\hline Texto 3 - As Mulheres da Grécia Antiga e elaboração de desenhos & 1 & 7 \\
\hline $\begin{array}{l}\text { Texto } 4 \text { - A Urbanização de São Paulo (final do século XIX e inicio do século XX) e a } \\
\text { minissérie "A muralha“" }\end{array}$ & 3 & 5 \\
\hline $\begin{array}{l}\text { Texto } 4 \text { - A Urbanização de São Paulo (final do século XIX e inicio do século XX) e a } \\
\text { elaboração de cartazes com gravuras }\end{array}$ & 2 & 6 \\
\hline
\end{tabular}

As imagens sonoras propiciadas pelas canções executadas pela professora fizeram com que, durante as entrevistas, metade (4) dos alunos se lembrasse dos desenhos e das representações gráficas elaboradas em sala de aula, ou associassem as canções às imagens televisivas da minissérie “A muralha”. Isso evidencia a importância da relação das linguagens visuais com a linguagem musical.

\section{A audição sensível, expressiva e significativa produzindo empatia}

Para melhor entendermos alguns pontos da relação que buscamos estabelecer entre "paisagem sonora" e a linguagem pictórica, faz-se necessária uma breve aproximação do pensamento de COPLAND (1974: 22). Esse compositor americano divide a audição musical hipoteticamente em três planos para melhor compreensão: o plano sensível, o plano expressivo e o plano puramente musical, os quais se misturam naturalmente durante as audições.

No caso dos alunos observados, posso dizer que se encontravam no plano sensível, quando o ouvinte é bombardeado por uma quantidade de som sem se preocupar com origens, formas, timbres, tessituras... Trata-se da forma mais simples de audição musical do plano em que nós ouvimos música sem pensar, pois a mera percepção do som já é capaz de produzir um estado mental provido de muitas sensações e poucas ideias. Isso pode ser constatado pordos sorrisos, caretas e as primeiras tentativas de reconhecimento do ritmo e o acompanhamento das letras por parte dos alunos. 
Já o plano expressivo apareceu mais a partir da segunda audição, quando os alunos começaram atribuir significados à canção, pois toda música possui significado ${ }^{16}$, independente do que o próprio compositor pode nos descrever em seus comentários sobre a obra. Nesse plano, os alunos ficaram mais atentos à letra da canção e aos comentários da professora, que mais tarde foram explorados através da linguagem escrita e pictórica.

Quanto ao plano puramente musical, não apareceu durante as audições, pois tanto os alunos e a professora não tinham um conhecimento técnico e estético desse tipo de linguagem. Para isso, haveria necessidade de compreensão mais apurada da arte musical, buscando entender-lhe formas, tessituras, instrumentação, origens...

A audição coletiva em sala de aula representa a conjunção do plano sensível com o plano expressivo, colocando os alunos e a professora em um mesmo plano de entendimento da audição, formando um plano significativo, quando se tornaram um pouco mais atentos, buscando um sentido, um significado para os sons que ouviam. E mesmo ainda não tão preocupados com efeitos ou conceitos estéticos, tronaram-se mais atentos à canção. Esse tipo de audição, encontrado algumas vezes durante as observações desta pesquisa, foi um dos elementos que explicaram a empatia entre alunos e professora estimulada pela linguagem musical em sala de aula.

Na psicologia, a empatia é um exemplo de inteligência emocional que mistura dois tipos de comportamento: o cognitivo - relacionado à capacidade de compreender a perspectiva psicopedagógica de aprender dos alunos; e o afetivo - relacionado à habilidade de experimentar reações emocionais por meio da observação da experiência dos mesmos. A música, por sua vez, faz com que o componente comportamental da empatia caracterize-se ainda mais, por transmitir, de forma verbal e não verbal, um reconhecimento explícito dos sentimentos e da perspectiva da outra pessoa, de tal maneira que ela se sinta realmente compreendida.

As audições em sala de aula revelam um desenvolvimento da empatia dentro de um continuum, começando com manifestações consideradas pré-empáticas, que aparecem na forma de uma manifestação emocional ressonante, tal como um contágio emocional proporcionado pelas primeiras audições das canções caracterizadas pelas primeiras tentativas de reconhecimento do ritmo e o acompanhamento das letras por parte dos alunos. No final desse continuum, encontram-se as manifestações empáticas, envolvendo interpretações

\footnotetext{
16 “A minha própria opinião é de que todo música tem o seu poder expressivo, algumas mais e outras menos, mas todas têm um certo significado escondido por trás das notas, e esse significado constitui , afinal, o que uma determinada peça está dizendo, ou o que ela pretende dizer". (COPLAND, 1974: 23).
} 
acuradas de sinais afetivos e cognitivos mais sutis dos alunos, que podem ser explorados através da linguagem escrita e pictórica. Agora, pergunta-se até que ponto essa empatia afetiva proporcionada pela linguagem musical se transforma em representações e interfere na consciência histórica dos alunos. Trata-se de uma questão que só será respondida no próximo capítulo, com uma análise mais aprofundada das representações contidas nas oito entrevistas com os alunos.

\section{A música e a linguagem escrita}

Na quarta semana de observação, a professora aplicou uma avaliação relativa à canção "Mulheres de Atenas". Antes de iniciarem a atividade, os alunos escutaram a música duas vezes cantando com a letra em mãos e no final das duas audições aplaudiram. Segundo a professora, tratava-se de um estímulo para os alunos responderem a avaliação com questões dissertativas.

A avaliação foi dividida em três partes: 1) identificar ideias importantes referentes ao texto do livro didático "A educação do jovem ateniense"; 2) identificar ideias importantes da letra da música referentes à condição social das mulheres de Atenas; 3) relacionar a situação das mulheres de Atenas com a condição de vida das mulheres contemporâneas (relação diacrônica). Enquanto os alunos faziam a avaliação, a música do Chico Buarque era executada como ambientação sonora para os alunos responderem a atividade. Ao término, a professora lhes pediu que copiassem a letra e a apresentassem até a próxima aula para verificação. A professora também destacou o silêncio e a disciplina dos alunos durante a execução das tarefas.

A quinta aula de observação teve início de forma expositiva, com a professora falando sobre a cidade- Estado de Esparta e a educação voltada para o militarismo. Essa aula foi baseada no texto do livro didático, com os alunos que se oferecendo para ler os parágrafos e a professora escolhendo o leitor da vez. A leitura foi entremeada de intervenções explicativas da professora, que acabou levando à discussão de qual seria o melhor sistema educacional. A maior parte dos comentários dos alunos tratou de um sistema rigoroso, tanto em termos de avaliação, como também em termos disciplinares, já que,para eles, qualquer tipo de desobediência deveria acarretar severas sanções. Esse procedimento levou a professora chamar a minha atenção, após a aula, de como os alunos são rigorosos consigo mesmos e como eles sugeriram, a partir das falas, o estabelecimento de limites. Antes de terminar a aula, 
a professora Marli devolveu a avaliação dissertativa sobre a canção "Mulheres de Atenas". O rendimento foi considerado plenamente satisfatório pela docente.

A minha sexta semana de observação se iniciou com a professora pedindo aos alunos que trouxessem os trabalhos elaborados sobre pré-história brasileira e os índios, pois fariam parte da mostra cultural da escola cujo tema seria "São Paulo espaço e memória”. Depois foram colocadas nove questões na lousa sobre o texto do livro didático "Expansão de Atenas" que deveriam ser respondidas pelos alunos enquanto ela vistava os cadernos não foram corrigidos na aula anterior, com o conteúdo do segundo semestre (a partir de hebreus).

A maioria das atividades pedagógicas descritas, relacionadas à música de Chico Buarque, exceto os desenhos, privilegiavam a linguagem escrita. A utilização do texto legitimou, de certa forma, a prática pedagógica com a linguagem musical, pois o texto permite levar mais longe o deslocamento da veracidade à verossimilhança, pondo em discussão os efeitos de real e de verdade que uma narrativa histórica pode produzir, tomando o lugar do que teria acontecido um dia. Ao trabalhar com a linguagem musical como documento, a professora se deparou, forçosamente, com a necessidade de pensar o estatuto do texto da letra da canção, do livro didático e da avaliação escrita dos alunos, para realizar cruzamentos entre a linguagem escrita e a linguagem musical, em suas aproximações e distanciamentos. Algo que pode ser destacado pelas três tabelas abaixo.

Identificação dos temas através dos textos (apêndice $V$ - tabela 1)

\begin{tabular}{|c|c|c|}
\hline Temas e textos & Sim & Não \\
\hline Texto 1 - Comunidades Tribais & 7 & 1 \\
\hline Texto 2 - Civilizações do Oriente Próximo (Egito e Mesopotâmia) & 8 & - \\
\hline Texto 3 - As Mulheres da Grécia Antiga & 6 & 2 \\
\hline Texto 4 - A Urbanização de São Paulo (final do século XIX e início do século XX) & 7 & 1 \\
\hline
\end{tabular}


Relação entre os textos e as músicas ouvidas em sala de aula (apêndice V - tabela 2)

\begin{tabular}{|c|c|c|}
\hline Textos e músicas & Sim & Não \\
\hline $\begin{array}{l}\text { Texto } 1 \text { - Comunidades Tribais e "Curumim chama cunhatã que eu vou cantar (todo dia } \\
\qquad \text { era dia de índio)" (Jorge Ben Jor e Tim Maia) }\end{array}$ & 7 & 1 \\
\hline $\begin{array}{c}\text { Texto } 2 \text { - Civilizações do Oriente Próximo (Egito e Mesopotâmia) e "Planeta água” } \\
\text { (Guilherme Arantes) }\end{array}$ & 4 & 4 \\
\hline $\begin{array}{c}\text { Texto } 3 \text { - As Mulheres da Grécia Antiga e "Mulheres de Atenas" (Chico Buarque de } \\
\text { Holanda) }\end{array}$ & 6 & 2 \\
\hline $\begin{array}{l}\text { Texto } 4 \text { - A Urbanização de São Paulo (final do século XIX e início do século XX) e } \\
\text { "São Paulo, São Paulo" (Premê) }\end{array}$ & 8 & - \\
\hline
\end{tabular}

Relação entre os textos e outras músicas sugeridas pelos alunos (apêndice $\mathbf{V}$ - tabela 3)

\begin{tabular}{|c|c|c|}
\hline Textos e músicas & Sim & Não \\
\hline Texto 1 - Comunidades Tribais e "Índios" (Legião Urbana) & 1 & 7 \\
\hline $\begin{array}{c}\text { Texto } 2 \text { - Civilizações do Oriente Próximo (Egito e Mesopotâmia) e "Água mineral" } \\
\text { (Carlinhos Brown) }\end{array}$ & 1 & 7 \\
\hline Texto 3 - As Mulheres da Grécia Antiga & - & - \\
\hline Texto 4 - A Urbanização de São Paulo (final do século XIX e início do século XX) & - & - \\
\hline
\end{tabular}

Como podemos observar, durante as oito entrevistas $75 \%$ (6) os alunos conseguiram identificar todos os temas através dos textos utilizados como estímulos durante as entrevistas, sendo que, dos entrevistados, metade (4) relacionou todos os textos com todas as músicas trabalhadas pela professora no ano anterior. Outro aspecto a se destacar é que apenas metade (4) dos alunos relacionaram o texto 2 "Civilizações do Oriente Próximo (Egito e Mesopotâmia)" com a música "Planeta água" de Guilherme Arantes, porque e foi utilizada apenas como estímulo para introduzir o tema das chamadas "civilizações hidráulicas". Quando foi solicitado aos alunos relacionarem outras canções que conheciam com os temas propostos pelos textos nas entrevistas, apenas $25 \%$ (2) dos alunos conseguiram responder.

Essas duas últimas observações revelam que, se a letra não fosse trabalhada como um texto relacionado diretamente ao conteúdo histórico pela professora, os alunos teriam muita dificuldade de relacionar a linguagem musical ao conteúdo histórico, o que reforça ainda mais a importância de um cruzamento efetivo ente a linguagem escrita e musical para o entendimento e a fixação dos conteúdos na sala de aula. 


\section{A tradição cultural da MPB e a escolha do repertório}

Além das relações da linguagem musical com a pictórica e o texto escrito, outra questão deve ser abordada. Trata-se da escolha do repertório, que não está apenas relacionada ao gosto e à trajetória de vida e profissional da professora, que discutirei mais adiante, mas também a uma tradição cultural da MPB (Música Popular Brasileira), consolidada nos anos 80 e 90 e que ainda se mantém nos dias de hoje.

Apesar do estrondoso sucesso comercial do rock brasileiro dos anos 80 e dos gêneros populares dos anos 90 (sertanejo, pagode e axé e funk), estigmatizados pela classe média herdeira do "bom gosto" musical, não foram esquecidos outros tipos de gêneros. Os "monstros sagrados" da MPB - Chico Buarque, Caetano Veloso, Gilberto Gil, Maria Bethania, Milton Nascimento, Gal Costa, Djavan, entre outros - ainda permanecem como tops no cenário musical brasileiro, inclusive do ponto de vista comercial (se não em números absolutos, em valores agregados e relativos como referências para as gerações do que se considera a "boa" música popular brasileira

O rock brasileiro dos anos 80 , por exemplo, não chegou a negar a tradição poéticomusical da MPB, como poderia parecer à primeira vista. A adesão de Lobão ao samba, Lulu Santos à Bossa Nova e Arnaldo Antunes aos procedimentos poéticos do tropicalismo/concretismo, entre outras trajetórias, mostra a força catalisadora desses movimentos. No final de século XX, quando a indústria fonográfica passa por uma nova crise de mercado, a MPB ainda fornece as balizas para o consumo da classe média, herdando o reconhecimento cultural adquirido entre o final dos anos 50 e a década de 70. Essas décadas, conforme NAPOLITANO (2000:75), marcam uma historicidade que parece ter assistido à última grande sistematização da tradição e da memória musical brasileira.

Também reproduzida no âmbito escolar, essa tradição cultural não invalida a sua utilização. Como qualquer outro tipo de música, a MPB imana uma pluralidade de memórias e projetos culturais, quase sempre conflitivos entre si e que se manifestam em maior, ou em menor grau na sala de aula. Não cabe aqui analisarmos as representações contidas nos desenhos, nas avaliações, ou nos painéis elaborados pelos alunos, mas a natureza deles, motivada pelas músicas do Preme e dê Chico Buarque, pois todos aqueles que se arriscam trabalhar com a canção popular como linguagem, também devem levar em conta a suposta condição excessivamente subjetiva como dificuldade adicional. Isso porque a música, além de seu estado de imaterialidade, atinge os sentidos do receptor, estando, portanto, fundamentalmente no universo da sensibilidade. 
Por tratar-se de um material marcado por objetivos essencialmente estéticos e artísticos, destinado à fruição pessoal e ou coletiva, a canção não só assume inevitavelmente a singularidade e características especiais próprias do autor e de seu universo cultural, mas uma nova leitura é realizada pelo receptor (alunos), às vezes trilhando caminhos inesperados para o criador e para o professor. Será justamente essa releitura repleta de representações elaboradas pelos alunos, que analisarei através de algumas entrevistas no próximo capítulo. 


\section{CAPÍTULO 4- AS INFLUÊNCIAS DA LINGUAGEM MUSICAL NAS REPRESENTAÇÕES E NA CONSCIÊNCIA HISTÓRICA DOS ALUNOS}

A terceira fase da pesquisa foi realizada em junho de 2008, composta por oito entrevistas com os alunos, que já frequentavam a $6^{\mathrm{a}}$ série do Ensino Fundamental, e uma com a professora, em maio de 2009. As entrevistas configuram uma amostragem qualitativa dos estudantes observados e da professora, fazendo parte da construção da leitura de um objeto de pesquisa que valorize o discurso e a experiência pessoal do entrevistado durante as aulas que foram observadas.

O modo como os alunos interagem com os saberes disciplinares e curriculares por intermédio da ação do professor constitui-se em um objeto essencial para este tipo de pesquisa de campo, principalmente se levarmos em conta as representações históricas que os alunos possuem em relação a esses conteúdos. As representações históricas dos professores e alunos, construídas pela audição de composições musicais, podem ser eficazes auxiliares na construção do conhecimento histórico, pois propiciam a identificação diferentes significados dos elementos definitivos e provisórios contidos nas representações históricas ${ }^{17}$, que podem se transformar em uma ponte entre o presente e o passado histórico.

A representação como uma forma de discurso deve considerar a prática social do sujeito na construção da representação, determinar a dinâmica das representações pelo jogo das relações intergrupais e identificar o sujeito como um portador das determinações sociais responsáveis, em última instância, pela produção das representações (Sá, 2002: 37). A sala de aula, enquanto campo, pode ser vista como um espaço de estudo multidimensional no qual a atividade cognitiva pela qual os sujeitos (professora e alunos) constroem suas representações, acentuam os aspectos significantes da atividade pedagógica. O conceito de representação social aplicado na sala de aula nos faz perceber que não podemos reduzir o processo de aprendizagem a movimentos mecânicos o que sustenta e define as condutas pedagógicas.

17 “As mudanças no presente, experimentadas como carentes de interpretação, são interpretadas em articulação com os processos temporais rememorados do passado; a narrativa histórica torna presente o passado, de forma que o presente aparece como sua continuação no futuro. Com isso a expectativa do futuro vincula-se diretamente à experiência do passado: a narrativa histórica rememora o passado sempre com respeito à experiência do tempo presente e, por essa relação com o presente, articula-se diretamente com as expectativas de futuro que se formulam a partir das intenções e das diretrizes do agir humano dos estudantes e professores entrevistados. Essa íntima interdependência de passado, presente e futuro é conhecida como uma representação histórica e serve à orientação da vida humana prática atual desses sujeitos”. (RÜSEN, 2001: 64). 
A experiência que marca o indivíduo está, em seu aprender, delimitando-o. Nessa perspectiva, aprender e ensinar supõe a articulação contínua entre aluno e professor que atualiza, a cada passo, experiências que se revertem, invertem ou convergem. Os professores, nesse sentido, seriam todos aprendizes e ensinantes, integrando tempos e espaços nas presenças-ausentes ou ausências-presentes, ou seja, mediadores na transformação da consciência histórica do aluno através ensino de História em sala de aula. (Madeira, 2000: 243).

A História Cultural tem como um dos seus objetivos privilegiados as representações do mundo social, identificando o modo como em diferentes lugares e momentos uma realidade social específica é construída e pensada. Esse campo resulta de questões colocadas à História por novas disciplinas, possibilitando desviar os enfoques das hierarquias para as relações e das posições para as representações.

Produtoras de estratégias e práticas sociais diversas, as representações sociais não constituem discursos neutros. A noção de representação social aplicada ao conhecimento histórico, através do discurso dos alunos e da professora, favorece a articulação de três modalidades de relação com o mundo social: 1) o trabalho de classificação e delimitação que produz as configurações intelectuais múltiplas, através das quais a realidade é contraditoriamente construída pelos diferentes grupos; 2) as práticas que visam fazer reconhecer uma identidade social para exibir uma maneira própria de estar no mundo, o que significa, simbolicamente, um estatuto e uma posição; 3) as formas institucionalizadas e objetivadas graças às quais uns "representantes" marcam de forma visível e perpetuada a existência do grupo, da classe ou da comunidade. Essa análise das representações na História Cultural refere-se às classificações e exclusões que constituem, na sua diferença radical, as configurações sociais e conceituais próprias de um tempo ou de um espaço historicamente produzidas pelas práticas articuladas - políticas, sociais e discursivas. (CHARTIER, 1990: 2327).

O jovem de hoje vive num período que se define pela expansão das relações virtuais em inúmeras instâncias sociais, redimensionando as categorias espaço e tempo, relações sociais e culturais, fazendo com que o tempo se torne cada vez mais veloz, e as relações sociais mais voláteis. Nesse tipo de sociedade, cada vez mais as representações sociais são fenômenos específicos que estão relacionados com um modo particular de compreender e de se comunicar entre as pessoas, um modo que cria uma realidade e um senso comum 
(MOSCOVICI 2003: 49), formando um imaginário ${ }^{18}$ particular, que se constitui em algo mais amplo que a ideologia, pois integra "o que não está formulado, o que permanece aparentemente como 'não significante', o que se conserva muito encoberto ao nível das motivações inconscientes" (VOVELLE, 1987: 19).

\section{Discursos, representações e canções}

As entrevistas com os alunos foram estabelecidas a partir dos seguintes critérios: gênero (masculino ou feminino); faixa etária; processo ensino-aprendizagem (maior e menor rendimento, indiferença e comprometimento em relação ao curso em sala de aula). O roteiro das entrevistas com os alunos (apêndice IV) foi elaborado a partir das observações das aulas e da utilização de pequenos textos didáticos (anexo I) que serviram de estímulo para que os entrevistados estabelecessem relações entre as aulas e as músicas trabalhadas em sala de aula com a professora. Com isso, tentei estabelecer uma diversidade dos sujeitos que formaram uma amostra do universo do estudante e do professor, facilitando, assim, as associações e relações que propiciam uma análise da representação histórica deste aluno em relação aos conteúdos desenvolvidos em sala de aula.

A identificação do tema do texto 1 (anexo I) e a relação com música - "Curumim chama cunhatã que eu vou cantar (todo dia era dia de índio)” de Jorge Ben Jor (anexo II música 1) - foi estabelecida por quase todos os alunos (apêndice $V$ - tabelas 1 e 2), o que possibilitou destacar alguns pontos em comum entre os discursos dos entrevistados que resultaram nas representações relacionadas abaixo:

\footnotetext{
18 “O imaginário de que falo não é imagem de. É criação incessante e essencialmente indeterminada (socialhistórica e psíquica) de figuras / formas / imagens, a partir das quais somente é possível falar-se de 'alguma coisa'. Aquilo que denominamos 'realidade' e 'racionalidade' são seus produtos" (CASTORIADIS, 1995: 13).
} 
Identificação do texto 1 relacionando-a à música "Curumim chama cunhatã que eu vou contar (todo dia era dia de índio)" de Jorge Bem Jor (apêndice VI - quadro 1)

\begin{tabular}{|c|c|}
\hline Discursos & Representações \\
\hline $\begin{array}{l}\text { - "O modo de vida deles (indios) cuidando da } \\
\text { terra". } \\
\text { "Sem a madeira a gente fica sem muitas coisas e } \\
\text { eles não cortam a madeira para destruir a } \\
\text { natureza (...). Não pode matar bicho à toa". } \\
\text { "Lembro dos índios que não matavam os animais } \\
\text { apenas porque queriam, agora quando chegaram } \\
\text { os portugueses eles começaram a fazer isso, } \\
\text { matavam e escravizam os índios". } \\
\text { "O texto fala do desmatamento e do cortar as } \\
\text { árvores e dos índios". } \\
\text { "Só retiravam o necessário para a caça, para a } \\
\text { pesca e fazer arcos". } \\
\text { "O texto fala que não podemos matar animais à } \\
\text { toa, apenas para sobreviver no mato, quando o } \\
\text { indio corta o mato ou mata um animal é para } \\
\text { sobreviver". } \\
\text { acabar". }\end{array}$ & $\begin{array}{ll}\text { - } & \text { Preservação da natureza. } \\
\text { - } & \text { Economia de subsistência. } \\
\text { - } & \text { Exploração do português. }\end{array}$ \\
\hline
\end{tabular}

Os alunos que identificaram o tema partiram do texto 1 (anexo I), apresentado durante as entrevistas, mas as representações em relação ao tema "comunidades tribais", foram também construídas a partir relação com a canção, lembrada por eles, através do seu marcante refrão "Todo dia era dia de índio / Todo dia era dia de índio" (anexo II - música 1). As representações de preservação da natureza, economia de subsistência e a exploração dos portugueses também foram estimuladas pela lembrança do seguinte trecho da canção: 


\section{(...) Antes que o homem aqui chegasse}

Às Terras Brasileiras

Eram habitadas e amadas

Por mais de 3 milhões de índios

Proprietários felizes

Da Terra Brasilis (...)

Amantes da natureza

Eles são incapazes

Com certeza

De maltratar uma fêmea

Ou de poluir o rio e o mar

Preservando o equilíbrio ecológico

Da terra, fauna e flora

Pois em sua glória,o índio

É o exemplo puro e perfeito

Próximo da harmonia

Da fraternidade e da alegria (...)

Representações que também foram reforçadas pelos textos do livro didático trabalhados pela professora, como a descrição do arqueólogo Robert Braidwood no texto complementar "Vida na aldeia":

“(...) Após as colheitas, os homens mais jovens podiam sair para a caça, alguns iriam pescar, mas a comida que traziam era apenas um acréscimo à comida existente na aldeia. Os moradores da aldeia não morreriam de fome, mesmo que os caçadores e pescadores voltassem para case de mãos vazias.” (BRAIDWOOD, Robert J. Homens pré-históricos. Brasília: UNB, 1985. P.128. Citado por COTRIM, Gilberto. Saber e fazer a História, $5^{\text {a }}$ Série. $2^{a}$ ed. São Paulo: Saraiva, 2002. P. 46).

Ao contrário do tema anterior, o tema do texto 2 (anexo I), apesar de ser identificado por todos os alunos entrevistados (apêndice V - tabela 1), só metade (apêndice V - tabela 2), relacionou a música com o tema "Civilizações do Oriente Próximo (Egito e Mesopotâmia)". 
Identificação dos temas através dos textos (apêndice $V$ - tabela 1)

\begin{tabular}{|c|c|c|}
\hline Temas e textos & Sim & Não \\
\hline Texto 1 -Comunidades Tribais & 7 & 1 \\
\hline Texto 2 - Civilizações do Oriente Próximo (Egito e Mesopotâmia) & 8 & - \\
\hline Texto 3 - As Mulheres da Grécia Antiga & 6 & 2 \\
\hline Texto 4 - A Urbanização de São Paulo (final do século XIX e inicio do século XX) & 7 & 1 \\
\hline
\end{tabular}

Relação entre os textos e as músicas ouvidas em sala de aula (apêndice $\mathrm{V}$ - tabela 2)

\begin{tabular}{|c|c|c|}
\hline Textos e músicas & Sim & Não \\
\hline $\begin{array}{l}\text { Texto } 1 \text { - Comunidades Tribais e "Curumim chama cunhatã que eu vou cantar (todo dia } \\
\qquad \text { era dia de índio)" (Jorge Ben Jor) }\end{array}$ & 7 & 1 \\
\hline $\begin{array}{c}\text { Texto } 2 \text { - Civilizações do Oriente Próximo (Egito e Mesopotâmia) e "Planeta água” } \\
\text { (Guilherme Arantes) }\end{array}$ & 4 & 4 \\
\hline $\begin{array}{c}\text { Texto } 3 \text { - As Mulheres da Grécia Antiga e “Mulheres de Atenas” (Chico Buarque de } \\
\text { Holanda) }\end{array}$ & 6 & 2 \\
\hline $\begin{array}{l}\text { Texto } 4 \text { - A Urbanização de São Paulo (final do século XIX e início do século XX) e } \\
\text { "São Paulo, São Paulo" (Premê) }\end{array}$ & 8 & - \\
\hline
\end{tabular}

Esse percentual mais baixo em relação à música anterior é explicado pelo fato de a canção "Planeta água” de Guilherme Arantes (anexo II - música 2) ter sido apresentada aos alunos para introduzir o tema das chamadas "civilizações hidráulicas". Essa dificuldade é explicada pelo fato de a letra da canção não tratar diretamente do conteúdo histórico trabalhado pela professora, e a relação entre música e conteúdo ter como ponto de partida a letra da canção.

Os estudantes entrevistados, mesmo aqueles que não se lembraram da canção, identificaram o tema e o relacionaram com o texto da entrevista (anexo I - texto 2), apresentando os seguintes discursos e representações (anexo V - tabela 6): 
Identificação do texto 2 relacionando-o à música “Planeta água” de Guilherme Arantes (apêndice VI quadro 2)

\begin{tabular}{|c|c|}
\hline Discursos & Representações \\
\hline $\begin{array}{l}\text { - "A importância da água para as primeiras } \\
\text { civilizações do Egito e da Mesopotâmia". } \\
\text { - "Lembra sobre o Egito, o Nilo, o Eufrates e a } \\
\text { música, que fala dos vales e dos rios “. } \\
\text { - "O texto trata do Egito, do rio Nilo e do rio Tigre } \\
\text { e da importância dos rios para os agricultores". } \\
\text { "O texto fala do sobre os rios Nilo, Tigre e } \\
\text { Eufrates, o Egito Antigo e a Mesopotâmia. Como a } \\
\text { música que fala da importância da água e faz } \\
\text { lembrar sobre o Egito”.. }\end{array}$ & $\begin{array}{l}\text { - Importância dos grandes rios para } \\
\text { a formação das primeiras } \\
\text { civilizações. } \\
\text { - Preservação da natureza. }\end{array}$ \\
\hline
\end{tabular}

Se todos os alunos identificaram o tema, foi porque partiram do texto 2, apresentado durante as entrevistas (anexo I). As representações em relação ao tema "Civilizações do Oriente Próximo (Egito e Mesopotâmia)", não obstante, foram também construídas através texto do livro didático trabalhado em sala de aula.

"Os povos mesopotâmicos adaptaram-se às condições naturais da região. Assim construíram diques e barragens para conter as enchentes do Tigre e do Eufrates, além de canais de irrigação para levar a água desses rios até os lugares mais secos. (...) Os egípcios construíram grandes canais de irrigação para levar as águas do Nilo às regiões mais distantes de suas margens. Também ergueram diques e barragens para proteger vidas $e$ casas das inundações mais violentas, do mesmo modo como foi feito pelos povos da Mesopotâmia. (...) Com esse sistema de diques e canais, os egípcios conseguiram plantar e obter colheitas abundantes, dominando em grande medida, as águas do Nilo”. (COTRIM, Gilberto. Op. cit. p. 46 / p. 63.)

Já os alunos que conseguiram relacionar a música ao texto 2 e ao tema, lembraram-se dela, "como a música que fala da importância da água e faz lembrar sobre o Egito" (anexo II - música 2). 
“Águas escuras dos rios

Que levam

A fertilidade ao sertão

Águas que banham aldeias

E matam a sede da população... (...)

Na inundação...

Águas que movem moinhos

São as mesmas águas

Que encharcam o chão

E sempre voltam humildes

Pro fundo da terra

Pro fundo da terra...

Terra! Planeta Água

Terra! Planeta Água

Terra! Planeta Água..”

A identificação do tema do texto "As mulheres da Grécia Antiga" (anexo I - texto 3) e a relação do mesmo com a canção "Mulheres de Atenas" de Chico Buarque de Holanda (anexo II - música 3) foi estabelecida por 75\% dos alunos (apêndice V - tabelas 1 e 2), resultando nos seguintes discursos e representações: 
Identificação do texto 3 relacionando-o à música “Mulheres de Atenas" de Chico Buarque de Holanda (apêndice VI - quadro 3)

\begin{tabular}{|c|c|}
\hline Discursos & Representações \\
\hline "A vida das mulheres de Atenas na Grécia Antiga, & $\bullet$ A condição inferior e de \\
pois os pais é que escolhiam o casamento e & dependência social das mulheres \\
pagavam para que elas arrumassem um marido". & em relação aos homens (pais e \\
- "Lembro de Atenas onde os homens não & maridos). \\
respeitavam as mulheres". & Apresentação de algum tipo de \\
"O texto me fez lembrar que a professora falou & resistênciação è à \\
que colocavam as mulheres no prédio e \\
queimavam na Grécia. Isso me fez lembrar da \\
música. Elas foram queimadas porque elas se \\
revoltaram". \\
"O texto fala das mulheres e dos maridos na \\
Grécia. Como a música que fala das mulheres que \\
só tinham um cômodo pra elas e só podiam \\
trabalhar em casa. Os maridos iam para a guerra, \\
quando ficavam de quarentena e não podiam \\
comer alguma coisa ou fazer alguma coisa".
\end{tabular}

As representações construídas pelos alunos, ao contrário dos temas anteriores, não tiveram influência do texto do livro didático, pois os estudantes partiram do texto (anexo I texto 3) e o relacionaram com a música de Chico Buarque, destacando a condição de inferioridade das mulheres gregas. 
"Mirem-se no exemplo

Daquelas mulheres de Atenas

Sofrem pros seus maridos

Poder e força de Atenas

Quando eles embarcam soldados

Elas tecem longos bordados

Mil quarentenas

E quando eles voltam, sedentos

Querem arrancar, violentos

Carícias plenas, obscenas (...)

Geram pros seus maridos

Os novos filhos de Atenas

Elas não têm gosto ou vontade

Nem defeito, nem qualidade

Têm medo apenas

Não tem sonhos, só tem presságios"

Tanto nesse tema como no anterior, relacionados às "Civilizações do Oriente Próximo (Egito e Mesopotâmia)", a professora solicitou que os alunos elaborassem desenhos que retratassem os temas e suas respectivas canções, fazendo com que $25 \%$ dos alunos relacionassem essa linguagem aos temas (apêndice V - tabela 4). Para dois alunos os desenhos foram importantes na construção das suas representações, pois também possibilitaram o cruzamento dos textos apresentados durante as entrevistas, com as canções, o texto do livro didático e o discurso da professora em sala de aula.

Outro destaque importante foi o destaque dado por um aluno à fala da professora em suas aulas de Grécia Antiga. Procurou relacionar o texto da entrevista com o discurso da docente:

"O texto me fez lembrar que a professora falou que colocavam as mulheres no prédio e queimavam na Grécia. Isso me fez lembrar da música. Elas foram queimadas porque elas se revoltaram " (apêndice VI - quadro 3). 
O aluno lembrou-se da relação diacrônica construída pela professora por meio de analogias ${ }^{19}$ entre a condição de inferioridade da mulher ateniense e a resistência contra a luta das mulheres operárias no século XIX, citando como exemplo a greve de operárias tecelãs de Nova Iorque, que reivindicavam melhores condições de trabalho e salário. A manifestação foi reprimida com forte violência, pois as mulheres foram trancadas dentro da fábrica, que foi incendiada. Aproximadamente 130 tecelãs morreram carbonizadas.

$\mathrm{Na}$ verdade, o aluno construiu uma representação anacrônica através de uma relação diacrônica estabelecida pela professora em sala de aula. Apesar do erro histórico, trata-se de algo comum entre os alunos quando o professor estabelece esse tipo de relação, porém tal engano cometido pelo aluno permite a identificação do tema e a construção de sua representação sobre o mesmo, que poderá ou não ser corrigido durante a sua trajetória de vida, mas é algo que lhe compõe a consciência histórica, faz parte da sua representação e permite a identificação do tema.

"É preciso usar de anacronismo para ir em direção da Grécia antiga com a condição de que o historiador assuma o risco de colocar precisamente de seu objeto grego questões que já não sejam gregas; de que aceite submeter seu material antigo a interrogações que os antigos não se fizeram ou pelo menos não formularam ou, melhor, não recortaram como tais" (LORAUX, 1992: 61).

Para se compreender os homens do passado, devemos, portanto, partilhar algo de sentimentos, pensamentos e perspectivas deles. Trata-se da busca do anacrônico para se chegar ao diacrônico, ou seja, trata-se do paradoxo entre a necessária paixão pelo assunto e o igualmente necessário racionalismo para tratá-lo, algo feito pela professora na aula e recuperado pelo aluno um ano depois, durante a entrevista. Historiadores, professores e alunos estão sempre em uma tensa faixa tênue que marca a distinção entre estes dois limites opostos: anacronismo e diacronismo.

O tipo de ponte construída a partir de uma relação diacrônica, também é marcante em relação ao tema quatro "A Urbanização de São Paulo (final do século XIX e inicio do século XX)", pois o texto (anexo I - texto 4) utilizado durante as entrevistas forçava essa relação por meio da comparação com a música "São Paulo, São Paulo” do grupo Preme (anexo II -

19 “(...) a analogia se configurou em recurso pertinente para auxiliar os alunos a avançar no processo de construção de conceitos. O professor recorreu, também, a comparações para promover a compreensão do tema em estudo por meio de sua contextualização na 'realidade' do aluno, no tempo presente" (MONTEIRO, 2005: 341). 
música 4), que retrata a rápida urbanização de São Paulo na segunda metade do século XX. Todos os alunos relacionaram a música ao texto motivador da entrevista, mas apenas um deles não conseguiu identificar o tema (apêndice V - tabelas 1 e 2), pois não estabeleceu uma relação diacrônica entre o texto e a canção, colocando-as no mesmo plano em relação ao passado: "o texto e a música falam de São Paulo de antigamente”. Já os demais apresentaram discursos e representações que, de certa forma, foram marcadas por uma relação de diacronismo.

Identificação do texto 4 relacionando-a à música "São Paulo, São Paulo" do Preme (apêndice VI - quadro 4)

\begin{tabular}{|c|c|}
\hline Discursos & Representações \\
\hline $\begin{array}{l}\text { - } \text { "O surgimento de São Paulo e como a cidade foi } \\
\text { evoluindo até hoje, falando dos bondes. Lembro de } \\
\text { uma música que cantava sobre São Paulo e dos } \\
\text { bairros no final do século XX“. } \\
\text {-O texto fala dos bairros que foram levantados } \\
\text { rapidamente em São Paulo no final do século XIX. } \\
\text { Eu lembro que ela (professora) passou uma } \\
\text { música que falava sobre os bairros, tipo Bom } \\
\text { Retiro". } \\
\text { "Melhorias urbanas de São Paulo no século XIX. } \\
\text { Lembrei da música porque falava dos bairros, } \\
\text { como a Casa Verde“. } \\
\text { "O texto fala de algumas construções como o } \\
\text { Viaduto do Chá e de São Paulo de hoje, como a } \\
\text { música que fala das pessoas morando na grande } \\
\text { cidade em um BNH, que são vários prédios”. } \\
\text { "O texto fala como era São Paulo antes ate o final } \\
\text { do século XIX, primeiro vieram as carroças } \\
\text { puxadas por burros levando as coisas, depois veio } \\
\text { a luz elétrica, avenidas e ruas e a música fala de } \\
\text { como as pessoas vieram parar em São Paulo e } \\
\text { quando foi descoberta antigamente. A música } \\
\text { lembra 'New York, New York”." }\end{array}$ & $\begin{array}{l}\text { - A urbanização de São Paulo através } \\
\text { das seguintes representações: } \\
\text { Formação dos seus bairros. } \\
\text { Grandes obras públicas. } \\
\text { - Desenvolvimento dos meios de } \\
\text { transporte. } \\
\text { - Desenvolvimento tecnológico. } \\
\text { - Símbolo de transformação e } \\
\text { modernidade. } \\
\text { Polo de atração e concentração } \\
\text { humana. }\end{array}$ \\
\hline
\end{tabular}




\begin{tabular}{|l|l|}
\hline Discursos & Representações \\
\hline - "O texto fala de São Paulo de antigamente e dos & \\
seus bairros como Brás, Luz, Barra Funda e o Rio & \\
Tietê. Como a música que fala desses bairros & \\
atualmente. \\
- "O texto fala de como foram criados os transportes & \\
e alguns bairros de São Paulo de antigamente. & \\
Como a música que fala dos bairros Brás e & \\
Bexiga".
\end{tabular}

No caso do tema quatro em relação à urbanização de São Paulo, as representações do processo de urbanização encontram-se intimamente ligadas às ideias de desenvolvimento, progresso, modernidade e crescimento populacional e modernidade, elementos que também foram associados, por um aluno, à cidade de Nova Iorque, algo provocado pelo arranjo da música do grupo Premê, que apresenta citações da famosa canção "New York, New York", imortalizada na interpretação de Frank Sinatra (1980).

Quanto às relações diacrônicas elaboradas pelos alunos durante as entrevistas tiveram como referência o espaço urbano simbolizado pelos bairros paulistanos e que fazem parte, direta ou indiretamente, da vida desses alunos, pois tanto o texto 4 (anexo I) quanto à letra da canção (anexo II - música 4) destacam o espaço urbano como referência histórica.

"Na periferia a fábrica escurece o dia

Chora Menino, Freguesia do Ó, Carandiru, Mandaqui

$$
\text { (aqui!) }
$$

Vila Sônia, Vila Ema, Vila Alpina, Vila Carrão,

Morumbi - Pari

Butantã, Utinga, M Boi Mirim, Brás, Brás, Belém

Bom Retiro, Barra Funda, Ermelino Matarazzo, Mooca,

Penha, Lapa, Sé

Jabaquara, Pirituba, Tucuruvi, Tatuapé (...)

Um ponto de partida pra subir na vida em São Paulo (em São Paulo)

Terraço Itália, Jaraguá, Viaduto do Chá (...) 
Na verdade, os bairros só deixaram o anonimato, passando a fazer parte da história de São Paulo em direção ao desenvolvimento e o progresso, no final do século XIX, com a industrialização e as grandes obras de urbanização da cidade, reflexo da expansão da economia cafeeira. Como a construção do viaduto do Chá (1892), que foi fundamental para a expansão urbana da capital paulista e é citado como referência histórica tanto na letra da canção como no texto (anexo I - texto 4) utilizado na entrevista.

"Até o final do século XIX, São Paulo ainda guardava um aspecto provinciano. $O$ núcleo urbano central, em torno do Pátio do Colégio, onde a cidade nasceu, não havia ultrapassado os vales do Anhangabaú e do Tamanduateí. Havia ainda muitos espaços vazios, chácaras e sítios. A construção do primeiro viaduto, o do Chá, inaugurado em 1892, foi fundamental para a expansão urbana.

Abriu-se então uma nova era de reformas e progressos (...). Os trilhos das ferrovias rasgaram as áreas planas vizinhas aos rios Tietê e Tamanduateú, regiões alagadiças que até então haviam permanecido praticamente desertas. Armazéns, depósitos, oficinas e indústrias foram atraídos pela facilidade dos transportes. Os terrenos relativamente baratos foram sendo ocupados pelos imigrantes. Novos bairros surgiram, como, por exemplo, Brás, Luz, Barra Funda, Bom Retiro, Mooca, Belenzinho. (...)” (LUCA, Tania Regina de. Café e modernização. São Paulo. Atual, 2000. Pp.29-32 - A vida no tempo).

A apresentação de diferentes espaços de uma cidade, com suas particularidades e contradições e, principalmente, com pessoas concretas vivendo nela, contribui para a construção da consciência histórica, na medida em que os alunos passam a ter uma ideia de como os diferentes grupos viveram e se organizaram no espaço urbano. Essa reconstrução histórica permite aflorar o sentimento de pertença e de cidadania, à proporção que os alunos poderão refletir, selecionar, escolher marcas espaciais significativas, enfim, identificar bens culturais que se quer coletivamente preservar apropriar e usufruir. Dessa forma, ao possibilitar ao aluno reconhecer-se como parte de uma memória comum, criadora de identidade, estará se concedendo melhor compreensão do espaço de que é herdeiro, possibilitando-o desempenhar um papel ativo na sociedade, pois não é possível integrar-se plenamente à cultura de uma cidade se não se apropriar da herança histórica que a estrutura.

A concepção de tempo está ligada às grandes cidades, pois o tempo delas é marcado por mudanças, transformações e destruições, contrastando com outros tempos, isto é, o das permanências, da continuidade e da memória. Esses contrastes entre as mudanças e 
permanências compõem obrigatoriamente as relações diacrônicas, as representações e a formação da consciência histórica em relação à realidade vivida pelos alunos na cidade.

O texto 4 (anexo I) e a canção "São Paulo, São Paulo” (anexo IX), por descreverem paisagens do passado e do presente, possibilitaram que 37,5\% (3) dos alunos relacionassem texto e canção com atividades visuais desenvolvidas em sala de aula, como a elaboração de cartazes com gravuras que procuravam representar a letra da canção e a exibição da minissérie "A muralha", lembrada por retratar, segundo os alunos, as origens da cidade de São Paulo. Esse aspecto evidencia, mais uma vez, a importância da relação das linguagens visuais com a linguagem musical. Afinal, como já discutimos no capítulo anterior, qualquer canção forma "paisagens sonoras", o que facilitou a lembrança dos alunos em relação às atividades visuais desenvolvidas no ano anterior.

\section{As representações dos alunos e o processo de formação de uma consciência histórica}

Ao serem entrevistados, os alunos estabeleceram um importante cruzamento entre a linguagem escrita e a musical para o entendimento e a fixação do tema. Não cabe aqui discutirmos se essas representações apresentadas pelos alunos são válidas ou não, do ponto de vista da ciência histórica, mas é inegável a importância da relação do texto escrito com a linguagem musical na formação da chamada consciência histórica. Isso é importante pois os alunos conseguiram estabelecer relação entre um passado recente - composto pelas aulas da professora Marli, o texto do livro didático e a canção na sala de aula, os desenhos, as gravuras e as cenas de uma minissérie - com um presente, que naquele momento da entrevista, um ano mais tarde, foi representado pelo texto-estímulo apresentado pelo entrevistador e as aulas de História na $6^{a}$ série, com outros conteúdos, sem música na sala de aula e com outra professora.

Mas o que é especificamente histórico nas representações dos alunos entrevistados? O histórico é uma orientação temporal que une o passado ao presente de tal forma que confere uma perspectiva futura na realidade atual. Como podemos perceber a partir dos exemplos destacados, as representações dos alunos apresentam uma característica geral da consciência histórica e sua visão na vida prática atual, que serve como um elemento orientador e de identidade, dando a vida prática um marco e uma matriz temporal, uma concepção do "curso do tempo" que flui através dos assuntos mundanos e da vida diária. Essa consciência histórica evidencia um conhecimento histórico que serve, principalmente, para orientar as atividades humanas dos entrevistados evocando a experiência do passado. A consciência histórica forma uma identidade histórica pessoal, em que a personalidade humana expande sua extensão 
temporal além dos limites da própria existência, criando assim uma consciência histórica que pode ser exemplificada pelas representações dos estudantes em relação aos textos, à fala dos professores, às imagens e, principalmente, às canções, pois a linguagem musical forma uma memória musical que, como vimos no capítulo segundo, transforma-se em uma consciência musical.

As representações construídas pelos alunos evidenciam a forma linguística dentro da qual a consciência histórica realiza a função orientadora que é a narrativa, que constitui especificamente a consciência histórica, na medida em que recorre às lembranças para interpretar as experiências do tempo. A lembrança é, para a constituição da consciência histórica, a relação determinante com a experiência do tempo. Algo que fica destacado quando a cidade de São Paulo torna-se objeto histórico de comparação ao longo do tempo, seja por meio da fala da professora, seja pela lembrança em relação à execução da canção.

"O texto fala dos bairros que foram levantados rapidamente em São Paulo no final do século XIX. Eu lembro que ela (professora) passou uma música que falava sobre os bairros, tipo Bom Retiro “ (apêndice VI - quadro 4).

Essa relação com a experiência está na base da distinção entre a narrativa historiográfica e a ficcional. Esse recurso à lembrança deve ser pensado de forma que se trate sempre da experiência do tempo, cuja realidade atual deve não só ser controlada pela ação, mas também ser interpretada mediante a mobilização da lembrança de experiências de mudanças temporais passadas pelos alunos e pela professora e as respectivas trajetórias de vida. O passado é, então, como uma floresta, para dentro da qual esses jovens, pela narrativa histórica, lançam suas indagações, a fim de compreenderem, mediante o que dela ecoa, o que lhes é presente sob a forma de experiência do tempo (mais precisamente: o que mexe com eles) e poderem esperar e projetar um futuro com sentido (RÜSEN, 2001: 62).

Uma segunda especificação da narrativa como fundamento do conhecimento histórico na vida prática fica clara quando se examina mais de perto o processo referido, no qual a memória é propriamente induzida pela narrativa histórica. Nesse ponto, a narrativa passa a constituir a consciência histórica ou conhecimento histórico ao representar as mudanças temporais do passado rememoradas no presente como processos contínuos, nos quais a experiência do tempo presente pode ser inserida interpretativamente e extrapolada em uma perspectiva de futuro. Isso é algo evidenciado em representações comparativas. 
"O texto fala de São Paulo de antigamente e dos seus bairros como Brás, Luz, Barra Funda e o Rio Tietê. Como a música que fala desses bairros atualmente” (apêndice VI quadro 4).

O discurso do aluno revela as mudanças da cidade a partir do presente e possui como referencial a letra da canção sem a interpretação em articulação com os processos temporais rememorados . A narrativa histórica do entrevistado torna presente o passado, de forma que o presente aparece como sua continuação no futuro. Com isso, a expectativa do futuro vinculase diretamente à experiência do passado: a narrativa histórica rememora o passado sempre relacionando-o à experiência do tempo presente e, por essa relação com o presente, articula-se diretamente com as expectativas de futuro, que se formulam a partir das intenções e das diretrizes do agir humano do aluno entrevistado. Essa íntima interdependência de passado, presente e futuro é conhecida como representação da continuidade, serve à orientação da vida humana prática, atual desse aluno (RÜSEN, 2001: 64).

Uma terceira especificação da narrativa como operação intelectual decisiva para a constituição da consciência histórica dá-se quando se pergunta pelos critérios determinantes das representações da continuidade. Tais critérios encontram-se vinculados à constituição de sentido sobre a experiência do tempo mediante a narrativa histórica do entrevistado, pois se trata, afinal, da identidade daquele que tem de produzir esse sentido da narrativa histórica, a fim de poder orientar-se no tempo. Toda narrativa histórica é marcada pela intenção básica do narrador e dos jovens de seu convívio de não se perderem nas mudanças de si mesmo e de seu mundo. A experiência do tempo é sempre da perda iminente da identidade do homem. Portanto, os alunos entrevistados constroem suas representações a partir das interpretações das mudanças temporais em que estão envolvidos, a fim de continuarem seguros de si e de não terem receio de perder-se nelas.

"O texto fala dos índios e da terra que a gente não pode destruir, pois um dia o planeta pode acabar" (apêndice VI - quadro 1).

Trata-se de um esforço de auto-afirmação mediante representações de continuidade, com as quais os jovens relacionam as experiências do tempo com as intenções no tempo: a medida da possibilidade e da consciência dessa relação, ou seja, o critério de sentido para a constituição de representações abrangentes da continuidade é a permanência de si mesmos na evolução do tempo. A narrativa histórica é um meio de constituição da identidade humana e 
desses jovens entrevistados (RÜSEN, 2001: 65-66). Essa competência narrativa sempre está ligada à orientação temporal, dando sentido ao passado mediante a participação de três elementos que se encontram mesclados: forma, conteúdo e função.

Essa tipologia elaborada por RÜSEN (2001) revela e define fundamentalmente os procedimentos da consciência histórica, estabelecendo indicações básicas sobre a "formação histórica" dos alunos. Com essa expressão - "formação histórica" - o autor refere-se a todos os processos de aprendizagem em que a história é o assunto e que não se destinam, em primeiro lugar, à obtenção de competência profissional. Trata-se de um campo a que pertencem inúmeros fenômenos do aprendizado histórico: o ensino de história nas escolas, a influência dos meios de comunicação de massa sobre a consciência histórica e o fator da vida humana prática (família, instituições e colegas), o papel da história na formação dos jovens estudantes como influente sobre a vida cotidiana.

Dessa forma, encontram-se, além dos processos de aprendizagem específicos da ciência da história, todos os demais que servem à orientação da vida prática mediante consciência histórica, nos quais o ensino da história (no sentido mais amplo do termo: como exposição de saber histórico com o objetivo de influenciar terceiros) desempenha algum papel (RÜSEN, 2001: 48). A experiência do passado representa, pois, no relato dos alunos entrevistados, mais que a matéria-prima bruta de histórias produzidas para fazer sentido, mas algo que já possui, em si, a propriedade de estar dotado de sentido, de modo que a constituição consciente de sentido da narrativa histórica se refere diretamente a ela e lhe dá continuação, engendrando vários ingredientes das operações conscientes do pensamento histórico.

O passado passa a ser articulado, como estado de coisas, com as orientações presentes no agir contemporâneo dos alunos. Assim como as determinações de sentido, com as quais o agir humano organiza intenções e expectativas no fluxo do tempo, precisam também apresentarem-se como um fato da experiência atual (RÜSEN, 2001: 73). Portanto, as representações históricas dos alunos têm de ser pensadas como algo que emerge de determinados processos da vida humana prática.

A questão que se coloca nos processos de constituição de sentido pela consciência histórica não diz respeito, sobretudo, ou exclusivamente ao passado, mas à interdependência entre passado, presente e futuro, pois só nessa interdependência os homens conseguem orientar a própria vida, os atos, o tempo. Como representação de ação que se estende pelo passado, presente e futuro, a própria história faz parte dos atos, pois pressupõem um mínimo de orientação temporal, como ficou evidenciado pelas representações elaboradas pelos alunos. 
Trata-se aqui de uma eficácia do passado no presente que não se refere à orientação intencional da vida prática atual.

O passado é eficaz como conjunto silencioso do agir, seja de modo implícito e natural, como, por exemplo, na "vida institucional" representada pela escola, seja nos bastidores dos processos decisórios da "vida cotidiana" (influenciados por colegas, família e meios de comunicação). Nesse momento, a história ainda não é abordada como ciência, mas trata-se de histórias das quais a história nunca chega a romper, pois são pressupostos concretos na vida prática, suas raízes, por assim dizer, na vida humana concreta, com as quais a e a partir das quais se constitui e cresce, seja como processo de aprendizagem, seja como conhecimento científico.

O termo raízes pode ter dois significados: de um lado, as necessidades de orientação percebidas pelos homens, agentes e pacientes, na experiência cotidiana do transcurso do tempo, em si mesmos e em seu mundo. De outro lado, a elaboração de uma determinada ideia de história, correspondente a essas necessidades de orientação que vem influenciar decisivamente a orientação prática da vida, no tempo (RÜSEN, 2001: 22-23).

A consciência histórica é um pré-requisito necessário, pois se trata de uma mediação entre os valores morais (orientadores de comportamento) e a ação dos alunos dentro e fora do ambiente escolar. A maior parte das representações dos jovens entrevistados, durante esta pesquisa, demonstrou a necessidade da consciência histórica para tratarem de valores morais e de argumentação moral (razão) e de como essa consciência pode ser estimulada pela linguagem musical.

O processo de formação das representações históricas dos alunos entrevistados se encontra intimamente ligado aos conceitos cotidianos ou espontâneos, isto é, aos conceitos desenvolvidos no decorrer da atividade prática do aluno, de suas interações sociais imediatas, que se misturam aos conceitos científicos, transmitidos em situações formais de ensinoaprendizagem.

As provas projetivas - pequenos textos didáticos - utilizadas durante as entrevistas acabaram funcionando como fontes históricas, pois os alunos foram capazes de fazer algumas distinções entre os temas. Utilizaram essas fontes como evidências históricas, principalmente quando as relacionavam com a linguagem musical.

A evidência histórica situa-se entre o que o passado deixou para trás, isto é, os textos utilizados nas entrevistas, e o que os alunos reivindicam do passado , ou seja, narrativas ou interpretações históricas estimuladas pela linguagem musical. (ASHBY, 2003: 42). A música, na maioria dos casos, auxiliou os alunos partirem dos questionamentos do presente, 
refazendo, assim, o caminho das interpretações desenvolvidas em torno dos textos, acrescentando outro e retomando, desse modo, o repertório de significados possíveis em torno dos temas históricos propostos pela professora após um ano.

Isso foi possível porque a maioria dos entrevistados soube, mesmo que de forma inconsciente, distinguir entre a natureza intencional de uma fonte e a sua natureza não intencional. O que cada fonte nos quer dizer? O que essa fonte pode dizer-nos, sem que jamais tenha tido a intenção de fazê-lo? Essas são duas questões importantes para levar os alunos a fazerem eficazmente uma aproximação à análise da fonte. É parte importante na construção do conhecimento histórico ser capaz de fazer interferências acerca do passado a partir das fontes, e é preciso que os alunos aprendam, de uma maneira mais racional e menos intuitiva, como fazer questões a uma fonte e responder a elas. (ASHBY, 2003: 50)

O conhecimento histórico só é assimilado pelos alunos quando compreendem os vestígios do passado como evidência no mais profundo sentido, ou seja, como algo que deve ser tratado não como mera informação, mas como algo de onde se possam retirar respostas a questões que nunca se pensou colocar. Esse tipo de investigação aqui empreendido sugere, a partir de algumas representações históricas, que os estudantes construíram ao longo da experiência de vida e motivados pela linguagem musical, lembrança e capacidade de interpretação de textos históricos propostos durante as entrevistas.

Ensinar aos alunos um conceito de evidência como parte da investigação histórica não é tarefa fácil. Contudo, a utilização da linguagem musical pode proporcionar uma abordagem diagnóstica para que a assimilação do conhecimento histórico possa avançar. A música, como no caso da professora, pode trabalhar a partir das compreensões existentes (ideias tácitas) e contestar as ideias que impedem o progresso posterior dos alunos em relação conhecimento histórico, pois a música como um referencial do presente na vida do aluno faz parte da sua consciência histórica, constrói uma ponte entre os conhecimentos prévios dos estudantes e os conteúdos trabalhados pela professora, transformando a assimilação do conhecimento histórico como algo significativo. 


\section{CAPÍTULO 5- O CONHECIMENTO E O SABER-FAZER DO PROFESSOR NA APLICAÇÃO DA LINGUAGEM MUSICAL COMO LEGITIMADORES DE UMA PRÁTICA PEDAGÓGICA NO CAMPO ESCOLAR}

No primeiro dia de trabalho, quando fui apresentado aos alunos, a professora Marli já os havia preparado sobre a minha presença. Houve certa curiosidade, mas nenhuma maior excitação por parte da classe, pois os alunos estavam acostumados com a presença de estagiários. A professora descreveu a sua trajetória docente - vinte e sete anos de profissão, mas apenas o seu terceiro ano naquela unidade escolar (anteriormente havia trabalhado em escolas da zona leste de São Paulo) - e sua prática pedagógica com a utilização da música há mais de vinte anos. Ela também fez questão de ressaltar que procurava acompanhar as turmas até a oitava série para acompanhar-lhes os progressos pedagógico, algo que não era possível naquela escola, porque era a segunda a escolher aulas na atribuição, dependia das escolhas efetuadas pelo outro professor em vias de se aposentar.

Enquanto isso, parte dos alunos fazia uma atividade do livro didático ${ }^{20}$ do texto adaptado de Tucídides "Democracia por um ateniense", enquanto outra prestava atenção na sua explanação. Depois fez questão, junto com a sala, de dar exemplos de como havia trabalhado com os alunos desde o início do ano, retomando o conteúdo ministrado (préhistória brasileira e civilizações hidráulicas: Egito e Mesopotâmia), cantando com os alunos as respectivas canções, situação descrita no início do capítulo terceiro. Depois da demonstração, a docente fez também questão de ressaltar que, na última aula da semana, geralmente às sextas-feiras, sempre levava o aparelho de som portátil da escola para a sala, para que assim os alunos pudessem ouvir os $c d s$ que traziam de suas casas.

A professora também demonstrou orgulho ao falar de seu projeto pedagógico “Cantando a História”, estabelecendo como eixo temático a cidade de São Paulo, projeto desenvolvido nos anos letivos de 2005 e 2006 e que havia sido finalista do " 1 o Prêmio Paulo Freire de Qualidade do Ensino Municipal”. No ano de 2007, também estava concorrendo com outro projeto, cujo título era "Cantando a História pelos caminhos da MPB", apresentando como eixo temático a cultura afro-brasileira. A professora também ressaltou a sua colaboração no "Referencial de expectativas para o desenvolvimento da competência

${ }^{20}$ COTRIM, Gilberto. Saber e fazer a História, 5a Série. $2^{\mathrm{a}}$ ed. São Paulo: Saraiva, 2002. P. 107. 
leitora e escritora no ciclo II do ensino fundamental - História" (2006 e 2007), trabalho coordenado pelas professoras Antonia Terra e Circe Bittencourt, documento que serve como diretriz para os planejamentos dos professores de História do Ensino Fundamental II da rede municipal de ensino da cidade de São Paulo.

\section{O campo escolar e a legitimação da prática pedagógica através da linguagem musical}

Desde a primeira aula, observei que a professora sentiu forte necessidade natural de legitimar, externa e internamente à comunidade escolar, tanto a sua prática pedagógica quanto o seu trabalho com a linguagem musical. Buscava não só ganhar capital cultural e se fortalecer politicamente no campo da escola, pois só estava na escola há dois anos, como também pretendia entrar na esfera acadêmica, já que a partir da sua prática docente objetivava desenvolver um projeto de pós-graduação.

A escola observada e descrita, na concepção de PIERRE BOURDIEU (2001), seria uma forma de campo composto por famílias, alunos, professores, funcionários, direção e supervisão, o que configura um "pequeno mundo" correspondente a um compartimento de um campo maior representado pela Educação do município de São Paulo. Essa instituição forma um espaço de dominação, alianças e conflitos com regras próprias e uma certa autonomia em relação à sociedade, onde os indivíduos agem em função de suas respectivas posições e interesses. Esses indivíduos movimentam-se de acordo com o capital cultural (conhecimentos, desempenhos, diplomas, carreira e educação informal) e o capital social (redes de relações), recursos mais úteis que o capital econômico (condição socioeconômica) no interior do campo formado pela escola ${ }^{21}$.

A escola, enquanto campo, deve ser vista como um espaço de estudo multidimensional de como se elaboram as representações sociais, levando-se em conta a atividade cognitiva pela qual o sujeito constrói sua representação. Deve ainda acentuar aspectos significantes da atividade representativa, tratar da representação como uma forma de discurso, considerar a prática social do sujeito na construção da representação, determinar a dinâmica das representações pelo jogo das relações intergrupais, e identificar o sujeito como

\footnotetext{
21 “Compreender a gênese social de um campo, e apreender aquilo que faz a necessidade específica da crença que o sustenta, do jogo de linguagem que nele se joga, das coisas materiais e simbólicas em jogo que nele se geram, é explicar, tornar necessário, subtrair ao absurdo do arbitrário e do não-motivado os atos dos produtores e as obras por eles produzidas e não, como geralmente se julga, reduzir ou destruir" (BOURDIEU, 2001: 69).
} 
um portador das determinações sociais responsáveis, em última instância, pela produção das representações (SÁ, 2002: 37).

Essas representações sociais produzidas nos campos pelos agentes sociais acabam propiciando a construção das identidades coletivas, pois também é preciso considerar que os indivíduos estão inseridos em determinados espaços, onde se impõe a apreensão diferenciada dos objetos sociais que constituem os diferentes sistemas de referências identitárias, possibilitando uma visibilidade aos diferentes atores sociais. É, portanto, a partir da construção das representações dos diferentes objetos em disputa dentro de um campo particular do espaço social, que um determinado grupo vai construindo os traços distintivos de sua identidade (SOBRINHO, 2000: 120).

A noção de campo forma, em certo sentido, um balizamento para um conjunto de indicações conceituais que possibilitaram a construção do objeto que vai comandar - ou orientar - todas as opções práticas da pesquisa, bem como as análises e interpretações das representações da professora Marli em relação à prática pedagógica. Os pensamentos e experiências que fazem parte de um núcleo central ou estruturante composto pelo campo escola. Esse núcleo central é determinado, de um lado, pela natureza do objeto representado (escola), de outro, pelo tipo de relações que a professora mantém com esse objeto composto por agentes sociais (famílias, alunos, professores, funcionários e direção) enfim, pelo sistema de valores e normas sociais que constituem o próprio campo que BOURDIEU chamara de habitus (ver capítulo 1).

À medida que o campo intelectual e artístico amplia a sua autonomia, representado nesta pesquisa pela escola, elevando-se, ao mesmo tempo, o estatuto social dos produtores de bens simbólicos, os intelectuais e os artistas, aqui representados pelos professores, tendem progressivamente a ingressar, por sua própria conta, e não mais apenas por procuração ou por delegação, reproduzindo o jogo dos conflitos entre as frações dos grupos dominantes que compõem a burocracia da estrutura educacional do município da cidade de São Paulo (BOURDIEU, 2003: 191).

Tais conflitos ficaram mais evidenciados na nona semana de observação, pois antes de subir para a oitava aula de observação, houve um lanche especial oferecido pelas professoras Marli e Suelen (Geografia), como forma de agradecimento, por terem vencido as eleições com a participação de alunos, funcionários e professores dos três períodos, para as funções de orientadoras dos projetos "sala de leitura" e "sala de informática" para o próximo ano letivo. As demais candidatas eram professoras de $1^{\text {a }}$ a $4^{\text {a }}$ da manhã (PI), sendo que uma delas foi apoiada pela professora Cláudia, atual orientadora da "sala de leitura". Durante o lanche 
comemorativo, a orientadora pediu a palavra e prometeu colaborar com a professora Marli, apesar do apoio dado à outra candidata do período matutino, pois acreditava que, por ser um projeto multidisciplinar, a "sala de leitura" deveria ter a orientação de uma professora nível um (PI).

Depois a professora Marli me explicou que a diretora pediu que ela e a professora de Geografia fossem candidatas, pois as mesmas tinham apenas três anos de escola e corriam o risco de não terem aulas naquela unidade escolar no ano de 2008, por que o curso supletivo noturno seria substituído por cursos profissionalizantes. Além disso, segundo a professora, as duas eram reconhecidas pelos colegas e pelos alunos devido aos projetos na escola. No caso da professora Marli, os motivos eram a música e a empatia que causava em seus alunos.

O aumento da autonomia do campo intelectual e artístico representado pela escola em relação às coerções e às demandas diretas das frações dominantes da burocracia educacional, permitiu desenvolver um mercado de bens simbólicos. Isso ampliou a força explicativa das características propriamente intelectuais e pedagógicas da professora como produtora de bens simbólicos, representada pelos projetos e as aulas que envolviam a linguagem musical (BOURDIEU, op. cit: 192). Portanto, esses fatores se encontram associados à ação e à posição que a professora ocupa no campo escolar e na estrutura burocrática dominante do sistema educacional.

\section{O livro didático como a referência pedagógica legitimadora da utilização da linguagem musical}

Os bens simbólicos da professora representados pelos projetos e aulas, apesar da utilização da linguagem musical, têm como principal referência o livro didático. Isso começou a se evidenciar na primeira semana, pois, como já relatei enquanto explicava a organização do seu curso, parte dos alunos fazia uma atividade do livro didático sobre a democracia ateniense. Na segunda semana, a professora apresentou o conteúdo sobre a cidade- Estado de Atenas, discutindo um texto do livro didático 22 "A educação do jovem ateniense". Chamou a atenção para os três princípios básicos da educação ateniense: leitura, ginástica e música, caracterizando e ressaltando a importância da última para os gregos, já que era instrumental, acalmava e harmonizava a vida dos alunos na Grécia Antiga. Após a leitura coletiva (um

${ }^{22}$ COTRIM, Gilberto. Op. cit. Pp. 110-111. 
parágrafo para cada aluno) e as intervenções explicativas da professora, foram destacadas várias palavras do texto para que os alunos fizessem uma pesquisa obrigatória de vocabulário em casa, valendo nota de participação. A professora solicitou uma pesquisa obrigatória sobre a cultura grega antiga e atual em relação à culinária e à música grega, como também sobre a música "Mulheres de Atenas" (1976) e o seu autor Chico Buarque de Holanda (facultativa), para ser inserida na elaboração de vários painéis sobre a cultura grega.

O trabalho dos painéis valeria nota no final do terceiro bimestre e, dependendo da qualidade apresentada, poderia dispensar o aluno da prova. Segundo a professora, a sala de leitura seria o principal espaço para essa pesquisa, pois lá os alunos encontram o livros e revistas para a pesquisa e sua execução em cartolinas, colas, canetas, lápis, folha de almaço, entre outros.

Como podemos perceber, todas as atividades sugeridas pela professora em relação ao conteúdo Grécia Antiga têm como referência o texto do livro didático. Isso foi evidenciado durante a entrevista dela ao falar da construção da sua aula utilizando a linguagem musical e relação desta com outras linguagens (apêndice VIII - tabelas 16 e 17).

- "Trabalho primeiro o conteúdo através do livro didático ou de um eixo temático com textos complementares".

- "Procuro e trabalho canções que se relacionam com o conteúdo".

- "Utilizo imagens do livro didático ou outras imagens para relacionar com a música”.

- ' 'Sempre procuro utilizar uma mesma sequência até a $7^{a}$ série: texto, música, imagens e filme (algumas cenas)”.

O livro didático é um instrumento pedagógico que, nesse caso, serve de referência sobre os conteúdos selecionados da professora. Ao ser utilizado por ela em sua prática docente, o livro possibilitou leituras e contribuiu para a produção de narrativas na busca da compreensão, pelos alunos, dos temas em estudo. Utilizado pelos Propiciou, ainda, como pudemos constatar através das representações dos alunos (capítulo anterior), leituras e diferentes apropriações, que também destacavam a utilização de outras linguagens na sala de aula, como o desenho, o cinema e principalmente a música. A maior parte dos alunos entrevistados não silenciou em suas aprendizagens no ano anterior, pois $75 \%$ conseguiram estabelecer relação com todos os textos da entrevista com os temas que haviam estudado no 
ano anterior (apêndice V - tabela 1), sendo que 50\% conseguiram estabelecer essa relação por meio da linguagem musical (apêndice $\mathrm{V}$ - tabela 2).

A utilização do livro didático também faz parte da representação de um bom professor, que no campo escolar ainda passa pelo ponto de vista da ordenação de sua ação, pois o docente deve desenvolver a prática seguindo uma espécie de "agenda", cujos conteúdos são planos operativos para desenvolver unidades de trabalho (Grécia Antiga), composta de outras unidades mais específicas (cultura e condição feminina) que podem se modelar de forma peculiar através da linguagem pictórica e musical.

Nesse caso, o papel profissional da professora, do ponto de vista didático, se especifica nas tarefas que têm que desenvolver para elaborar e conduzir situações justificáveis a partir de um determinado modelo educativo. Ao decidir sobre as práticas pedagógicas, a docente em questão cumpre duas demandas básicas: escolhe o tratamento de que o currículo de História será objeto em salas de aula e estabelece as regras de jogo para o comportamento dos alunos durante as suas aulas (SACRISTÁN, 2006: 233).

\section{A disciplina como elemento comportamental legitimador da linguagem musical no campo escolar}

Ainda durante a segunda semana de observação, a professora falou, pela primeira vez, sobre a sua preocupação com a disciplina, devido aos problemas ocorridos na aula de outro professor no dia anterior, destacando suas estratégias para minimizar esses problemas, procurando trabalhar com estratégias que aumentassem a auto-estima dos alunos, discussão de textos e filmes fora da sala de aula que fizessem o aluno refletir sobre a sua prática e a sua importância dentro da escola. Apesar de não ter acompanhado nenhum desses momentos mais pontuais, notei durante as minhas observações uma preocupação constante da professora com a disciplina da sala, procurando ressaltar para a sala que a boa postura dos alunos contribuiria para o bom andamento da aula. A docente chamava constantemente a atenção daqueles alunos que começavam a atrapalhar as atividades desenvolvidas.

Na terceira semana, como já foi descrito no capítulo três, quando observei os alunos fazendo uma atividade individual em relação à canção "Mulheres de Atenas", na qual deveriam retratar uma parte da mesma por meio de um desenho e colocar uma legenda, ficou evidente a preocupação da professora em fotografar os alunos trabalhando em sala de aula. Nesse caso, o registro fotográfico da atividade pedagógica da professora era, ao mesmo 
tempo, uma forma de documentar, divulgar e legitimar a prática educacional dentro e fora da escola.

Após os registros fotográficos, a docente passou a vistar as atividades relacionadas ao tema Grécia Antiga n o caderno dos alunos. Enquanto observava os cadernos, o que fazia em frequência quinzenal, a professora escrevia bilhetinhos elogiosos para os pais daqueles alunos que tinham o caderno em dia, nomeando em voz alta os que melhoraram a postura e a organização em relação ao caderno e o cumprimento das tarefas propostas durante as duas últimas semanas. Segundo a professora, isso era uma das estratégias para aumentar a autoestima dos alunos mais indisciplinados ou com problemas de aproveitamento da sala.

Após o sinal, durante a quinta visita, subimos para a quinta aula de observação, iniciada de forma expositiva sobre a cidade- Estado de Esparta e a educação voltada para o militarismo. Essa aula era baseada no texto do livro didático ${ }^{23}$ com leitura posterior dos alunos que se ofereciam para ler os parágrafos com a professora escolhendo o leitor da vez. A leitura era entremeada com intervenções explicativas da professora, o que acabou levando a uma discussão sobre a seguinte questão: qual seria o melhor sistema educacional? A maior parte dos comentários dos alunos referia-se de um sistema rigoroso, tanto em termos de avaliação, como também em termos disciplinares. Para eles, qualquer tipo de desobediência deveria levar o estudante a receber severas sanções. Esse tipo de resposta levou a professora a comentar comigo, como os alunos são rigorosos consigo mesmos e como eles sugeriam, nas próprias falas, o estabelecimento de limites.

Antes de terminar a aula, a professora devolveu a avaliação dissertativa sobre a canção "Mulheres de Atenas", cujo rendimento foi considerado por ela plenamente satisfatório. Após a aula, já na sala dos professores, a professora acabou discutindo com o professor Jonas de Geografia, um dos mais velhos da escola, sobre a validade ou não de se trabalhar com alunos de inclusão, devido a alguns problemas disciplinares ocorridos na $5^{\mathrm{a}} \mathrm{B}$ durante as aulas dele e de outros colegas e que haveria alguns desses alunos envolvidos. Eram no total três meninos que inicialmente não foram identificados durante as primeiras observações. A professora defendeu essa prática pedagógica, pois antes tais alunos eram marginalizados e não tinham nenhuma oportunidade de progredir e até de se recuperar, pois para ela os problemas disciplinares da classe não eram culpa exclusiva deles e que os problemas de indisciplina que ocorriam na sala ela conseguia resolver com a prática pedagógica motivadora e, com isso,

${ }^{23}$ COTRIM, Gilberto. Op. cit. Pp. 112-113. 
buscava melhorar a auto-estima do aluno, sem, no entanto, citar a música como parte dessa estratégia.

Como podemos notar, durante os episódios descritos anteriormente, os temas comportamento e disciplina dos alunos trazem uma forte representação da prática pedagógica da professora, auxiliada pela linguagem musical como facilitadora das funções básicas que a instituição escolar tem, atribuídas pela sociedade: instruir, manter um ambiente de trabalho, controlar a conduta do aluno dentro de determinados moldes de comportamento, colaborar em suma, na socialização dos alunos dentro de uma cultura, de certos valores, de certos padrões de conduta social dentro e fora da escola (SACRISTÁN, op. cit.). Portanto, a representação da competência da professora não está apenas em planejar estratégias e tarefas próprias, permeadas pela linguagem musical, reconhecidas pela comunidade escolar; mas também tem a ver muito mais com a capacidade dela para prever, reagir e dar soluções às situações pelas quais transcorrem o seu saber e fazer profissionais num campo institucionalizado representado pela escola.

\section{A importância do conhecimento e do saber-fazer do professor na aplicação da linguagem musical}

A professora como sujeito histórico-social firmada no âmbito de uma prática determinada, como já disse, acaba produzindo um saber que lhe sustenta a representação histórica e a utilização da linguagem musical como mediação pedagógica em relação aos alunos. O saber do docente, se analisado nos aspectos individuais e sociais, permite que se lhe capte a natureza social e individual como um todo. Para isso é necessário que o saber do professor seja compreendido em íntima relação com o seu trabalho na escola e na sala de aula. Isso significa dizer que as relações dos professores não são apenas cognitivas, mas mediadas pelo trabalho que lhes fornece princípios para enfrentar, como discutimos anteriormente, e solucionar situações cotidianas (TARDIF, 2006: 16-17).

Outro ponto importante é a ideia de diversidade, também identificada como pluralismo do docente, pois o professor se refere a conhecimentos e a um saber-fazer pessoal, que falam dos saberes curriculares, dos programas e dos livros didáticos, bem como se apoiam em conhecimentos disciplinares relativos às matérias ensinadas, moldam-se em sua própria experiência que também aponta à própria formação profissional (TARDIF, 2006: 18). Em suma, o saber do professor é plural, utilizado de vários modos e heterogêneo, porque acaba envolvendo, no próprio exercício do seu trabalho, conhecimentos e um saber-fazer bastante 
diverso, provenientes de fontes variadas e de naturezas diferentes, que, no caso desta pesquisa, como estamos constatando, encontram-se ligados à utilização da linguagem musical nas aulas de História. Algo que pode ser constatado quando a professora foi questionada pela aplicação da linguagem musical na época de faculdade e no início da carreira de magistério

A aplicação da linguagem musical na época da faculdade e no início da carreira do magistério (apêndice VIII - tabela 15)

- "Na época de faculdade não pensava em utilizar música em sala de aula”.

- “Isso ocorreu na prática, quando ainda era professora P2 (professora eventual), substituindo outros professores".

As duas falas anteriores revelam que os saberes docentes são temporais. Quando na fase de formação inicial, a professora vive um momento estratégico em sua vida profissional, isto é, vivencia um típico ritual de passagem. Ela é, ao mesmo tempo, aluno e professor, pois tem a sensibilidade aguçada para perceber as repercussões da ação educativa com olhos de quem ainda se sente como aluno. (MONTEIRO, 2001:141).

Já a professora em plena ação, com os alunos na sala de aula, elabora estratégias e esquemas cognitivos, simbólicos. Esses elementos a ajudam a transformar a matéria em função de condicionantes como: tempo; programa; o projeto pedagógico da escola; a velocidade de assimilação dos alunos; limites impostos pela avaliação; motivação dos alunos... É verdade que o conhecimento pedagógico do conteúdo a ser ensinado não pode ser separado do conhecimento desse conteúdo. Entretanto, conhecer bem a matéria que se deve ensinar é apenas uma condição necessária - e não uma condição suficiente - do trabalho pedagógico. Em outras palavras, o conteúdo ensinado em sala de aula nunca é transmitido simplesmente tal e qual: é selecionado, adaptado, transformado e apresentado para um público em função da compreensão do grupo de alunos e dos indivíduos que o compõem. Algo destacado pela professora durante as entrevistas quando relatou alguns exemplos da relação entre música e conteúdo. 
- "Da $5^{a}$ série até a $7^{a}$ série procuro partir do conteúdo para a música".

- "Na $5^{a}$ série procuro trazer canções, cuja temática esteja mais explícita".

- "A partir da $7^{a}$ série peço para os alunos pesquisarem e trazerem músicas relacionadas ao tema alunos para serem comparadas ao repertório da professora".

Ao identificarmos a pedagogia e o ensino à tecnologia do trabalho docente, falamos de uma "arte de ensinar". Essa definição tem o mérito de tomar possível a constituição de um repertório de conhecimentos pedagógicos próprios à profissão. Trata-se de uma arte que se faz presente apenas quando as técnicas de base do trabalho são assimiladas e dominadas. Um professor perito é semelhante a um músico ou a um ator que improvisa: cria coisas novas a partir de rotinas e de maneiras de proceder já estabelecidas (TARDIF, op. cit.: 121). Como, por exemplo, a professora, na última aula da semana, geralmente às sextas-feiras, levava o aparelho de som portátil da escola para a sala, para que assim os alunos pudessem ouvir os cds que traziam de suas casas, compondo a paisagem sonora para as atividades pedagógicas na sala de aula (ver capítulo terceiro).

A ação profissional da professora é estruturada por duas séries de condicionantes: os ligados à transmissão da matéria (condicionantes de tempo, de organização sequencial dos conteúdos, das mediações utilizadas - como no caso da música -, de alcance de finalidades, de aprendizagem por parte dos alunos, de avaliação, etc.) e os ligados à gestão das interações com os alunos (manutenção da disciplina, gestão das ações desencadeadas pelos alunos, motivação da turma, etc.). Portanto, o trabalho docente no ambiente escolar consiste em fazer essas duas séries de condicionantes convergirem, em fazê-las colaborar entre si. 


\section{CAPÍtUlo 6- A MEMÓRIA E A CONSCIÊNCIA HISTÓRICA DO SABER-FAZER DO PROFESSOR NA APLICAÇÃO DA LINGUAGEM MUSICAL}

Como vimos no capítulo anterior, os condicionantes que fazem parte dos saberes formados pela ação da professora Marli têm um caráter temporal que engloba a história de vida e a carreira profissional que formam uma memória e uma consciência musical e histórica. Ao longo da observação e também através das repostas obtidas durante a entrevista, notei que a prática pedagógica com a utilização da linguagem musical encontra-se ligada a um saber-fazer da professora que é construído ao longo da sua trajetória de vida social e profissional.

A análise do discurso da professora evidencia algumas linhas de força dos seus percursos profissionais: as expectativas pessoais e familiares que se cruzam com as oportunidades e os constrangimentos institucionais e sociais, quando se opta pela profissão; a tensão que acompanha as primeiras experiências profissionais, os sentimentos que então se vivem e como contribuem para modelar a identidade profissional; o desenvolvimento de diferentes linhas estruturantes do progressivo amadurecimento profissional evidenciadas nas relações com os alunos, com os colegas, com o conhecimento e com a própria profissão; as dificuldades que se associam à articulação, ao longo dos anos, da esfera familiar e profissional; as mudanças de expectativas decorrentes de alterações institucionais, jogando em sentidos opostos, e os seus efeitos nas atitudes e nas disposições para maior ou menor investimento pessoal (CAVACO, 1999: 178).

O ambiente sociocultural e as experiências de vida dos professores durante a infância e adolescência devem ser destacados (apêndice VIII - quadro 11), pois se trata de algo que se transforma em uma referência do estilo de vida do professor dentro e fora da sala de aula, influenciando sobre os modelos de ensino e sobre a prática educativa. Isso fica evidenciado, por exemplo, quando a professora Marli fala sobre as outras músicas que poderiam ser utilizadas nas aulas da $5^{\mathrm{a}}$ série e cita “'Tribos dos Carajás' de Martinho da Vila (apêndice VIII - quadro 19), canção que ouvia em uma vitrola na casa da avó materna, onde os encontros familiares acabavam em bailes.

Outra característica comum do ambiente sociocultural dos professores e sempre identificado nas narrativas professores é o aparecimento de um professor preferido que 
influenciou os alunos de modo significativo. No caso da professora, enquanto jovem aluna, fala das músicas cantadas em datas comemorativas nos anos 70, de uma professora de inglês e das letras utilizadas nas aulas de Português sem a música, como algo que despertou o interesse pela utilização da linguagem musical no magistério (apêndice VIII - quadro 12). Em conclusão, tais momentos e pessoas fornecem um "modelo funcional" e, além disso, influenciaram provavelmente a visão subsequente da pedagogia desejável, e bem assim, possivelmente, a escolha do próprio curso, em termos de matéria de ensino e a prática pedagógica a ser seguida.

A escolha da profissão e a trajetória de trabalho da professora resultam, conforme constatei, de múltiplos fatores: implicam redes de relações sociais e culturais tecidas em diversos níveis e atravessadas por lógicas próprias, feitas de acasos e circunstâncias, de aspirações e de constrangimentos, de coincidências e de decisões. Determinante é ainda o campo profissional, que, com estrutura linear sequencial se articula com a necessidade orgânica e social de desenvolvimento e de afirmação pessoal, condicionando representações, horizontes de sentido e aspirações. Contendo ou estimulando, facilitando ou inibindo, as estruturas profissionais interagem com as trajetórias pessoais, dando-lhes contornos gerais que só se compreendem no quadro de processos coletivos. (CAVACO, op. cit.: 179).

\section{A identidade e o saber-fazer da professora ligada à dimensão temporal da carreira profissional}

Para compreendermos a questão da identidade da professora, temos que inseri-la imediatamente na história dos próprios atores que fazem parte da sua trajetória,de ações, projetos e desenvolvimento profissional. Minhas análises indicam que a socialização e a carreira dos professores não são somente o desenrolar de uma série de acontecimentos objetivos. Ao contrário, a trajetória social e a profissional ocasionam custos existenciais (formação profissional, inserção na profissão, choque com a realidade, aprendizagem na prática, descoberta dos próprios limites, negociação com os outros, etc.) e é graças aos recursos pessoais que podem encarar esses custos e assumi-los. Ora, é claro que esse processo modela a identidade pessoal e profissional dela, e é vivendo-o por dentro, por assim dizer, que pode tomar-se professora e considerar-se como tal aos seus próprios olhos (TARDIF, 2006: 107).

A identidade profissional da professora não é um dado adquirido, não é uma propriedade, não é um produto. A identidade, como já expus no capítulo anterior, é um lugar 
de lutas e de conflitos, um espaço de construção de maneiras de ser e de estar na profissão. Por isso, é mais adequado falar em processo identitário, realçando uma mistura dinâmica que caracteriza a maneira como ela se sente e se diz professora.

A construção de identidades passa sempre por um processo complexo pelo qual cada profissional se apropria do sentido da sua história pessoal e profissional. É um processo que necessita de tempo. Um tempo para construir e refazer identidades, para acomodar inovações, para assimilar mudanças. Esse processo identitário passa também pela capacidade de a professora exercer, com relativa autonomia, a sua atividade, pelo sentimento como ela controla o trabalho. A maneira como ela ensina está diretamente dependente daquilo que ela é como pessoa quando exerce o ensino. Portanto, é impossível separar o eu profissional do eu pessoal da professora (NÓVOA, 1999: 16-17).

Esse processo identitário faz parte de uma historicidade que auxilia na construção da consciência musical e histórica da professora, expressa-se e se imprime nos saberes profissionais, e mais especificamente nos saberes experienciais adquiridos no início da carreira, que são, parcialmente, não só uma reativação, mas também uma transformação dos saberes adquiridos nos processos anteriores de socialização (familiar, escolar e universitária), que destaquei no início do capítulo.

A dimensão temporal do trabalho, isto é, a experiência da prática da profissão numa carreira, é crucial na aquisição do sentimento de competência e na implantação das rotinas de trabalho. Noutras palavras, é fundamental na estruturação da prática da linguagem musical na sala de aula. Muitas vezes, devido à necessidade de sobrevivência profissional, o professor deve mostrar do que é capaz. Isso leva à construção dos saberes experienciais que se transformam, muito cedo, em certezas profissionais, truques do ofício, rotinas, modelos de gestão da classe e de transmissão da matéria. Esses repertórios de competências constituem o alicerce sobre o qual vão ser edificados os saberes profissionais durante o resto da carreira.

Todavia, tais saberes não se limitam de modo algum a um domínio cognitivo e instrumental do trabalho docente. Abrangem igualmente aspectos como o bem-estar pessoal em trabalhar nessa profissão, a segurança emocional adquirida em relação aos alunos, o sentimento de estar no seu lugar, a confiança nas capacidades de enfrentar problemas e de poder resolvê-los (alunos difíceis, conflitos, etc.), o estabelecimento de relações positivas com os colegas e a direção... Algo diversas vezes relatado durante as nossas observações.

Em outras palavras, se é verdade que a experiência do trabalho docente exige um domínio cognitivo e instrumental da função, também exige socialização na profissão e uma vivência profissional através das quais a identidade profissional vai sendo paulatinamente 
construída e experimentada. Nesse caso, entram em jogo elementos emocionais, relacionais e simbólicos que permitem que um indivíduo se considere um professor, viva como ele e assuma, assim, subjetiva e objetivamente, o fato de seguir carreira no magistério.

O tempo não é somente um meio no qual se encontram mergulhados o trabalho, o trabalhador e seus saberes; também não é unicamente um dado objetivo caracterizado, por exemplo, pela duração administrativa das horas ou dos anos de trabalho. É também um dado subjetivo, no sentido de que contribui poderosamente para modelar a identidade do trabalhador. É apenas no fim de certo tempo da vida profissional - , tempo da carreira - que o $e u$ pessoal vai-se transformando pouco a pouco, em contato com o universo do trabalho, e se toma um eu profissional (TARDIF , 2006: 108). Isso se evidencia quando a professora fala sobre a aplicação da linguagem musical na época de faculdade e no início da carreira do magistério (apêndice VIII - quadro 15).

A noção de experiência que está no centro da representação do Eu profissional dos professores passa obrigatoriamente pelo saber ensinar. Remete ao tempo concebido como um processo de aquisição de um certo domínio do trabalho e de um certo conhecimento de si mesmo e da cultura escolar (apêndice VIII - qaudro 24), que envolve o seu trabalho.

A iniciação profissional como professor decorre, na maioria das vezes, em condições de profunda insatisfação em relação a necessidades como: segurança; integração no trabalho; respeito por si; e prestígio do estatuto. Muitas vezes, a preferência que os alunos manifestam pelos professores jovens permite que, em muitos casos, se estabeleçam relações próximas, quase fraternais, que justifiquem e frequentemente permaneçam, desse período de trabalho, recordações de uma vivência afetiva muito gratificante, que serve como incentivo para o aperfeiçoamento de uma prática pedagógica. O reflexo da vivência desse período inicial fica evidente quando a professora fala da importância da música nas suas aulas para os ex-alunos através de contatos em uma rede social na Internet ${ }^{24}$.

\section{A importância da música nas aulas de História para os ex-alunos (apêndice VIII - tabela 21)}

- "Porque eles lembram das aulas através das músicas e dos intérpretes".

- "Lembram das atividades ligadas à música, principalmente dos desenhos".

\footnotetext{
${ }^{24}$ http://www.orkut.com.br/Main\#Community?cmm=100680424. Acesso em 22/06/2009.
} 
O sentido social encontrado na profissão pode também contribuir para atenuar o choque entre as expectativas de uma identidade profissional preestabelecida e as condições reais de trabalho, ajudando a questioná-las com pertinência e a resolver as dificuldades mantendo o docente, em si mesmo, uma confiança suficientemente grande para considerar qualquer experiência vivida como importante desde que, a partir dela, se aprenda e se cresça como indivíduo, fazendo-se e definindo-se. Isso fica evidente quando a professora descreve no seu livro a própria experiência inicial com a linguagem musical em sala de aula.

"Tudo começou, em 1980, quando ainda universitária, Ingressei no Magistério, lecionando em uma Escola Estadual na periferia da cidade de São Paulo. (...). Eu percebia que a análise de letras da MPB em sala de aula despertava em meus alunos simpatia e curiosidade pela minha disciplina e as aulas de História ficavam mais interessantes. (...), levava essas letras para a sala de aula e as analisava dentro do contexto histórico- socialbrasileiro. Eu era, então, a professora que andava com a 'vitrolinha' da escola para cima e para baixo, pois, o próximo passo era levar os discos para a classe cantar as músicas com meus alunos em sala de aula” (CARVALHO, Marli Oliveira de. Op. cit. Pp. 14-15.)

\section{A procura da realização no presente}

Segundo algumas pesquisas, já desde o início da carreira, é possível distinguir duas linhas orientadoras do sentido dado à profissão do magistério. Essas linhas parecem aprofundar-se e distanciar-se significativamente, por volta da crise da meia idade.

A primeira se caracterizaria pela valorização dos aspectos burocráticos, pelo sentido de continuidade e de aceitação resignada das disposições hierárquicas; manifesta-se pelo isolamento na ação pedagógica, pois conduz ao fechamento em relação às mudanças; há ceticismo, ressentimento em relação aos outros, amargura em relação à profissão, crença em determinismos cegos no desenvolver das situações. A segunda encontra sentido na inovação, no acolher da diversidade, alicerça-se na partilha, nas experiências e no trabalho, no questionamento das situações; caracteriza-se pela capacidade de contextualizar os acontecimentos e os fatos, de perceber os olhares dos outros, pela vontade de intervir nos processos, pela persistência na apropriação de conhecimentos favoráveis ao desenvolvimento profissional (CAVACO, op. cit.: 189).

No caso da professora, observei que a segunda linha torna-se cada vez mais predominante. Porque o progressivo domínio das estruturas de trabalho, a segurança 
decorrente da estabilidade no emprego e da permanência numa mesma escola, facilitou, numa segunda fase da carreira, a transferência das preocupações dominantes para as tarefas pedagógicas centradas, principalmente, nos alunos.

O “aprender” História através da linguagem musical (apêndice VIII - quadro 20)

- "Porque os alunos gostam de cantar, fazendo da música um elemento motivador para eles aprenderem História"

- "A música facilita a memorização e a motivação para o entendimento do conteúdo".

- "Altera a visão que os alunos têm sobre um determinado tema histórico".

- "A troca de repertórios provoca uma aproximação entre professor e alunos, facilitando a mediação".

A linguagem musical passa a fazer parte do núcleo central das suas indagações. Assim, a questão que a professora se coloca é: Como se deve ser para os alunos conseguirem $(\ldots)$ ?

Como em outras profissões, os professores do grupo etário acima dos trinta anos como no caso da professora, parecem viver um fenômeno de apropriação das múltiplas dimensões do trabalho e das suas regras, procuram descobrir e experimentar as competências, redimensionam as aspirações, comportam-se de maneira a afirmar-se, a fazer reconhecer a identidade profissional (CAVACO, op. cit.: 180). No caso da nossa docente, passa obrigatoriamente pelo trabalho com a linguagem musical na sala de aula.

$\mathrm{Na}$ fase atual, sente-se já o tempo correr e, se na fase anterior era dominante a preocupação pelo futuro a construir, agora é a forma de ocupar plenamente o presente que mais importa. Se ontem se refletiam as finalidades do trabalho, neste período a professora pensa mais nas modalidades de ação e reflexão sobre a sua prática pedagógica. Modalidades destacadas pela professora quando fala da utilização esporádica da música na sala de aula por outros professores. 
A utilização esporádica da música na sala de aula pelos professores (apêndice VIII - quadro 22)

- "Eles gostam, mas não sabem como utilizar, evidenciando uma falta de criatividade”.

- "O medo dos professores da música ser considerada chata pelos alunos”.

- "Alguns trabalham a letra sem a música”.

- “A linguagem musical já se encontra incorporada a minha prática docente, enquanto para outros é novidade”.

Essas ideias sobre a ação pedagógica, também aparecem quando ela destaca a relação entre a música e as demais linguagens na sala de aula (anexo VII - tabela 23).

A relação entre a música e as demais linguagens na sala de aula (apêndice VIII - tabela 23)

- “As linguagens devem ser utilizadas como suporte para o conteúdo e as aulas expositivas”.

- “As mediações entre as linguagens e destas com os conteúdos devem ser feitas através do professor".

Preocupações que se mantêm quando a professora estabelece algumas reflexões sobre a música e a cultura escolar.

A música e a cultura escolar (apêndice VIII - tabela 24)

- “A música ainda é vista como barulho na escola, o que, algumas vezes, motiva reclamações dos outros professores”.

- “A cultura escolar ainda é vista como a cultura do silêncio, o professor e a sua aula expositiva com os alunos escutando sentados em silêncio”.

- "Na escola continua a rádio e a escuta individualizada (mp3, mp4 e celulares)”.

- “A rádio serve para socializar os gostos dos alunos, às vezes peço para eles levarem as suas musicas para a sala de aula”.

- $\quad$ "Às vezes eles levam musicas que se referem às musicas e aos artistas trabalhados em sala de aula, que muitas vezes eles escutam e baixam do computador, com o mp3 não existe mais a cultura do disco".

- $\quad$ "As músicas que os alunos trazem não têm quase letra e sim ritmos e batidas eletrônicas que vêm do funk".

- 'O coordenador Cláudio saiu da escola no ano passado (2008) e o projeto da 'aula pública', que foi trazido por mim e ampliado pelo coordenador em 2007 terminou."

- “Com o fim do projeto a 'aula pública' permaneceu como uma ação isolada, quando apresento as músicas com os alunos no pátio, nos vinte minutos finais da ultima aula, em uma data prédeterminada pela direção da escola". 
Com o discurso reflexivo sobre a ação pedagógica, a professora revela sentimentos de autonomia, ambição, segurança, competência, expansão e extroversão, que marcam as relações do indivíduo consigo mesmo, com os outros e com a profissão. A docente em questão vive com grande envolvimento este período da sua existência, mas o sentido dos caminhos que percorre pode ser diferente. Tenta ocupar plenamente o espaço de trabalho e, ao se encontrarem vias de aprofundamento da profissão - na gestão da escola, em tarefas de formação pedagógica, através da colaboração em experiências inovadoras - a professora procura desenvolver um trabalho intenso, diversificado e enriquecedor de forma gratificante pela retribuição afetiva e pelo significado social encontrado.

Tentar diversificar o trabalho, procurar dimensões mais criativas e enriquecedoras para a atividade cotidiana, talvez contribuir para recompor a imagem diminuída da profissão, mostrar o seu trabalho além dos muros da escola são os objetivos confessados. Isso fica evidenciado na fala da professora quando ela destaca os resultados profissionais com a sua prática pedagógica, o que também reafirma as modalidades de ação e reflexão destacadas anteriormente.

Os resultados profissionais da professora com a sua prática pedagógica (apêndice VIII - quadro 25)

- "A maioria dos professores acredita que o sucesso de uma prática pedagógica deva se restringir a sala de aula e não há preocupação em socializá-la".

- "A minha metodologia é baseada apenas na intuição e na emoção que provoca nos alunos".

O mesmo rigor afirmativo que se manifesta em procurar, longe da escola, corresponder a uma necessidade de realização criativa e enriquecedora, ou a descobrir no espaço escolar áreas de expansão e desenvolvimento, pressente-se nas críticas às estruturas mestras do sistema de ensino. Assim, alguns professores, tendo eles mesmos passado por uma experiência de aprendizagem participada e ativa nos cursos de graduação, pós-graduação ou aperfeiçoamento, sentem-se seguros para fazer críticas, ou comparações, que rompem o discurso comedido, aparentemente consensual, que funciona na escola. 
- "A música ainda é vista como barulho na escola, o que, algumas vezes, motiva reclamações dos outros professores".

- "A cultura escolar ainda é vista como a cultura do silêncio, o professor e a sua aula expositiva com os alunos escutando sentados em silêncio".

- "No conteúdo eu não posso intervir, mas a minha metodologia encontra-se incorporada na legislação, escutar música na sala de aula não é mais uma pratica marginal, quando o diretor ainda mandava desligar o rádio".

Nesse caso, a professora vive no cotidiano de trabalho as contradições do presente, porém muitas vezes não tem espaço para esclarecer nem oportunidade de aprofundar; atormentam-na inquietações que não partilha porque tem medo de perder a face, de fragilizar a imagem de sucesso que procura compor. O ofício de professor conduz a pessoa, o profissional, a comprometer-se com um discurso que celebra os valores da democratização, da cooperação e da solidariedade, mas exige-lhe também que atue hierarquizando, selecionando, impondo a concorrência e a competição. É nesse contexto social, cruzado com o mundo profissional, que, no nosso estudo, procuramos situar essa professora do ensino fundamental, considerando que aquilo que diz e faz é mediado pelo corpo, por afetos, sonhos, fantasmas e convicções que a acompanham.

A identidade profissional construída em interação com o universo de trabalho, modelada por representações que o estruturam, mantém um núcleo genético central que o mundo da vida contribui para enriquecer e afeiçoar. Inscrevem-se ainda no ofício de professor a maneira pessoal de ele encarar, no seu campo, a atuação dos múltiplos fatores sociais e institucionais que, interatuando, orientam-lhe o percurso profissional.

Esses processos vividos não o são sempre com lucidez e plena consciência: as forças auto-organizadoras têm, por vezes, caráter instintivo que se concretiza por meio de uma prática pedagógica. No caso da professora que observei nesta pesquisa, esses processos têm vários nomes, que também já foram constatados em outras pesquisas: reforço de autonomia pessoal; afirmação pessoal e social; apropriação de um maior poder pessoal em relação a si própria e ao meio envolvente; capacidade de gestão de circunstância e contextos complexos e contraditórios; recriação das suas energias através de um agir dos seus valores (MOITA, 1999: 138).

A profissão é um espaço de vida atravessado por processos de formação que, aparentemente, nada têm a ver com o mundo intraprofissional. Todos os passos de vida são 
influenciados pelas energias formadoras que se desenvolvem no interior do espaço profissional. A palavra repercussão parece ajustar-se para nomear essa realidade. Um processo de formação, mesmo quando está mais ligado explicitamente a um domínio da vida, tem repercussões em todos os outros domínios (MOITA, op.cit.)

Na história de vida da professora, encontrei uma maneira única de gerir e organizar as energias interiores e exteriores. Nesta história de formação, identifiquei processos parciais, grandes linhas de força de um processo mais global. Esses processos parciais não são linhas paralelas, mas reforçam-se e integram-se. Por vezes começam como reações a circunstâncias provocadoras, ou são desencadeados por crises e situações dissonantes vividos em vias labirínticas, que não são vividos como rupturas com o passado, mas como novas aberturas que encadeiam as dimensões temporais que formam uma consciência musical e histórica que chegam à sala de aula.

\section{A interação entre a identidade pessoal e a identidade profissional na construção da consciência musical e histórica}

A influência dos outros espaços de vida em relação à profissão é muito diversificada. Os outros espaços de vida, nomeadamente o espaço familiar e o social, podem ser um limite, um paradigma, ou apenas um acessório em relação à vida profissional. Mas se essas influências podem ter um caráter dominante, pelo menos em certas etapas da vida, apesar de não serem exclusivos e nem possuírem um caráter unidimensional.

Dentro dessa perspectiva diacrônica, pode-se notar uma influência muito forte de um tempo "passado" na vida profissional - o tempo de infância e da adolescência. As experiências feitas durante essas fases da vida projetam-se na relação com os alunos. É significativo ouvir a professora explicitar as marcas das próprias experiências de criança e adolescência nas suas relações educativas. Essas explicitações acabam esclarecendo certas opções para os percursos profissionais e suas práticas pedagógicas.

Influência musical na infância e adolescência (apêndice VIII - quadro 11)

\begin{tabular}{|c|}
\hline Cresceu ouvindo o rádio e cantando o repertório da jovem guarda \\
\hline O pai ouvia Adoniran Barbosa interpretado pelos Demônios da Garoa (trabalhou em sala de aula) \\
\hline A mãe ouvia Nelson Gonçalves \\
\hline Na casa da avó materna havia uma vitrola onde os encontros familiares acabavam em bailes (Luiz Gonzaga, \\
Clara Nunes e Martinho da Vila - já trabalhou uma canção deste último em sala de aula)
\end{tabular}




\begin{tabular}{|c|}
\hline Programa de rádio "Barros de Alencar" ( "música brega ") \\
\hline Nos anos 70: Raul Seixas, Rita Lee e Secos \& Molhados (maior influência da televisão) \\
\hline Rádio Difusora AM (final dos anos 70) e Radio Cidade FM (início dos anos 80) \\
\hline
\end{tabular}

Influência musical na escola (apêndice VIII - quadro 12)

\begin{tabular}{|c|}
\hline Músicas cantadas em datas comemorativas (anos 70) \\
\hline Aulas de Inglês: The Platers, Elvis Presley e Frank Sinatra \\
\hline Letras utilizadas nas aulas de Português sem a música (ginásio e colegial) \\
\hline
\end{tabular}

Constata-se a presença ativa, na vida profissional, dos valores que tiveram raízes na esfera familiar. Citam-se exemplos: nas músicas de Adoniran Barbosa e Martinho da Vila que já foram utilizadas em sala de aula, na educação formal, quando a professora destaca as letras utilizadas nas aulas de Português durante o ensino básico (apêndice VIII - quadros 11 e 12).

A reflexão sobre como se processa o diálogo ou o conflito entre as várias ordens de valores que atravessam a vida de uma pessoa pode ser reveladora. O papel da profissão em relação aos outros espaços de vida pode ter múltiplos aspectos, entre os quais, um caráter compensatório ou equilibrante. Pode também ser um recurso ou ter um lugar central na vida e vir mesmo a ser o seu "motor". A profissão é, por vezes, um meio de afirmação pessoal e social, sobretudo quando o mundo da família e da casa é sentido como demasiado apertado. As mulheres sentem que há frequentemente uma rivalidade entre o seu espaço familiar e o seu espaço profissional (MOITA, op.cit.: 139).

Para a professora, a profissão é a mediação que lhe permite uma intervenção no espaço social na dimensão macro. Vê na profissão um meio privilegiado de contribuição no sentido da mudança e, por isso, empenha-se nela fortemente. A profissão, em relação à professora, é um projeto que integra outro mais vasto. Nesse caso, é vivida de modo extremamente mobilizador, como fica evidenciado quando a professora fala sobre os resultados profissionais com a sua prática pedagógica (apêndice VIII - quadro 25). Algo também destacado no final do seu livro:

“o sucesso do trabalho foi verificado por meio de uma maior participação e interesse de meus alunos nas aulas de História nas escolas por onde trabalhei no decorrer de minha 
trajetória docente. (...) Estes educandos, quando questionados quanto à sua opinião sobre as aulas de História com música, afirmavam que 'a aula fica muito mais alegre e muito mais fácil', ou então, que consideraram a disciplina 'muito legal', pois a gente aprende e se diverte ao mesmo tempo", já outros alunos comentaram que, ao estudar o cancioneiro popular, "nós conhecemos a história dos nossos antigos cantores'" (CARVALHO, Marli Oliveira de. Op. cit. Pp. 38.).

Notamos uma grande variedade de relações que se estabelecem entre a identidade pessoal e a identidade profissional. Há nessas relações uma atividade de autocriação e de transformação vividas entre a tensão e a harmonia; a distância e a proximidade; a integração e a desintegração. A professora, nesse caso, é o elemento central, procurando a unificação possível e sendo atravessada por múltiplas contradições e ambiguidades que auxiliaram na construção da sua consciência musical e histórica, que se transformam em referencial para a sua prática pedagógica em sala de aula. 


\section{CONSIDERAÇÕES FINAIS}

A consciência histórica mediada pela linguagem musical possui uma forte carga afetiva elaborada pelos alunos e o professor. Transforma-se em memória pessoal e modelo de referência para a apreensão e assimilação das novas audições, similares ou não as anteriores, revelando, assim, o que podemos chamar de consciência musical dos sujeitos envolvidos.

O processo de identificação da consciência musical se inicia com o reconhecimento dos gostos ligados aos gêneros musicais de alunos e da professora que, além de suscitarem uma busca de identidade por parte dos entrevistados, também estão profundamente ligados a algum uso social em algum momento da história pessoal. Nesse caso, o gosto musical transforma-se em uma representação afetiva da mediação elaborada por alunos e pela professora em relação ao mundo que o cerca. Isso é devido ao caráter eminentemente afetivo; transforma-se em memória pessoal e modelo de referência para a apreensão e assimilação das novas audições dos jovens, similares ou não as anteriores, revelando o que podemos chamar de consciência musical.

Para Schopenhauer, o mundo como representação estaria no gosto musical de cada um de nós, sujeito e objeto se misturam e são revelados através da memória musical. Em tal processo, o sujeito é ativo, uma espécie de artesão que possui a priori três formas puras de conhecimento, todas inatas, presentes nele desde o nascimento e que possibilitam a apreensão do mundo circundante. Essas formas são o tempo, o espaço e a causalidade, espécie de "óculos intelectuais" para se conhecer as coisas, vê-las tais quais aparecem, ou seja, de um exato jeito, não de outro e que vão compor a memória do sujeito, que se revela de forma mais aguçada quando estimulada pela linguagem musical.

Composta basicamente por dois elementos interdependentes, a memória musical remete à identificação e à afetividade. Ao escutarmos uma canção, estabelecemos padrões de identificação a partir de experiências anteriores que são balizadas pela afetividade que, por sua vez, faz parte da memória do sujeito. A lembrança fixada pela memória é uma imagem construída pelos elementos que estão à nossa disposição, no conjunto de representações que povoam nossa consciência no presente. A construção destas imagens quando é estimulada tanto pela afetividade como pelas "paisagens sonoras" da linguagem musical formam uma memória musical que se transforma em uma consciência musical.

Imagens, sentimentos e pensamentos resultantes dos diversos ambientes sociais de 
que fizemos e fazemos parte em nossa vida são significativos na consciência individual. Determinada trilha sonora que compõe a história de cada um vai balizar o nosso gosto e a nossa audição até o final de nossas vidas. Assim, a consciência musical tem uma função prática que confere à realidade direção temporal, orientação que pode guiar intencionalmente a ação por meio da mediação da linguagem musical, auxiliando na construção da memória histórica.

A música auxilia a orientação temporal da subjetividade humana, pois o passado passa a ser articulado de forma mais natural, como estado de coisas, com as orientações presentes no agir contemporâneo dos entrevistados, assim como as determinações de sentido em relação aos conteúdos desenvolvidos em sala de aula. Três foram os pontos analisados para mostrar como essas práticas pedagógicas mediadas pela música interferem e transformam a cultura escolar: a escuta individualizada, a inexpressão corporal e a preservação da cultura do silêncio.

Essa pesquisa demonstrou que as práticas pedagógicas individuais ou coletivas são válidas e interferem na cultura escolar, mas não lhe asseguram a transformação, pois a utilização da linguagem musical apenas estabeleceu estratégias e perspectivas de transformação. Também não garantiu de forma objetiva as condutas regulares da comunidade escolar que alterariam o habitus da cultura escolar, que só poderia ocorrer através do envolvimento da maioria dos agentes envolvidos no processo de aprendizagem, pressupondo um trabalho de inculcação e assimilação que pressupõe tempo e esforço da maioria da comunidade escolar.

Outo ponto relevante refere-se às representações históricas dos alunos e da professora. Estimuladas pela linguagem musical, devem ser pensadas levando em consideração determinados aspectos da música como fenômeno de mediação cultural e suas relações com a linguagem pictórica e escrita.

A utilização dos desenhos como atividade complementar à linguagem musical foi encarada com naturalidade pelos alunos, pois a música acabou formando várias "paisagens sonoras" que foram expressas através da linguagem pictórica. Assim como podemos traduzir em palavras um determinado ambiente, podemos traduzi-lo também em desenhos sonoros enquanto a descrição da paisagem musical desses ambientes. Toda paisagem musical possui recortes, ou seja, elementos distintos que a compõem. Chamamos esses recortes de imagens sonoras, que são acontecimentos auditivos que formam a paisagem sonora ambiental, remetendo-nos a visões pictóricas e a sinais visuais. Utilizo o termo imagem sonora como toda informação sonoro-ambiental que compõe a paisagem musical. Toda informação sonora acrescida ao ambiente torna-se, naquele momento, parte integrante da paisagem sonora; 
descrevê-la é como olhar a nossa volta e traduzir os sons que ouvimos por meio de uma representação gráfica.

O cruzamento entre a linguagem escrita e musical para o entendimento e a fixação dos temas históricos abordados foi fundamentado, em determinados momentos, por exemplificações destacadas pelos alunos durante as entrevistas. Não cabe aqui discutirmos se essas representações apresentadas pelos alunos são válidas ou não, do ponto de vista da ciência histórica, mas é inegável a importância da relação do texto escrito com a linguagem musical na formação da chamada consciência histórica. O importante é que os alunos conseguiram estabelecer relação com um passado recente - composto pelas aulas da professora Marli, o texto do livro didático e a canção na sala de aula, os desenhos, as gravuras e as cenas de uma minissérie - com um presente que, no momento das entrevistas, um ano mais tarde, foi representado pelo texto-estímulo apresentado por mim e as aulas de História na $6^{a}$ série, com outros conteúdos, sem música na sala de aula e com outra professora.

Outro aspecto importante é que as representações históricas dos alunos e da professora estimuladas pela linguagem musical devem também ser pensadas como algo que emerge de determinados processos da vida humana prática, que nos faz inicialmente ouvir emotivamente. Nas esferas do cotidiano familiar, do lazer e da escola a forma emotiva é preponderante, pois ouvir música emotivamente é ouvir mais a si mesmo do que a própria música. É se utilizar da música para que ela desperte ou reforce algo já latente em nós mesmos em busca de uma identidade com o outro.

O conhecimento histórico só é assimilado pelos alunos quando compreendem os vestígios do passado como evidência no mais profundo sentido, ou seja, como algo a ser tratado não apenas como mera informação, mas como algo de onde se possam retirar respostas a questões nunca ali formuladas. Esse tipo de investigação aqui empreendido sugere, a partir de algumas representações históricas do que os estudantes construíram ao longo de sua experiência de vida. Motivados pela linguagem musical, conseguiram lembrar e fazer algum tipo de interpretação em relação aos textos históricos propostos durante as entrevistas. Na maioria dos casos, auxiliou os alunos partirem de questionamentos do presente, refazendo, assim, o caminho das interpretações desenvolvidas em torno dos textos, acrescentando outro e retomando o repertório de significados possíveis em torno dos temas históricos propostos pela professora após um ano.

No caso da professora Marli, um ponto merecedor de destaque foi a necessidade de a docente legitimar externa e internamente à comunidade escolar o seu trabalho com música, buscando não só ganhar capital cultural e se fortalecer politicamente no campo da escola, 
como também estabelecer ligações com o mundo acadêmico, já que, a partir da prática docente pretende desenvolver um projeto de pós-graduação. Nessa perspectiva, coube uma análise da atuação da professora no interior da comunidade escolar a partir de conceitos como campo e habitus do sociólogo PIERRE BORDIEU, que interferiram direta ou indiretamente na relação entre o saber da professora e o trabalho dela na escola e na sala de aula. Essa perspectiva levou a outras reflexões de como as dimensões temporais do saber da professora ao longo de sua história de vida e do seu desenvolvimento ao longo da sua carreira profissional the afetaram a identidade profissional, e quais as características desse saber experiencial baseado na linguagem musical.

Esse saber-fazer da professora mediado pela linguagem musical é estruturado por duas séries de condicionantes: os ligados à transmissão da matéria (condicionantes de tempo, de organização sequencial dos conteúdos, das mediações utilizadas - como no caso da música -, de alcance de finalidades, de aprendizagem por parte dos alunos, de avaliação, etc.) e os ligados à gestão das interações com os alunos (manutenção da disciplina, gestão das ações desencadeadas pelos alunos, motivação da turma...). Portanto, o trabalho da docente no ambiente escolar consistiu em fazer essas duas séries de condicionantes convergirem, em fazê-las colaborar entre si através da linguagem musical.

A professora Marli revelou, a partir da sua prática e da sua narrativa, grande variedade de relações que se estabelecem entre identidade pessoal e identidade profissional. A docente, nesse caso, foi o elemento central, procurando a unificação possível, sendo instigada por múltiplas contradições e ambiguidades auxiliares na construção da sua consciência musical e histórica e transformadoras, já que se tornaram referencial para a prática pedagógica da educadora em sala de aula.

Em suma, a música em sala de aula é importante no processo de aprendizagem. É fundamental para a construção, em sala de aula, do conhecimento histórico revelado, principalmente quando este se encontra relacionado à própria natureza da linguagem musical, que pode ser percebida única e exclusivamente em e mediante o tempo, alimentando-se de uma memória afetiva que se transforma em uma consciência musical no presente, facilitando as narrativas, reflexões, práticas ou interpretações históricas dos alunos e da professora, auxiliando decisivamente na construção da consciência histórica dos principais sujeitos envolvidos nesta pesquisa. 


\section{APÊNDICES}

\section{Apêndice I - Questionário do perfil discente sobre música}

Esta pesquisa tem como objetivo elaborar um perfil dos alunos de uma sala de $6^{\circ}$ ano (antiga $5^{\text {a }}$ série), que estudam em uma escola da rede municipal de São Paulo na região do Pacaembu, onde parte do curso de História é ministrado utilizando-se músicas. Lembrando que essas respostas serão mantidas em sigilo e desde já agradeço pela disposição em colaborar com a pesquisa.

\section{1) Idade:}

2) Sexo: ( )Masculino ( )Feminino

3) Assinale os tipos de música que você mais gosta e escreva os artistas de sua preferência ao lado.

( ) axé

( ) clássica / erudita

( ) forró

( ) funk

( ) gospel / religiosa

( ) $\mathrm{mpb}$

( ) pagode / samba

( ) pop / rock

( ) rap

( ) sertanejo

( ) outros. Quais?

( ) não gosto de música

4) Como você conheceu esses estilos musicais e artistas?

( ) rádio

( ) internet

( ) cinema

( ) televisão

( ) vídeo - dvd

( ) colegas 
( ) escola

( ) família

( ) outros / Quais?

( ) não gosto de música

5) Como você ouve suas músicas preferidas?

( ) aparelho portátil - walkman (fita cassete, cd player, ipod ou celular)

( ) aparelho de som (cd, fita cassete, vinil ou mp3)

( ) rádio - rádio do carro

( ) televisão (vídeo e dvd)

( ) computador

( ) outros / Quais?

( ) não gosto de música

6) Você pratica alguma atividade musical?

( ) Sim / Qual?

( )Não

7) Você ouve música na escola?

( ) aparelho portátil - walkman (fita cassete, cd player, ipod ou celular)

( ) aparelho de som (cd, fita cassete, vinil ou mp3).

( ) computador

( ) rádio

( ) vídeo - dvd

( ) outros / Quais?

( ) não

8) Você já trouxe músicas para as aulas de História?

( ) $\operatorname{Sim}($ )Não

Quais?

9) Você tinha conhecimento anterior de algumas das músicas ou dos artistas que foram apresentados pela professora durante o curso de História?

( ) Sim / Como?

( ) Não 
10) Essas músicas ajudaram você a entender o conteúdo de História?

( ) Sim ( )Não

11) O que mais chamou a sua atenção em relação às músicas?

( ) ritmo

( ) letra

( ) ritmo e letra

( ) nada

12) Qual seria a música ou ritmo de sua preferência para apresentar um trabalho de História para os colegas?

13) Qual seria o tema do trabalho a ser apresentado?

Por quê? 


\section{Apêndice II - Questionário do perfil docente sobre música}

Esta pesquisa tem como objetivo elaborar um perfil parcial de uma professora de Ensino Fundamental II, que estudam em uma escola da rede municipal de São Paulo na região do Pacaembu, onde parte do curso de História é ministrado utilizando-se músicas. Lembrando que essas respostas serão mantidas em sigilo e desde já agradeço pela disposição em colaborar com a pesquisa.

1) Há quanto tempo você atua na sala de aula?:

2) Há quanto tempo você trabalha nesta unidade escolar?

3) Há quantos anos utiliza a música em sala de aula?

4) Assinale os tipos de música que você mais gosta e escreva os artistas de sua preferência ao lado.

( ) axé

( ) clássica / erudita

( ) forró

( ) funk

( ) gospel / religiosa

( ) $\mathrm{mpb}$

( ) pagode / samba

( ) pop / rock

( ) rap

( ) sertanejo

( ) outros. Quais?

( ) não gosto de música

5) Como você conheceu esses estilos musicais e artistas?

( ) rádio
( ) internet
( ) cinema
( ) televisão
( ) vídeo - dvd
( ) colegas
( ) escola
( ) família
( ) outros / Quais?


6) Como você ouve suas músicas preferidas?

( ) aparelho portátil - walkman (fita cassete, cd player, mp3, mp4, mp5 e celular)

( ) aparelho de som (cd, fita cassete ou vinil)

( ) rádio - rádio do carro

( ) televisão (vídeo e dvd)

( ) computador

( ) outros / Quais?

7) Você pratica alguma atividade musical fora da prática pedagógica?

( ) Sim / Qual?

( )Não

8) O que mais chama a sua atenção em relação à música?

( ) ritmo

( ) letra

( ) ritmo e letra

Por quê?

9) Qual seria a música ou ritmo de sua preferência para apresentar um tema de História para alunos e professores?

10) Qual seria o tema do trabalho a ser apresentado?

Por quê? 


\section{Apêndice III - Tabulação dos dados dos questionários do perfil discente}

Tabela 1 - Idade

\begin{tabular}{|c|c|c|}
\hline 11 anos & 12 anos & 13 anos \\
\hline $75 \%$ & $22 \%$ & $3 \%$ \\
\hline
\end{tabular}

Tabela 2 - Sexo

\begin{tabular}{|c|c|}
\hline Feminino & Masculino \\
\hline $56 \%$ & $44 \%$ \\
\hline
\end{tabular}

Tabela 3 - Tipos de música e artistas preferidos

\begin{tabular}{|c|c|l|}
\hline Axé & $19 \%$ & Babado Novo - Claudia Leite (3) e Ivete Sangalo (3). \\
\hline Black & $34 \%$ & $\begin{array}{l}\text { Akon (4), Rihanna (3), Nelly Furtdo (2), 50 Cent (1), Justin } \\
\text { Timberlake (1). }\end{array}$ \\
\hline Clássica / Erudita & $0 \%$ & \\
\hline Forró & $9 \%$ & Bonde do Forró (1) e Camisa Suada (1). \\
\hline Funk & $59 \%$ & $\begin{array}{l}\text { Menor do Chapa (4), Claudinho \& Bochecha (3), Mc Katia (3), } \\
\text { Mc Naldinho (2), Mc Perlla (2), DJ Malboro (1), Mc Leozinho } \\
(1), \text { Mc Magrela (1), Mc Rose (1), Mc Sabrina (1), Mc Sapão } \\
(1), \text { MC's B1 \& B2 (1). }\end{array}$ \\
\hline Gospel / Religiosa & $16 \%$ & Ana Paula Valadão (1), Cristina Mel (1), Kleber Lucas (1). \\
\hline MPB & $22 \%$ & $\begin{array}{l}\text { Guilherme Arantes (4), Alceu Valença (1), Ana Carolina (1), } \\
\text { Elis Regina (1), Fagner (1), Vanessa da Mata (1). }\end{array}$ \\
\hline Pagade / Samba & $25 \%$ & $\begin{array}{l}\text { Exaltasamba (4), Jeito Moleque (4), Inimigos da HP (2), Jorge } \\
\text { Aragão (1), Sorriso Maroto (1), Zeca Pagodinho (1). }\end{array}$ \\
\hline Pop / Rock & $53 \%$ & $\begin{array}{l}\text { Legião Urbana (2), Nx Zero (2), Pitty (2), Backstreet Boy (1), } \\
\text { Black Sabbath (1), Fresno (1), Ira (1), Latino (1), Lulu Santos } \\
(1), \text { Queen (1), Raul Seixas (1), Sandy \& Junior (1), Simple } \\
\text { Plan(1), Strike (1), Vanessa Camargo (1). }\end{array}$ \\
\hline Rap & $16 \%$ & $\begin{array}{l}\text { Racionais Mc's (5), Ao Cubo (3), Expressão Ativa (3), Facção } \\
\text { Central (2), Sabotagem (1). }\end{array}$ \\
\hline Sertanejo & $9 \%$ & $\begin{array}{l}\text { Daniel (1), Grupo Tradição (1), Rick \& Renner (1), Rio Negro } \\
\text { \& Solimões (1), Victor \& Leo (1). }\end{array}$ \\
\hline
\end{tabular}

Tabela 4 - Origem dos 62 artistas citados

\begin{tabular}{|c|c|}
\hline Estrangeiros & Nacionais \\
\hline $15 \%$ & $85 \%$ \\
\hline
\end{tabular}

Tabela 5 - Origem dos ritmos citados

\begin{tabular}{|c|c|}
\hline Estrangeiros & Nacionais \\
\hline $63 \%$ & $37 \%$ \\
\hline
\end{tabular}

Tabela 6 - Contato com os estilos musicais e artistas preferidos.

\begin{tabular}{|c|c|}
\hline Cinema & $3 \%$ \\
\hline Colegas & $37 \%$ \\
\hline Escola & $31 \%$ \\
\hline Família & $41 \%$ \\
\hline Internet & $50 \%$ \\
\hline Rádio & $62 \%$ \\
\hline Televisão & $50 \%$ \\
\hline Vídeo - DVD & $31 \%$ \\
\hline
\end{tabular}


Tabela 7 - Como os alunos escutam músicas.

\begin{tabular}{|c|c|}
\hline Aparelho portátil - walkman (fita cassete, cd player, ipod ou celular) & $75 \%$ \\
\hline Aparelho de som (fita cassete, cd, vinil ou mp3) & $53 \%$ \\
\hline Computador & $69 \%$ \\
\hline Rádio - Rádio do carro & $62 \%$ \\
\hline Televisão (vídeo ou dvd) & $50 \%$ \\
\hline Não especificou & $3 \%$ \\
\hline
\end{tabular}

Tabela 8 - Atividade musical

\begin{tabular}{|c|c|}
\hline Ballet, & $6 \%$ \\
\hline Flauta, gaita, órgão, tamborim (escola de samba), violino & $3 \%$ \\
\hline Gaita & $3 \%$ \\
\hline Órgão & $3 \%$ \\
\hline Tamborim (escola de samba) & $3 \%$ \\
\hline Violino & $3 \%$ \\
\hline Não especificou & $3 \%$ \\
\hline Não pratica atividade musical & $76 \%$ \\
\hline
\end{tabular}

Tabela 9 - Como os alunos escutam música na escola

\begin{tabular}{|c|c|}
\hline Aparelho portátil - walkman (fita cassete, cd player, ipod ou celular) & $53 \%$ \\
\hline Aparelho de som (fita cassete, cd, vinil ou mp3) & $94 \%$ \\
\hline Computador & $28 \%$ \\
\hline Rádio & $6 \%$ \\
\hline Televisão (vídeo ou dvd) & $6 \%$ \\
\hline
\end{tabular}

Tabela 10 - Alunos que trouxeram músicas para as aulas de História

\begin{tabular}{|c|c|}
\hline Sim & Não \\
\hline $12 \%$ & $88 \%$ \\
\hline
\end{tabular}

Tabela 11 - Tipos de música e artistas trazidos pelos alunos para as aulas de História

\begin{tabular}{|c|c|}
\hline Funk & Claudinho \& Bochecha. \\
\hline MPB & Guilherme Arantes. \\
\hline Música Folclórica & Música folclórica grega. \\
\hline Pop / Rock & Ira, Legião Urbana, Queen. \\
\hline
\end{tabular}

Tabela 12 - Conhecimento dos alunos de uma das músicas ou um dos artistas que foram apresentados pela professora durante o curso de História

\begin{tabular}{|l|l|}
\hline Sim & Não \\
\hline $41 \%$ & $59 \%$ \\
\hline
\end{tabular}

Tabela 13 - Como os alunos tiveram contato anterior com as músicas e artistas apresentados pela professora durante o curso

\begin{tabular}{|c|c|}
\hline Família & $23 \%$ \\
\hline Rádio do carro & $23 \%$ \\
\hline Não especificou & $54 \%$ \\
\hline
\end{tabular}


Tabela 14 - As músicas e artistas apresentados pela professora ajudaram a entender o conteúdo de História

\begin{tabular}{|c|c|}
\hline Sim & Não \\
\hline $100 \%$ & ----- \\
\hline
\end{tabular}

Tabela 15 - Elementos das músicas apresentas que mais chamaram a atenção dos alunos

\begin{tabular}{|c|c|}
\hline Ritmo & $3 \%$ \\
\hline Letra & $3 \%$ \\
\hline Ritmo e Letra & $94 \%$ \\
\hline Nada & -------- \\
\hline
\end{tabular}

Tabela 16 - Ritmo de preferência e tema escolhido pelos alunos para apresentar um trabalho de História para os colegas

\begin{tabular}{|c|c|c|}
\hline Ritmos & Temas & $3 \%$ \\
\hline Black & Violência e racismo. & $37 \%$ \\
\hline MPB & Índios, preservação do planeta e problemas da cidade grande. & $6 \%$ \\
\hline Pop Rock & História do rock. & $6 \%$ \\
\hline Rap & Injustiça social. & $48 \%$ \\
\hline Não especificou & Não especificou & 38 \\
\hline
\end{tabular}




\section{Apêndice IV - Roteiro das entrevistas dos alunos e textos}

- Exibição e tentativa de identificação dos temas históricos relacionados aos textos por parte do entrevistado.

- $\quad$ Caso não haja a identificação o entrevistador deverá fazê-lo.

- Após a identificação dos textos será solicitado ao entrevistado que faça comentários sobre cada um deles, relacionando-os com as respectivas músicas trabalhadas em sala de aula no ano letivo anterior.

- $\quad$ Caso não haja identificação das músicas o entrevistador deverá fazê-lo.

- Feitos os comentários será solicitado que o mesmo tente estabelecer relações do texto com outras músicas.

- A partir das idéias apresentadas pelo entrevistado, solicitar que o mesmo faça comentários finais sobre a importância da música para as aulas de História. 


\section{Apêndice V - Tabulação das oito entrevistas dos alunos}

Tabela 1 - Identificação dos temas através dos textos

\begin{tabular}{|c|c|c|}
\hline Temas e textos & Sim & Não \\
\hline Texto 1 - Comunidades Tribais & 7 & 1 \\
\hline Texto 2 - Civilizações do Oriente Próximo (Egito e Mesopotâmia) & 8 & - \\
\hline Texto 3 - As Mulheres da Grécia Antiga & 6 & 2 \\
\hline Texto 4 - A Urbanização de São Paulo (final do século XIX e inicio do século XX) & 7 & 1 \\
\hline
\end{tabular}

Tabela 2 - Relação entre os textos e as músicas ouvidas em sala de aula

\begin{tabular}{|c|c|c|}
\hline Textos e músicas & Sim & Não \\
\hline $\begin{array}{c}\text { Texto } 1 \text { - Comunidades Tribais e "Curumim chama cunhatã que eu vou cantar (todo dia } \\
\qquad \text { era dia de índio)" (Jorge Ben Jor) }\end{array}$ & 7 & 1 \\
\hline $\begin{array}{c}\text { Texto } 2 \text { - Civilizações do Oriente Próximo (Egito e Mesopotâmia) e "Planeta água” } \\
\text { (Guilherme Arantes) }\end{array}$ & 4 & 4 \\
\hline $\begin{array}{c}\text { Texto } 3 \text { - As Mulheres da Grécia Antiga e “Mulheres de Atenas” (Chico Buarque de } \\
\text { Holanda) }\end{array}$ & 6 & 2 \\
\hline $\begin{array}{l}\text { Texto } 4 \text { - A Urbanização de São Paulo (final do século XIX e inicio do século XX) e } \\
\text { "São Paulo, São Paulo" (Premê) }\end{array}$ & 8 & - \\
\hline
\end{tabular}

Tabela 3 - Relação entre os textos e outras músicas sugeridas pelos alunos

\begin{tabular}{|c|c|c|}
\hline Textos e músicas & Sim & Não \\
\hline Texto 1 - Comunidades Tribais e "Índios" (Legião Urbana) & 1 & 7 \\
\hline $\begin{array}{c}\text { Texto } 2 \text { - Civilizações do Oriente Próximo (Egito e Mesopotâmia) e "Água mineral" } \\
\text { (Carlinhos Brown) }\end{array}$ & 1 & 7 \\
\hline Texto 3 - As Mulheres da Grécia Antiga & - & - \\
\hline Texto 4 - A Urbanização de São Paulo (final do século XIX e inicio do século XX) & - & - \\
\hline
\end{tabular}

Tabela 4 - Relação entre os textos, as músicas e outras linguagens trabalhadas em sala de aula

\begin{tabular}{|c|c|c|}
\hline Textos, músicas e outras linguagens & Sim & Não \\
\hline Texto 1 - Comunidades Tribais e a minissérie "A muralha" & 1 & 7 \\
\hline $\begin{array}{l}\text { Texto } 2 \text { - Civilizações do Oriente Próximo (Egito e Mesopotâmia) e elaboração de } \\
\text { desenhos }\end{array}$ & 1 & 7 \\
\hline Texto 3 - As Mulheres da Grécia Antiga e elaboração de desenhos & 1 & 7 \\
\hline $\begin{array}{l}\text { Texto } 4 \text { - A Urbanização de São Paulo (final do século XIX e inicio do século XX) e a } \\
\text { minissérie "A muralha“" }\end{array}$ & 3 & 5 \\
\hline $\begin{array}{l}\text { Texto } 4 \text { - A Urbanização de São Paulo (final do século XIX e inicio do século XX) e a } \\
\text { elaboração de cartazes com gravuras }\end{array}$ & 2 & 6 \\
\hline
\end{tabular}




\section{Apêndice VI - Identificação e relação dos textos com as músicas}

Quadro 1 - Identificação do texto 1 relacionando-o à música “Curumim chama cunhatã que eu vou cantar (todo dia era dia de índio)” (Jorge Ben Jor)

\begin{tabular}{|c|c|}
\hline Discurso & Representações \\
\hline $\begin{array}{l}\text { - "O modo de vida deles (índios) cuidando da } \\
\text { - } \quad \text { "Serra". } \\
\text { eles n madeira a gente fica sem muitas coisas e } \\
\text { natureza (...). Não pode matar bicho à toa". } \\
\text { "Lembro dos índios que não matavam os animais } \\
\text { apenas porque queriam, agora quando chegaram } \\
\text { os portugueses eles começaram a fazer isso, } \\
\text { matavam e escravizam os índios". } \\
\text { "O texto fala do desmatamento e do cortar as } \\
\text { árvores e dos índios". } \\
\text { "Só retiravam o necessário para a caça, para a } \\
\text { pesca e fazer arcos". } \\
\text { "O texto fala que não podemos matar animais à } \\
\text { toa, apenas para sobreviver no mato, quando o } \\
\text { indio corta o mato ou mata um animal é para } \\
\text { sobreviver". } \\
\text { "O texto fala dos índios e da terra que a gente não } \\
\text { acabar". }\end{array}$ & $\begin{array}{ll}\text { - } & \text { Preservação da natureza. } \\
\text { - } & \text { Economia de subsistência. } \\
\text { - } & \text { Exploração do português. }\end{array}$ \\
\hline
\end{tabular}

Quadro 2 - Identificação do texto 2 relacionando-o à música “Planeta água” (Guilherme Arantes)

\begin{tabular}{|c|c|}
\hline Discurso & \multicolumn{1}{c|}{ Representações } \\
\hline • "A importância da água para as primeiras & $\bullet$ Importância dos grandes rios \\
civilizações do Egito e da Mesopotamia". & para a formação das primeiras \\
- "Lembra sobre o Egito, o Nilo, o Eufrates e a & civilizações. \\
música, que fala dos vales e dos rios". & Preservação da natureza. \\
"O texto trata do Egito, do rio Nilo e do rio Tigre & \\
e da importância dos rios para os agricultores". & \\
"O texto fala do sobre os rios Nilo, Tigre e & \\
Eufrates, o Egito Antigo e a Mesopotâmia. Como a que fala da importância da água e faz & \\
lembrar sobre o Egito".
\end{tabular}


Quadro 3 - Identificação do texto 3 relacionando-o à música "Mulheres de Atenas" (Chico Buarque de Holanda)

\begin{tabular}{|c|c|}
\hline Discurso & Representações \\
\hline "A vida das mulheres de Atenas na Grécia Antiga, & $\bullet$ A condição inferior e de \\
pois os pais é que escolhiam o casamento e & dependência social das mulheres \\
pagavam para que elas arrumassem um marido". & em relação aos homens (pais e \\
"Lembro de Atenas onde os homens não & maridos). \\
respeitavam as mulheres". & Apresentavam algum tipo de \\
"O texto me fez lembrar que a professora falou & resistência emão à \\
que colocavam as mulheres no prédio e & condição de inferioridade. \\
queimavam na Grécia. Isso me fez lembrar da \\
música. Elas foram queimadas porque elas se \\
revoltaram". \\
"O texto fala das mulheres e dos maridos na \\
Grécia. Como a música que fala das mulheres que \\
só tinham um cômodo pra elas e só podiam \\
trabalhar em casa. Os maridos iam para a guerra, \\
quando ficavam de quarentena e não podiam \\
comer alguma coisa ou fazer alguma coisa".
\end{tabular}


Quadro 4 - Identificação do texto 4 relacionando-o à música “São Paulo, São Paulo” (Preme)

\begin{tabular}{|c|c|}
\hline Discurso & Representações \\
\hline 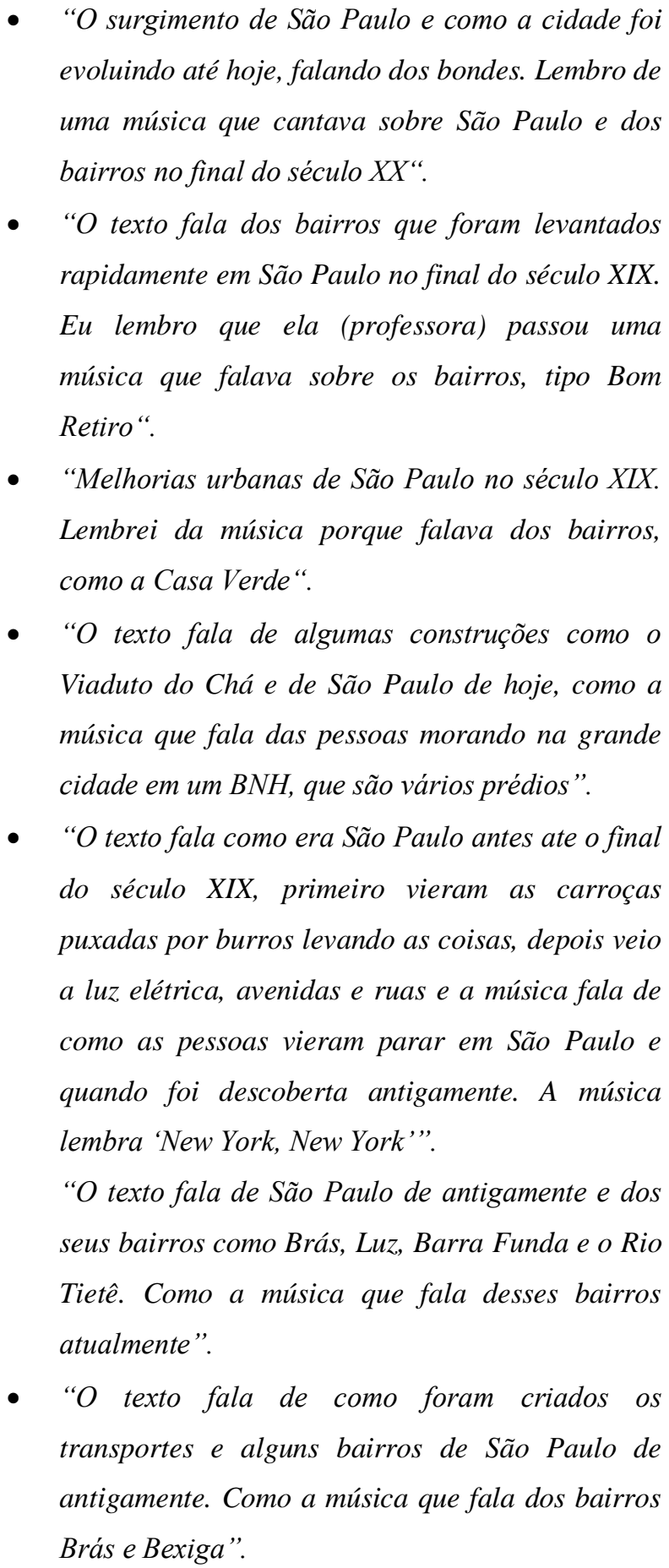 & $\begin{array}{l}\text { A urbanização de São Paulo através das } \\
\text { seguintes representações: } \\
\text { - Formação dos seus bairros. } \\
\text { - Grandes obras públicas. } \\
\text { - Desenvolvimento dos meios de } \\
\text { transporte. } \\
\text { - Desenvolvimento tecnológico. } \\
\text { - Pólo de atração e concentração } \\
\text { humana. }\end{array}$ \\
\hline
\end{tabular}




\section{Apêndice VII - Roteiro da entrevista da professora}

- $\quad$ Falar da influência e da relação com a música antes de se tornar professora.

- Qual a influência da música na sua formação profissional?

- $\quad$ Como você constrói a sua aula utilizando a linguagem musical?

- Como você estabelece a relação entre a música e o conteúdo?

- A utilização deste tipo de linguagem em sala de aula sempre se deu da mesma forma?

- Você pensaria em outras músicas além das que eu observei para os temas escolhidos na $5^{\mathrm{a}}$ série?

- Você destacaria outros temas que poderiam ser tratados através da música para a $5^{\text {a }}$ série?

- $\quad$ E nas demais séries?

- Como os alunos “aprendem” História através da linguagem musical?

- Qual a importância da música nas suas aulas levando em conta os depoimentos de exalunos? (lembrando que eu tenho os depoimentos dos alunos dela no Orkut).

- $\quad$ Por que os professores não utilizam com maior freqüência a música em sala de aula? (lembrando que ela ministra cursos para outros professores).

- Quais as outras linguagens que você utiliza em sala de aula?

- Qual a relação destas linguagens com a música?

- Como os alunos estabelecem a relação entre essas linguagens?

- Como você vê a música no âmbito da cultura da escola?

- Quais os resultados obtidos com a utilização da música em sala de aula em dois níveis?

○ Pedagógico

- Profissional

- $\quad$ Considerações finais da professora. 


\section{Apêndice VIII - Tabulação do perfil da professora (questionário e entrevista)}

\section{Quadro 1- Sexo}

Feminino

Quadro 2- Tempo de sala de aula

28 anos

Quadro 3- Tempo na unidade escolar

4 anos

Quadro 4- Tipos de música e artistas preferidos

\begin{tabular}{|c|c|}
\hline Axé & \\
\hline Black & Mozart. \\
\hline Clássica / Erudita & Luiz Gonzaga. \\
\hline Forró & \\
\hline Funk & Marisa Monte. \\
\hline Gospel / Religiosa & Caetano Veloso, Chico Buarque, Zizi Possi, Gal Costa, Maria Bethânia e \\
\hline MPB & Ney Matogrosso e Secos \& Molhados, Legião Urbana, Raul Seixas, Rita \\
\hline Pagade / Samba & Pee, Cazuza e Barão Vermelho, Ultraje A Rigor, Titãs, The Beatles e Elvis \\
\hline Pop / Rock & \\
\hline Rap & \\
\hline Sertanejo & Tonico \& Tinoco e Inezita Barroso \\
\hline Outros & Nelson Gonçalves \\
\hline
\end{tabular}

Quadro 5- Origem dos 24 artistas citados

\begin{tabular}{|c|c|}
\hline Estrangeiros & Nacionais \\
\hline $13 \%$ & $87 \%$ \\
\hline
\end{tabular}


Quadro 6- Contato com os estilos musicais e artistas preferidos.

\begin{tabular}{|c|l|}
\hline Cinema & Não \\
\hline Colegas & Não \\
\hline Escola & Sim \\
\hline Família & Sim \\
\hline Internet & Não \\
\hline Rádio & Sim \\
\hline Televisão & Sim \\
\hline Vídeo - DVD & Sim \\
\hline
\end{tabular}

Quadro 7- Como a professora escuta suas músicas.

\begin{tabular}{|c|c|}
\hline Aparelho portátil - walkman (fita cassete, cd player, ipod ou celular) & Não \\
\hline Aparelho de som (fita cassete, cd, vinil ou mp3) & Sim \\
\hline Computador & Não \\
\hline Rádio - Rádio do carro & Sim \\
\hline Televisão (vídeo ou dvd) & Sim \\
\hline
\end{tabular}

Quadro 8- Atividade musical

Não pratica atividade musical

Quadro 9- O que mais chama a sua atenção em relação à música

Ritmo e Letra

Quadro 10- Ritmo de preferência e tema escolhido alunos para apresentar um trabalho de História para alunos e professores

\begin{tabular}{|c|c|c|}
\hline Ritmo & Música & Tema \\
\hline MPB & "Sinfonia Paulistana" de Billy Blanco & São Paulo \\
\hline
\end{tabular}

Quadro 11- Influência musical na infância e adolescência

\begin{tabular}{|c|}
\hline Cresceu ouvindo o rádio e cantando o repertório da jovem guarda \\
\hline O pai ouvia Adoniran Barbosa interpretado pelos Demônios da Garoa (trabalhou em sala de aula) \\
\hline A mãe ouvia Nelson Gonçalves \\
\hline $\begin{array}{c}\text { Na casa da avó materna havia uma vitrola que propiciava a transformação dos encontros familiares em } \\
\text { bailes (Luiz Gonzaga, Clara Nunes e Martinho da Vila - já trabalhou uma canção deste último em sala } \\
\text { de aula) }\end{array}$ \\
\hline Programa de rádio "Barros de Alencar" ("música brega “) \\
\hline Nos anos 70: Raul Seixas, Rita Lee e Secos \& Molhados (maior influência da televisão) \\
\hline Rádio Difusora AM (final dos anos 70) e Radio Cidade FM (início dos anos 80) \\
\hline
\end{tabular}


Quadro 12- Influência musical na escola

\begin{tabular}{|c|}
\hline Músicas cantadas em datas comemorativas (anos 70) \\
\hline Aulas de Inglês: The Platers, Elvis Presley e Frank Sinatra \\
\hline Letras utilizadas nas aulas de Português sem a música (ginásio e colegial) \\
\hline
\end{tabular}

Quadro 13- Influência musical na época de faculdade e no início da carreira do magistério

\begin{tabular}{|c|}
\hline Principais influências: Raul Seixas, Rita Lee, Ney Matogrosso e Cazuza \\
\hline O sucesso da geração do rock brasileiro dos anos 80 (Blitz, Barão Vermelho, Ultraje A Rigor e Titãs) \\
coincide com a entrada da professora em sala de aula.
\end{tabular}

Quadro 14- Influência musical atualmente

\begin{tabular}{|c|}
\hline Ver questionário \\
\hline Ouve as rádios Antena 1 FM e Alpha FM \\
\hline
\end{tabular}

Quadro 15- A aplicação da linguagem musical na época da faculdade e no início da carreira do magistério

• "Na época de faculdade não pensava em utilizar música em sala de aula”.

- "Isso ocorreu na prática, quando ainda era professora P2 (professora eventual), substituindo outros professores".

Quadro 16- A construção da aula utilizando a linguagem musical

- "Trabalho primeiro o conteúdo através do livro didático ou de um eixo temático com textos complementares".

- "Procuro e trabalho canções que se relacionam com o conteúdo".

Quadro 17- A relação entre música e conteúdo

- "Aula expositiva explorando o vocabulário da letra da canção".

- "Releitura da letra identificando determinados versos e relacionando-os ao conteúdo".

- "Nas aulas expositivas sempre volto a fazer referência à música trabalhada anteriormente”

- “Da $5^{a}$ série até a $7^{a}$ série procuro partir do conteúdo para a música”.

- "Na $5^{a}$ série procuro trazer canções, cuja temática esteja mais explícita”.

- “A partir da $7^{a}$ série peço para os alunos pesquisarem e trazerem músicas relacionadas ao tema alunos para serem comparadas ao repertório da professora". 
Quadro 18- A relação entre a música e outras linguagens

- "Utilizo imagens do livro didático ou outras imagens para relacionar com a música”.

- $\quad$ "Os alunos devem elaborar um desenho que se refere à letra com uma pequena legenda e um texto explicativo“.

- $\quad$ "Sempre procuro utilizar uma mesma sequência até a $7^{a}$ série: texto, música, imagens e filme (algumas cenas)"”.

- "Quando o filme é utilizado integralmente torna-se a linguagem principal. Quando há possibilidade também exploro a trilha sonora do filme”.

Quadro 19- Outras músicas que poderiam ser utilizadas na 5 série

- “'Tribos dos Carajás' de Martinho da Vila. Apenas a letra foi trabalhada em anos anteriores, pois eu não possuo a gravação”.

Quadro 20- O “aprender” História através da linguagem musical

- $\quad$ "Porque os alunos gostam de cantar, fazendo da música um elemento motivador para eles aprenderem História",

- “A música facilita a memorização e a motivação para o entendimento do conteúdo”.

- "Altera a visão que os alunos têm sobre um determinado tema histórico”.

- “A troca de repertórios provoca uma aproximação entre professor e alunos, facilitando a mediação”.

Quadro 21- A importância da música nas aulas de História para os ex-alunos (contatos através da Internet)

- "Porque eles lembram das aulas através das músicas e dos intérpretes".

- "Lembram das atividades ligadas à música, principalmente dos desenhos”.

- "Acabam tomando gosto pelo repertório através da contextualização histórica”.

- "Desperta o gosto crítico em relação à música”.

Quadro 22- A utilização esporádica da música na sala de aula pelos professores

- "Eles gostam, mas não sabem como utilizar, evidenciando uma falta de criatividade".

- "O medo dos professores da música ser considerada chata pelos alunos".

- “Alguns trabalham a letra sem a música”.

- “A linguagem musical já se encontra incorporada a minha prática docente, enquanto para outros é novidade”.

Quadro 23- A relação entre a música e as demais linguagens na sala de aula

- "As linguagens devem ser utilizadas como suporte para o conteúdo e as aulas expositivas".

- “As mediações entre as linguagens e destas com os conteúdos devem ser feitas através do professor". 


\section{Quadro 24- A música e a cultura escolar}

- "A música ainda é vista como barulho na escola, o que, algumas vezes, motiva reclamações dos outros professores”.

- “A cultura escolar ainda é vista como a cultura do silêncio, o professor e a sua aula expositiva com os alunos escutando sentados em silêncio".

- "Na escola continua a rádio e a escuta individualizada (mp3, mp4 e celulares)”.

- “A rádio serve para socializar os gostos dos alunos, às vezes peço para eles levarem as suas musicas para a sala de aula”.

- $\quad$ “As vezes eles levam musicas que se referem às musicas e aos artistas trabalhados em sala de aula, que muitas vezes eles escutam e baixam do computador, com o mp3 não existe mais a cultura do disco”,

- $\quad$ “As músicas que os alunos trazem não têm quase letra e sim ritmos e batidas eletrônicas que vêm do funk".

- ' 'O coordenador Cláudio saiu da escola no ano passado (2008) e o projeto da 'aula pública', que foi trazido por mim e ampliado pelo coordenador em 2007 terminou."

- “Com o fim do projeto a 'aula pública' permaneceu como uma ação isolada, quando apresento as músicas com os alunos no pátio, nos vinte minutos finais da ultima aula, em uma data prédeterminada pela direção da escola”.

\section{Quadro 25- Os resultados profissionais da professora com a sua prática pedagógica}

- “A satisfação pessoal e de prazer em sala de aula estão em primeiro plano”.

- “O 'Prêmio Paulo Freire', veio trazer a respeitabilidade institucional e a visibilidade sobre o meu trabalho, fortalecendo-o profissionalmente”.

- “A música na sala de aula trouxe visibilidade e legitimou a minha prática pedagógica, que resultou em cursos de aperfeiçoamento para professores de várias disciplinas e um livro como relato desta prática”.

- “A maioria dos professores acredita que o sucesso de uma prática pedagógica deva se restringir a sala de aula e não há preocupação em socializá-la”.

- "Cabe a academia legitimar a minha prática e a minha metodologia através de uma fundamentação científica”.

- "A minha metodologia é baseada apenas na intuição e na emoção que provoca nos alunos".

- $\quad$ "No conteúdo eu não posso intervir, mas a minha metodologia encontra-se incorporada na legislação, escutar música na sala de aula não é mais uma pratica marginal, quando o diretor ainda mandava desligar o rádio”. 


\begin{abstract}
ANEXOS
Anexo I- Textos de livros didáticos e paradidáticos utilizados durante as entrevistas
\end{abstract}

\title{
Texto 1
}

"A terra não era de um dono só.

A terra era de toda a comunidade.

É na terra que a gente planta a nossa roça. (...)

A terra dá toda fruta do campo, dá toda fruta do mato. (...)

O mato não pode acabar.

Por isso, nós não cortamos pau à toa. Nós só cortamos pau precisando fazer casa, precisando fazer fogo:

Precisando fazer canoa, precisando fazer pinguela, precisando fazer arco. Só quando é preciso!

Nós também não matamos os bichos à toa. Só matamos a caça para comer."

(CIMI. História dos Povos Indígenas - 500 anos de luta no Brasil. $3^{a}$ ed.. Petrópolis: Vozes, 1986.P p. 12-13. Apud MARQUES, BERUTTI \& FARIA. História: Os caminhos do homem.

Vol. 1. Belo Horizonte: Lê, 1999. P. 62.).

\section{Texto 2}

"O surgimento da agricultura levou os homens a trabalharem em grupo e a procurarem locais adequados para sua nova atividade. Assim, as primeiras civilizações nasceram em torno de grandes rios na Mesopotâmia, , no vale dos rios Tigre e Eufrates; Egito, no vale do Nilo; índia no do Ganges e do Indo; China, no do Amarelo.

Apesar de estes rios fertilizarem a terra e permitirem boas colheitas, havia necessidade de se levar suas águas até locais mais distantes por meio de canais de irrigação e de, em certos pontos, construir diques para impedir enchentes destruidoras. Desta forma era preciso um poder central que coordenasse todos esses trabalhos, defendesse o território contra outros povos e interferisse junto aos deuses em favor da fertilidade para a terra e para os animais. Foram assim organizados Estados, com muitos funcionários e ligados à religião." (FRANCO JR, Hilário \& CHACON, Paulo Pan. História econômica geral e do Brasil. São Paulo: Atlas, 1980. P. 18. Apud RICARDO, ADHEMAR \& FLÁVIO. Construindo a História. Vol. 1. Belo Horizonte: Lê, 1988.P p.55-56.). 


\section{Texto 3}

"De tudo o que tem vida e pensamento, somos nós, mulheres, as criaturas mais miseráveis. Em primeiro lugar, gastamos o dinheiro do dote para comprar um marido, pagando mais do que ele merece. E, assim, arranjamos um dono para o nosso corpo, o que é um mal ainda maior do que o outro. Em seguida, vem o grave problema de saber se a escolha foi boa ou má. Pois há sempre escândalo em recorrer ao divórcio, e as mulheres não podem repudiar o marido." (EURÍPEDES. Medeia. Transcrito por MASSEY, Michael. As mulheres na Grécia e Roma antigas. Lisboa: Europa-América,1988. Pp.19-20. Apud DUARTE, Gleuso Damasceno. Tempos de História. Vol. 1. Belo Horizonte: Lê, 2000. P.86).

\section{Texto 4}

Até o final do século XIX, São Paulo ainda guardava um aspecto provinciano. O núcleo urbano central, em torno do Pátio do Colégio, onde a cidade nasceu, não havia ultrapassado os vales do Anhangabaú e do Tamanduateí. Havia ainda muitos espaços vazios, chácaras e sítios. A construção do primeiro viaduto, o do Chá, inaugurado em 1892, foi fundamental para a expansão urbana.

Abriu-se então uma nova era de reformas e progressos (...). Os trilhos das ferrovias rasgaram as áreas planas vizinhas aos rios Tietê e Tamanduateí, regiões alagadiças que até então haviam permanecido praticamente desertas. Armazéns, depósitos, oficinas e indústrias foram atraídos pela facilidade dos transportes. Os terrenos relativamente baratos foram sendo ocupados pelos imigrantes. Novos bairros surgiram, como, por exemplo, Brás, Luz, Barra Funda, Bom Retiro, Mooca, Belenzinho. (...)

Nas partes altas da cidade surgiam as ruas e os bairros, tipicamente residenciais, destinados aos mais abastados e nos quais os cafeicultores e industriais erguiam seus elegantes palacetes: Paulista, Campos Elísios, Higienópolis, Jardins.

As melhorias urbanas, ainda que distribuídas de forma desigual ao longo da cidade, foram sendo implantadas: calçamento das ruas, sistemas de água encanada e esgotos, luz elétrica em lugar dos lampiões, substituição dos bondes puxados por burros por bondes elétricos, escolas, bancos, casas comerciais, teatros, livrarias e cafés.

(LUCA, Tania Regina de. Café e modernização. São Paulo. Atual, 2000. Pp.29-32 - Á vida no tempo). 


\section{Anexo II- Letras das músicas utilizadas pela professora}

1. “Curumim chama cunhatã que eu vou cantar (todo dia era dia de índio)” (1981) de Jorge Ben Jor

Curumim,chama Cunhatã

Que eu vou contar

Curumim,chama Cunhatã

Que eu vou contar

Todo dia era dia de índio

Todo dia era dia de índio

Curumim, Cunhatã

Cunhatã, Curumim

Antes que o homem aqui chegasse

Às Terras Brasileiras

Eram habitadas e amadas

Por mais de 3 milhões de índios

Proprietários felizes

Da Terra Brasilis

Pois todo dia era dia de índio

Todo dia era dia de índio

Mas agora eles só tem

O dia 19 de Abril

Mas agora eles só tem

O dia 19 de Abril

Amantes da natureza

Eles são incapazes

Com certeza

De maltratar uma fêmea

Ou de poluir o rio e o mar

Preservando o equilíbrio ecológico

Da terra, fauna e flora

Pois em sua glória, o índio

É o exemplo puro e perfeito

Próximo da harmonia 
Da fraternidade e da alegria

Da alegria de viver!

Da alegria de viver!

E no entanto, hoje

O seu canto triste

É o lamento de uma raça que já foi muito feliz

Pois antigamente

Todo dia era dia de índio

Todo dia era dia de índio

Curumim, Cunhatã

Cunhatã, Curumim

Terêrê, oh yeah!

Terêreê, oh! 
2. "Planeta água" (1981) de Guilherme Arantes

Água que nasce na fonte

Serena do mundo

E que abre um

Profundo grotão

Água que faz inocente

Riacho e deságua

$\mathrm{Na}$ corrente do ribeirão...

Águas escuras dos rios

Que levam

A fertilidade ao sertão

Águas que banham aldeias

E matam a sede da população...

Águas que caem das pedras

No véu das cascatas

Ronco de trovão

E depois dormem tranqüilas

No leito dos lagos

No leito dos lagos...

Água dos igarapés

Onde Iara, a mãe d'água

É misteriosa canção

Água que o sol evapora

Pro céu vai embora

Virar nuvens de algodão...

Gotas de água da chuva

Alegre arco-íris

Sobre a plantação

Gotas de água da chuva

Tão tristes, são lágrimas

$\mathrm{Na}$ inundação...

Águas que movem moinhos

São as mesmas águas

Que encharcam o chão 
E sempre voltam humildes

Pro fundo da terra

Pro fundo da terra...

Terra! Planeta Água

Terra! Planeta Água

Terra! Planeta Água...

Água que nasce na fonte

Serena do mundo

E que abre um

Profundo grotão

Água que faz inocente

Riacho e deságua

Na corrente do ribeirão...

Águas escuras dos rios

Que levam a fertilidade ao sertão

Águas que banham aldeias

E matam a sede da população...

Águas que movem moinhos

São as mesmas águas

Que encharcam o chão

E sempre voltam humildes

Pro fundo da terra

Pro fundo da terra...

Terra! Planeta Água

Terra! Planeta Água

Terra! Planeta Água 
3. "Mulheres de Atenas" (1976) de Chico Buarque de Holanda

Mirem-se no exemplo

Daquelas mulheres de Atenas

Vivem pros seus maridos

Orgulho e raça de Atenas

Quando amadas se perfumam

Se banham com leite, se arrumam

Suas melenas

Quando fustigadas não choram

Se ajoelham, pedem imploram

Mais duras penas, cadenas

Mirem-se no exemplo

Daquelas mulheres de Atenas

Sofrem pros seus maridos

Poder e força de Atenas

Quando eles embarcam soldados

Elas tecem longos bordados

Mil quarentenas

E quando eles voltam, sedentos

Querem arrancar, violentos

Carícias plenas, obscenas

Mirem-se no exemplo

Daquelas mulheres de Atenas

Despem-se pros maridos

Bravos guerreiros de Atenas

Quando eles se entopem de vinho

Costumam buscar um carinho

De outras falenas

Mas no fim da noite, aos pedaços

Quase sempre voltam pros braços

De suas pequenas, Helenas

Mirem-se no exemplo

Daquelas mulheres de Atenas

Geram pros seus maridos 
Os novos filhos de Atenas

Elas não têm gosto ou vontade

Nem defeito, nem qualidade

Têm medo apenas

Não tem sonhos, só tem presságios

O seu homem, mares, naufrágios

Lindas sirenas, morenas

Mirem-se no exemplo

Daquelas mulheres de Atenas

Temem por seus maridos

Heróis e amantes de Atenas

As jovens viúvas marcadas

E as gestantes abandonadas, não fazem cenas

Vestem-se de negro, se encolhem

Se conformam e se recolhem

As suas novenas

Serenas

Mirem-se no exemplo

Daquelas mulheres de Atenas

Secam por seus maridos

Orgulho e raça de Atenas 


\section{BIBLIOGRAFIA}

ABUD, Katia Maria. "O livro didático e a popularização do saber histórico”. In; SILVA, Marco A. Da Silva (org.). Repensando a história. Rio de Janeiro: Marco Zero / ANPUH, 1984. Pp. 81-91.

"Processos de construção do saber histórico". In: Revista História \& Ensino. Londrina: UEL, v. 11, set. / dez.. 2005. Pp. 25-34.

"Registro e representação do cotidiano: a música popular na aula de

História”. In: Cadernos do CEDES. Campinas: UNICAMP, v. 25, nº 67, 2005. Pp. 309-317.

ADORNO, Theodor W. "A indústria cultural”. In: COHN, Gabriel. (org.). Theodor W. Adorno: sociologia. São Paulo: Ática, 1986. Pp. 92-99. (Coleção grandes cientistas sociais, $54)$.

ADORNO, Theodor W. / HORKHEIMER, Max. "A indústria cultural: o esclarecimento como mistificação das massas".. In: . Dialética do esclarecimento. Rio de Janeiro: Jorge Zahar, 2006. Pp. 99-138.

ADORNO, Theodor W. "Moda sem tempo: sobre o jazz". In: Revista Civilização Brasileira. Rio de Janeiro: Civilização Brasileira, nº 18, março-abril de 1968. Pp. 185-197.

. "Sobre música popular". In: COHN, Gabriel. (org.). Theodor W.

Adorno: sociologia. São Paulo: Ática, 1986. Pp. 115-146. (Coleção grandes cientistas sociais, $54)$.

ALVES, Ronaldo Cardoso.Representações sociais e a construção da consciência histórica. Dissertação de mestrado. São Paulo: FEUSP, 2006.

ALVES, Ronaldo Cardoso \& DUARTE, Milton Joeri Fernandes. "Letras de música e aprendizagem de história”. In: ABUD, Katia Maria; ALVES, Ronaldo Cardoso; SILVA, André Chaves de Melo. Ensino de História. São Paulo: Cengage Learning, 2010. Pp. 59-78. (Coleção Ideias em Ação / Coordenação Anna Maria Pessoa de Carvalho).

ALVES-MAZZOTTI, Alda Judith. "Representações sociais: aspectos teóricos e aplicações à educação”. In: Em Aberto. Brasília: INEP, nº 61, 1994. Pp. 60-78.

ANDRÉ, Marli Eliza D. A. de. Etnografia da prática escolar. $8^{\mathrm{a}}$ ed. Campinas, São Paulo: Papirus, 2002. (Série prática pedagógica).

ASHBY, Rosalyn. "O conceito de evidência histórica: exigências curriculares e concepções de alunos". In: BARCA, Isabel (org.). Educação histórica e museus. Braga: Centro de 
Estudos em Educação e Psicologia - Instituto de Educação e Psicologia Universidade do Minho, 2003. Pp. 19-36.

AUDIGIER, François. "Um estudio sobre la ensñanza de la historia, la geografia y La educación cívica em la escuela fundamental de Francia: temas, métodos y perguntas”. In: Enseñanza de las Ciencias Sociales - Revista de investigación. Institut de Ciències de 1' Universitat Autónoma de Barcelona - Institut de Ciències de l`Educació de la Universitat de Barcelona, $\mathrm{n}^{\circ}$ 1, marzo de 2002. Pp. 3-16.

BAKHTIN, Mikail. Estética da criação verbal. 3a ed. São Paulo: Martins Fontes, 2000 (Coleção ensino superior).

BARBIER, René. “Sobre o imaginário”. In: Em Aberto. Brasília: INEP, no 61, 1994. Pp. 1523.

BARCA, Isabel. O pensamento histórico dos jovens. Braga: Centro de Estudos em Educação e Psicologia - Instituto de Educação e Psicologia Universidade do Minho, 2000.

"Verdade e perspectivas do passado na explicação em História - Uma visão pós-desconstrucionista”. In: Revista O Estuda da História. Lisboa: APH, n³, 1998. Pp. 163173.

BAUDRILLARD, Jean. A sociedade de consumo. Lisboa, Portugal: Edições 70, 2007.

BAUMAN, Zygmunt. A sociedade individualizada. Rio de Janeiro: Jorge Zahar, 2008.

BERGMANN, Klaus. “A História na reflexão didática”. In: Revista Brasileira de História. São Paulo: FFLCH / USP, v. 9, nº 19, set. 89/ fev. 90. Pp. 31-42.

BITTENCOURT, Circe Maria Fernandes. "Disciplinas escolares: história e pesquisa". In: Oliveira, Marcus Aurélio Taborda de \& RANZI, Serlei Maria Fischer (orgs.). História das disciplinas escolares no Brasil: contribuições para o debate. Bragança Paulista, São Paulo: Universidade São Francisco, 2003. Pp.9-38.

BONNEWITZ, Patrice. Primeiras lições sobre a sociologia de P. Bourdieu. Petrópolis, Rio de Janeiro: Vozes, 2003.

BOSI, Ecléa. Memória e sociedade: lembranças de velhos. São Paulo: T. A. Queiroz, 1979. (Biblioteca de letras e ciências humanas).

BOURDIEU, Pierre. A economia das trocas simbólicas. 5a ed. São Paulo: Perspectiva, 2003. . "Esboço de uma teoria prática". In: ORTIZ, Renato. (org.). Pierre Bourdieu: sociologia. São Paulo: Ática, 1983. Pp. 46-81. (Coleção grandes cientistas sociais, $39)$. 
. "Gostos de classe e estilos de vida". In: ORTIZ, Renato. (org.). Pierre

Bourdieu: sociologia. São Paulo: Ática, 1983. Pp. 82-121. (Coleção grandes cientistas sociais, 39).

Escritos em educação. $3^{\mathrm{a}}$ ed. Petrópolis, Rio de Janeiro: Vozes, 2001.

. O poder simbólico. 4a ed. Rio de Janeiro: Bertrand Brasil, 2001.

BRANDÃO, Antonio Carlos \& DUARTE, Milton Fernandes. Movimentos Culturais de Juventude. São Paulo: Moderna, 1990. (Coleção polêmica).

BUENO, Belmira de Oliviera. "Entre a Antropologia e a História: uma perspectiva para a etnografia educacional”. In: Revista Perspectiva. Florianópolis: UFSC, v. 25, no 2 , jul. / dez. 2007. Pp. 471-501.

BURKE, Peter (org.). A escrita da história; novas perspectivas. São Paulo: UNESP, 1992. (Biblioteca básica).

Variedades de história cultural. Rio de Janeiro: Civilização Brasileira,

2000.

CASTORIADIS, Cornelius. A instituição imaginária da sociedade. $3^{\text {a }}$ ed. Rio de Janeiro: Paz e Terra, 1995. (Rumos da cultura moderna; v. 52).

CAVACO, Maria Helena. "Ofício do professor: o tempo e as mudanças". In: NÓVOA, António (org.). Profissão professor. 2a ed. Porto, Portugal: Porto, 1999. Pp. 155-191. (Colecção ciências da educação).

CERTEAU, Michel de. A invenção do cotidiano: 1 . artes de fazer. $5^{\text {a }}$ ed. Petrópolis: vozes, 2000 .

CHARTIER, Roger. A história cultural entre práticas e representações. Rio de Janeiro: Bertrand Brasil, 1990.

. "O mundo como representação". In: Revista Estudos Avançados. São

Paulo: Instituto de Estudos Avançados da USP, vol. 5, nํ11, 1991. Pp.173-191.

CHERVEL, André. "História das disciplinas escolares sobre um campo de pesquisa". In:

Teoria e educação, nº2. Porto Alegre: Pannonica, 1990. Pp.117-229.

CHIMÈNES, Myriam. “Musicologia e História. Fronteira ou 'terra de ninguém’ entre duas disciplinas?’. In: Revista de História. São Paulo: FFLCH / USP, n ${ }^{\circ}$ 157, $2^{\circ}$ semestre de 2007. Pp. 15-29.

CIAMPI, Helenice. "O professor de História e a produção dos saberes escolares: o lugar da memória”. In: FERREIRA, Antonio Celso; BEZERRA, Holien Gonçalves \& DE LUCA, Tania Regina (orgs.). O historiador e seu tempo. São Paulo: UNESP. 2008. Pp.203-221. 
CONTIER, Arnaldo Daraya. "Edu Lobo e Carlos Lyra: o nacional e o popular na canção de protesto (os anos 60)”. In: Revista de História. São Paulo: FFLCH/USP, v. 18, n 35, 1998. Pp. 13-52.

"Música no Brasil: história e interdisciplinaridade algumas interpretações (1926-80)". In: História em debate: problemas, temas e perspectivas. Anais do XVI Simpósio da Associação Nacional dos Professores de História. Rio de Janeiro: ANPUH, 22 a 26 de julho de 1991. Pp. 151-189.

CÓRDOVA, Rogério de Andrade. "Imaginário social e educação: criação e autonomia". In: Em Aberto. Brasília, nº 61, Pp. 24-44. 1994.

D’ ALÉSSIO, Márcia Mansour. "Memória: leituras de M. Halbwachs e P. Nora". In: Revista Brasileira de História. São Paulo: ANPUH / Marco Zero, vol. 13 n 25/26, setembro 92 / agosto 93. Pp. 97-103.

DENADAI, Erildo. "Reflexões docentes sobre o ensino de história por meio da música: um encontro com professores do sistema municipal de ensino de Vitória/ES”. Dissertação de mestrado. Vitória: Centro de Educação da Universidade Federal do Espírito Santo, 2006.

DOTTORI, Maurício. "De gêneros, de macacos e do ensino da composição musical". In: ILARI, Beatriz Senoi (org.). Em busca da mente musical: ensaios sobre os processos cognitivos em música - da percepção à produção. Curitiba: Ed. da UFPR, 2006. Pp. 145-161. DUARTE, Milton Joeri Fernandes. “A construção do conhecimento histórico dos movimentos político-culturais da década de 1960”. In: Revista História \& Ensino. Londrina: UEL, v. 13, 2007. Pp. 203-214.

Representações dos movimentos político-culturais da década de 60 nos jovens de ensino médio. Dissertação de mestrado. São Paulo: FEUSP, 2005. EZPELETA, Justa \& ROCKWELL, Elsie. Pesquisa participante. São Paulo: Cortez, 1986. (Coleção educação contemporânea).

FEATHERSTONE, Mike. A cultura de consumo e pós-modernismo. São Paulo: Studio Nobel, 1995.

(org.). Cultura global; nacionalismo, globalização e modernidade.

Petrópolis, Rio de Janeiro: Vozes, 1994.

FERREIRA, Martins. Como usar a música na sala de aula. São Paulo: Contexto, 2001. (Coleção como usar na sala de aula).

FERREIRA, Nilda Teves e EIZIRIK, Marisa Faermann. "Educação e imaginário social: revendo a escola". In: Em Aberto. Brasília: INEP, n 61, 1994. Pp. 5-14. 
FONTES, Virgínia. "História e modelos". In: CARDOSO, Ciro Flamarion e VAINFAS, Ronaldo (orgs.). Domínios da história. $5^{\text {a }}$ ed. Rio de Janeiro: Campus, 1997. Pp. 355-374.

FORQUIN, Jean-Claude. Escola e cultura: as bases sociais e epistemológicas do conhecimento escolar. Porto Alegre: Artemed, 1993.

"Saberes escolares, imperativos didáticos e dinâmicas sociais". In:

Teoria e Educação. Porto Alegre: Pannonica, nº 5, 1992. Pp.28-49.

FOUCAULT. Michel. Vigiar e punir - História da violência nas prisões. $5^{\mathrm{a}}$ ed. Petrópolis, Rio de Janeiro: Vozes, 1987.

FRAGO, Antonio Vinal. "Por uma historia de la cultura escolar: enfoques, cuestiones, fuentes". In: Culturas y civilizações / III Congresso de la Associación de Historia Contemporânea. Valladolid: Universidad de Vailladolid, 1996. Pp. 167-183.

GALZERANI, Maria Carolina Bovério. “A produção de saberes históricos escolares: o lugar das memórias”. In: FERREIRA, Antonio Celso; BEZERRA, Holien Gonçalves \& DE LUCA, Tania Regina (orgs.). O historiador e seu tempo. São Paulo: UNESP. 2008. Pp. 223-235.

GEERTZ, Clifford. A interpretação das culturas. Rio de Janeiro: LCT, 1989. (Coleção Antropologia social).

GODINHO, “O corpo na aprendizagem e na representação mental”. In: ILARI, Beatriz Senoi (org.). Em busca da mente musical: ensaios sobre os processos cognitivos em música - da percepção à produção. Curitiba: UFPR, 2006. Pp. 353-379.

GOFFMAN, Erving. A representação do eu na vida cotidiana. Petrópolis: Vozes, 1975. (Antropologia, 8).

GONZÁLEZ, Juan Pablo \& ROLLE, Claudio. "Escuchando el pasado: hacia una historia social de la música popular". In: Revista de História. São Paulo: FFLCH / USP, n ${ }^{\circ} 157,2^{\circ}$ semestre de 2007. Pp. 31-54.

GOODSON, Ivor. "La construcción social del currículum. Posibilidades y ámbitos de investigación de la historia del currículum”. In: Revista de Educación. Madrid: Centro de Publicaciones del Ministerio de Educación y Ciencia, no 295, 1991. Pp. 7-37.

"Dar voz ao professor: as histórias de vida dos professores e o seu desenvolvimento profissional". In: NÓVOA, Antonio (org.). Vidas de professores. $2^{\mathrm{a}}$ ed. Porto, Portugal: Porto, 1999. Pp. 63-78. (Colecção ciências da educação).

GUARRESCHI, Pedrinho \& JOVCHELOVITCH, Sandra. "Introdução". In: Ibid. (orgs.). Textos em representações sociais. Petrópolis, Rio de Janeiro: Vozes, 1999. Pp. 17-25.

HALBWACHS, Maurice. A memória coletiva. $2^{\mathrm{a}}$ Ed. São Paulo: Centauro, 2006. 
HALL, Stuart. A identidade cultural na pós-modernidade. $3^{\mathrm{a}}$ ed. Rio de Janeiro: DP \& A, 1999.

HAMELINE, Daniel. “O educador e a acção sensata". In: NÓVOA, António (org.). Profissão professor. $2^{a}$ ed. Porto, Portugal: Porto, 1999. Pp. 35-62. (Colecção ciências da educação).

HELLER, Agnes. Sociologia de la vida cotidiana. Barcelona: Península, 1977.

HOBSBAWM, Eric. Era dos extremos: o breve século XX (1914-1991). São Paulo: Cia. das Letras, 1995.

HOLLY, Mary Louise. "Investigando a vida profissional dos professores: diários biográficos". In: NÓVOA, Antonio (org.). Vidas de professores. $2^{\mathrm{a}}$ ed. Porto, Portugal: Porto, 1999. Pp. 79-110. (Colecção ciências da educação).

HUNT, Lynn (org.). A nova história cultural. São Paulo, Martins Fontes: 1992. (Coleção o homem e a história).

IGLESIAS, F. Javier Merchán. "El estudio de la clase de historia como campo de producción del currículo". In: Enseñanza de las Ciencias Sociales - Revista de investigación. Institut de Ciències de l' Universitat Autónoma de Barcelona - Institut de Ciències de l'Educació de la Universitat de Barcelona, $\mathrm{n}^{\mathrm{o}}$ 1, marzo de 2002. Pp. 41-54.

ILARI, Beatriz. "Música comportamento social e relações interpessoais. In: Psicologia em estudo. Maringá: UEM, v. 11, nº1, jan./abr., 2006. Pp. 191-198.

INRP. "Entrepise e representations: didactique de l'histoire, geographie et des sciences économique et sociales: um exemple de travail avec lés élèves”. Rencontres pédagogiques., Paris: INRP, $\mathrm{n}^{\mathrm{o}} 14,1989$. (Texto digitalizado, traduzido e adaptado por Circe Maria Fernandes Bittencourt).

JEANDOT, Nicole. Explorando o universo da música. 2a ed. São Paulo: Scipione, 2001. (Pensamento e ação no magistério).

JOSSO, Marie Christine. "As figuras de ligação nos relatos de formação: ligações formadoras, deformadoras e transformadoras. In: Revista Educação e Pesquisa. São Paulo: FEUSP, v. 32, $\mathrm{n}^{\mathrm{o}} 2$ 2, 2006. Pp. 373-383.

JOURDAIN, Robert. Música, cérebro e êxtase: como a música captura a sua imaginação. Rio de Janeiro: Objetiva, 1998.

LEE, Peter. “"Nós fabricamos carros e eles tinham que andar a pé": compreensão das pessoas do passado". In: BARCA, Isabel (org.). Educação histórica e museus. Braga: Centro de Estudos em Educação e Psicologia - Instituto de Educação e Psicologia Universidade do Minho, 2003. Pp. 19-36. 
LE GOFF, Jacques. História e memória. $5^{\mathrm{a}}$ ed. Campinas, SP: Editora da Unicamp, 2003. (org.). A história nova. $2^{\text {a }}$ ed. São Paulo: Martins Fontes, 1993. (O homem e a história).

LEVITIN, J. Daniel. A música no seu cérebro: a ciência de uma obsessão humana.rio de Janeiro: Civilização Brasileira, 2010.

LORAUX, Nicole. "Elogio do anacronismo". In: NOVAES, Adauto (org.). Tempo e História. São Paulo: Companhia das Letras, 1992. Pp. 57-70.

MADEIRA, Margot Campos. "Representações sociais: pressupostos e implicações". In: Revista Brasileira de Estudos Pedagógicos. Brasília: INEP, v. 72, nº171, 1991. Pp. 129-144. . "Um aprender do viver: educação e representação social". In:

MOREIRA, Antonia Silvia Paredes \& OLIVEIRA, Denize Cristina de (orgs.). Estudos interdisciplinares de representação social. $2^{\mathrm{a}}$ ed. Goiânia: AB, 2000. Pp. 239-250.

MARSON, Adalberto. "Reflexões sobre o procedimento histórico". In; SILVA, Marco A. Da Silva (org.). Repensando a história. Rio de Janeiro: Marco Zero / ANPUH, 1984. Pp. 37-64.

MELLO, Gláucia Boratto de. "Contribuições para o estudo do imaginário". In: Em Aberto. Brasília: INEP, no 61, 1991. Pp. 45-51.

MOITA, Maria da Conceição. "Percursos de formação e de trans-formação". In: NÓVOA, Antonio (org.). Vidas de professores. $2^{\mathrm{a}}$ ed. Porto, Portugal: Porto, 1999. Pp. 111-140. (Colecção ciências da educação).

MONTEIRO. Ana Maria. "Entre o estranho e o familiar: o uso de analogias no ensino de História. In: Cadernos do CEDES. Campinas: UNICAMP, v. 25, nº 67, set. /dez. 2005. Pp. 333-347.

MONTEIRO, Ana Maria. "A prática de ensino e a produção de saberes na escola". In: CANDAU, Vera Maria (org.). Didática, currículo e saberes escolares. $2^{\mathrm{a}}$ ed. Rio de Janeiro: DP\&A, 2001. Pp. 129-147.

MORAES, José Geraldo Vinci de. "História e música: canção popular e conhecimento histórico”. In: Revista de História. São Paulo: FFLCH / USP, v. 20, n 39, 2000. Pp. 203-221. . "Sons e música na oficina da História". In: Revista de História. São Paulo: FFLCH / USP, nº 157, $2^{\circ}$ semestre de 2007. Pp. 7-13.

MORAES, J. Jota de. O que é música. 2ª ed. São Paulo: Brasiliense, 1983.

MORIN, Edgar. Cultura de massas no século XX: o espírito do tempo I - neurose. $6^{\mathrm{a}}$ ed. Rio de Janeiro: Forense-Universitária, 1984.

Cultura de massas no século XX: o espírito do tempo II - necrose. $2^{\mathrm{a}}$ ed. Rio de Janeiro: Forense-Universitária, 1986. 
MOSCOVICI, Serge. Representações sociais: investigações em psicologia social. $3^{\mathrm{a}}$ ed. Petrópolis, Rio de Janeiro: Vozes, 2005.

MOITA, Maria da Conceição. "Percursos de formação e de trans-formação". In: NÓVOA, Antonio (org.). Vidas de professores. $2^{\mathrm{a}}$ ed. Porto, Portugal: Porto, 1999. Pp. 111-140.

MINAYO, Maria Cecília de Souza. "O conceito de representações sociais dentro da sociologia clássica". In: GUARESCHI, Pedrinho \& JOVCHELOVITCH (orgs.). Op. Cit. Pp. 113-186.

NAPOLITANO, Marcos \& Maria Clara Wasserman. "Desde que o samba é samba: a questão das origens no debate historiográfico sobre a música popular brasileira". In: Revista de História. São Paulo: FFLCH / USP, v. 20, nº 39, 2000. Pp. 167-189.

NAPOLITANO, Marcos. História e música - história cultural da música popular. Belo Horizonte: Autêntica, 2002. (Coleção história e reflexões).

. "História e música popular: um mapa de leituras e questões". In:

Revista de História. São Paulo: FFLCH / USP, n ${ }^{\circ} 157,2^{\circ}$ semestre de 2007. Pp. 153-171.

. Seguindo a canção: engajamento político e indústria cultural na MPB (1959-1969). São Paulo: Annablume / Fapesp, 2001.

NOGUEIRA, Maria Alice e CATANI, Afrânio (orgs.). Pierre Bourdieu - Escritos de educação. $3^{\mathrm{a}}$ ed. Petrópolis, Rio de Janeiro: Vozes, 1998.

NORA, Pierre. "Entre memória e história". In: Projeto História. São Paulo: PUC-SP, n 10, dezembro de 1993. Pp. 7-28.

NÒVOA, Antonio. "Prefácio à segunda edição". In: NÓVOA, António (org.). Profissão professor. $2^{\mathrm{a}}$ ed. Porto, Portugal: Porto, 1999.Pp. 7- 10. (Colecção ciências da educação).

. "Os professores e as histórias da sua vida". In: NÓVOA, Antonio

(org.). Vidas de professores. $2^{\mathrm{a}}$ ed. Porto, Portugal: Porto, 1999. Pp. 11-62. (Colecção ciências da educação).

ORDAZ, Olga \& VALA, Jorge. “Objetivação e ancoragem das representações sociais do suicídio na imprensa". In: MOREIRA, Antonia Silvia Paredes \& OLIVEIRA, Denize Cristina de (orgs.). Op. Cit. Pp. 87-114.

ORLANDI, Eni Puccinelli. "Discurso, imaginário social e conhecimento". In: Em Aberto. Brasília: INEP, n ${ }^{\circ}$ 61, 1994. Pp. 53-59.

ORTIZ, Renato. Cultura brasileira e identidade nacional. $2^{\mathrm{a}}$ ed. São Paulo: Brasiliense, 1986.

ORTIZ, Renato. A moderna tradição brasileira. $5^{\text {a }}$ ed. São Paulo: Brasiliense, 2001.

PALHEIROS, Graça Boal. "Funções e modos de ouvir música de crianças e adolescentes, em diferentes contextos”. In: ILARI, Beatriz Senoi (org.). Op. Cit.: Pp. 303-349. 
PAOLI, SÁDER E TELLES. "Pensando a classe operária: os trabalhadores sujeitos ao imaginário". In: Revista Brasileira de História. São Paulo: Marco Zero / ANPUH, nº 6, 1984. Pp. 129-149.

Parâmetros curriculares nacionais: arte. Secretaria de Educação Fundamental. Brasília: MEC / SEF, 1998.

PESAVENTO, Sandra Jatahy. "Em busca de uma outra história: imaginando o imaginário". In: Revista Brasileira de História. São Paulo, Contexto / ANPUH, vol. 15, n ${ }^{\circ}$ 29, 1995. Pp. 927.

PESAVENTO, Sandra Jatahy. História e história cultural. Belo Horizonte; Autêntica, 2003. (Coleção história e reflexões, 5).

PINTO, Tiago de Oliveira. "Som e música. Questões de uma antropologia sonora". In: Revista de Antropologia. São Paulo, v. 44, nº 01, 2001. Pp. 221-286.

POPKEWITZ, Thomas S. "História do currículo, regulação social e poder". In: SILVA, Tomaz Tadeu da (org.). O sujeito da educação - estudos foucaultianos. Petrópolis, Rio de Janeiro: Vozes, 1995. Pp.173-210.

POSTIC, Marcel. O imaginário na relação pedagógica. Rio de Janeiro: Jorge Zahar, 1993.

PRASS, Luciana. Saberes musicais em uma bateria de escola de samba: uma etnografia entre os Bambas da Orgia. Porto Alegre: UFRGS, 2004

QUEIROZ, Gregório J. Pereira de. A música compõem o homem, o homem compõem a música. São Paulo: Pensamento-Cultrix, 2000.

RANGEL, Mary. "Representação e leitura crítica do mundo nos livros didáticos". In: Em Aberto. Brasília: $\mathrm{n}^{\circ}$ 61, 1994. Pp. 177-185.

RUEDA, Carlos Velázquez. "Música: mais uma crônica da morte anunciada". In: Revista Humanidades. Fortaleza: Universidade de Fortaleza, v. 19, nº 2, jul./dez. 2004. Pp. 74-79.

RÜSEN, Jörn. "El desarrollo de la competência narrativa em el aprendizage histórico". In: Propuesta Educativa. Buenos Aires, año 4, nº 7, 1992. Pp. 27-37. . “A história entre a modernidade e a pós-modernidade". In: História: Questões e Debates. Curitiba, v. 14, nos 26/27, jan./dez., 1997. Pp. 80-101. . História viva - teoria da história: formas e funções do conhecimento histórico. Brasília: UNB, 2007. . Jörn Rüsen e o ensino de história. Curitiba: URPR, 2010. Razão histórica - teoria da história II: os princípios da pesquisa histórica. Brasília: UNB, 2001. 
Razão histórica - teoria da história III: fundamentos da ciência histórica.

Brasília: UNB, 2001.

SÁ, Celso Pereira de. Núcleo central das representações sociais. $2^{\mathrm{a}}$ ed. Petrópolis, Rio de Janeiro: Vozes, 2002.

SACRISTÁN, J. Gimeno. “Consciência e acção sobre a prática como libertação profissional dos professores”. In: NÓVOA, António (org.). Profissão professor. $2^{\mathrm{a}}$ ed. Porto, Portugal: Porto, 1999.Pp. 63-92.(Colecção ciências da educação).

O currículo: uma reflexão sobre a prática. $3^{\mathrm{a}}$ ed. Porto Alegre:

ArtMed, 2000.

SCHAFER, Raymond Murray. A afinação do mundo.São Paulo: UNESP, 1997.

. O ouvido pensante. São Paulo: UNESP, 1991.

SCHOPENHAUER, Arthur. "O mundo como vontade e representação”. In: Schopenhauer / Kierkegard. São Paulo: Abril Cultural, 1974. (Os Pensadores, vol. XXXI). Pp. 7-88.

SEKEFF, Maria de Lourdes. "Características psicològicas da música". In: Arte e Cultura III: estudos interdisciplinares. São Paulo: Annablume / Fapesp, 2004. Pp.27-37.

Da música, seus usos e recursos. $2^{\mathrm{a}}$ ed. São Paulo: UNESP,

2007.

. "Música e globalização". In: Arte e Cultura IV: estudos

interdisciplinares. São Paulo: Annablume / Fapesp, 2006. Pp.93-103.

SILVA, Marcos. "Cadência, decadência, recadência: o tropicalismo e o samba-fênix". In: Revista de História. São Paulo: FFLCH / USP, n ${ }^{\circ} 157,2^{\circ}$ semestre de 2007. Pp. 229-236.

"Sons de História". In: Entre passado e futuro - revista de História

Contemporânea. São Paulo: Grupo de Pesquisa História e Economia Mundial Contemporâneas - CNPq, nº 2, setembro de 2002. Pp.104-126.

SILVA, Marcos \& FONSECA, Selva Guimarães. Ensinar História no século XXI: em busca do tempo entendido. Campinas, São Paulo: Papirus, 2007.

SNYDERS, Georges. A escola pode ensinar as alegrias da música? $3^{\mathrm{a}}$ ed. São Paulo: Cortez, 1997.

SOBRINHO, Moisés Domingos. “'Habitus' e representações sociais: questões para o estudo de identidades coletivas". In: MOREIRA, Antonia Silvia Paredes \& OLIVEIRA,

Denize Cristina de (orgs.). Op. Cit. Pp. 117-130.

STEFANI, Gino. Para entender a música. Rio de Janeiro: Globo, 1987.

SWANWICK, Keith. Ensinando música musicalmente. São Paulo: Moderna, 2003. 
TARDIF, Maurice. “Os professores enquanto sujeitos do conhecimento: subjetividade, prática e saberes no magistério". In: CANDAU, Vera Maria (org.). Didática, currículo e saberes escolares. $2^{\mathrm{a}}$ ed. Rio de Janeiro: DP\&A, 2001. Pp. 112-128. . Saberes docentes e formação profissional. $6^{\mathrm{a}}$ ed. Petrópolis, Rio de Janeiro: Vozes, 2006.

TERRA, Antonia. "História e dialogismo". In: BITTENCOURT, Circe (org.). O saber histórico na sala de aula. $2^{\mathrm{a}}$ ed. São Paulo: Contexto, 1998. Pp. 91-103. (Repensando o ensino).

TEVES, Nilda e RANGEL, Mary (orgs.). Representação social e educação. São Paulo: Papirus, 1999. (Magistério: formação e trabalho pedagógico).

TOMÁS, Lia. Ouvir o lógos: música e filosofia. São Paulo: UNESP, 2002.

TRAVASSOS, Elizabeth. "Tradição oral e História”. In: Revista Brasileira de História. São Paulo: FFLCH / USP, $n^{\circ} 157,2^{\circ}$ semestre de 2007. Pp. 129-152.

VAINFAS, Ronaldo. "História das mentalidades e história cultural". In: CARDOSO, Ciro Flamarion e VAINFAS, Ronaldo (orgs.). Domínios da história. $5^{\mathrm{a}}$ ed. Rio de Janeiro: Campus, 1997. Pp. 127-162.

VESENTINI, Carlos Alberto. "Escola e livro didático de História”. In; SILVA, Marco A. Da Silva (org.). Repensando a história. Rio de Janeiro: Marco Zero / ANPUH, 1984. Pp. 69-80.

A teia do fato: uma proposta de estudo sobre a memória histórica . São Paulo: Hucitec / História Social, USP, 1997.

VOVELLE, Michel. Ideologias e mentalidades. São Paulo: Brasiliense, 1987. Imagens e imaginário na história - Fantasmas e certezas nas mentalidades desde a Idade Média até o século XX. São Paulo: Ática, 1997. (Série terras, vol. 42).

VYGOTSKY, L. S. Pensamento e linguagem. $2^{\text {a }}$ ed. São Paulo: Martins Fontes, 1989. WAZLAWICK, Patrícia. "Quando a música entra em ressonância com as emoções, significados e sentidos na narrativa de jovens estudantes de musicoterapia”. In: Revista Científica / FAP - Versão Eletrônica. Curitiba: Faculdade de Artes do Paraná, v. 1, Janeiro Dezembro de 2006. (http://www1.fapr.br/Revista/).

WEBER, Max. Os fundamentos racionais da música. São Paulo: Edusp, 1995.

WHITROW, G. J. O Tempo na história: concepções sobre o tempo da pré-história aos nossos dias. Rio de Janeiro: Jorge Zahar, 1993. (Ciência cultura).

WISNIK, José Miguel. "Entre o erudito e o popular”. In: Revista de História. São Paulo: FFLCH / USP, $n^{\circ} 157,2^{\circ}$ semestre de 2007. Pp. 55-72. 
ZAMBONI, Ernesta. "Representações e linguagens no ensino de história". In: Revista Brasileira de História. São Paulo: Contexto / ANPUH, vol. 18, nº 36, 1998. Pp. 89-101. 


\section{PÁGINAS ELETRÔNICAS}

http://cliquemusic.uol.com.br/

http://jovempan.uol.com.br

http://letras.terra.com.br

http://www.orkut.com 